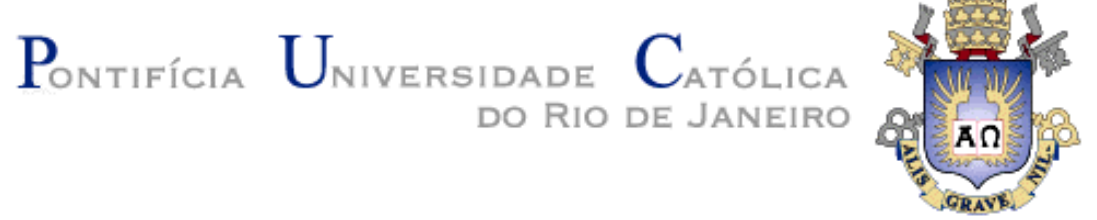

Valesca Quadrio Veiga da Silva

\title{
Matéria transfigurada: a experimentação expressiva de Oswaldo Goeldi
}

\author{
Dissertação de Mestrado
}

\begin{abstract}
Dissertação apresentada ao Programa de Pós-Graduação em História Social da Cultura do Departamento de História da PUC-Rio como parte dos requisitos para obtenção do grau de Mestre em História Social da Cultura.
\end{abstract}

Orientador: Prof. Ronaldo Brito Fernandes

Rio de Janeiro

Dezembro de 2017 


\title{
Pontifícia U Universidade Católica $_{\text {a }}$

\section{Valesca Quadrio Veiga da Silva}

\section{Matéria transfigurada: a experimentação expressiva de Oswaldo Goeldi}

Dissertação apresentada como requisito parcial para obtenção do grau de Mestre pelo Programa de PósGraduação em História Social da Cultura do Departamento de História do Centro de Ciências Sociais da PUC-Rio. Aprovada pela Comissão Examinadora abaixo assinada.

\author{
Prof. Ronaldo Brito Fernandes \\ Orientador \\ Departamento de História - PUC-Rio \\ Profa Vera Beatriz Cordeiro Siqueira \\ Instituto de Artes - UERJ
}

Prof. Antonio Edmilson Martins Rodrigues

Departamento de História - PUC-Rio

Prof. Augusto César Pinheiro da Silva

Vice-Decano de Pós-Graduação do Centro de Ciências Sociais - PUC-Rio

Rio de Janeiro, 05 de dezembro de 2017. 
Todos os direitos reservados. É proibida a reprodução total ou parcial do trabalho sem autorização da universidade, da autora e do orientador.

\section{Valesca Quadrio Veiga da Silva}

Graduada em Jornalismo pela PUC-Rio, em 1994, cursou Especialização em História da Arte e da Arquitetura no Brasil nesta mesma instituição, entre 2011 e 2013. Trabalhou durante 15 anos como jornalista e produtora gráfica em empresas de comunicação e editoras nacionais e estrangeiras. Atualmente, é artista plástica, produtora de conteúdo relacionado à arte e cultura e pesquisadora independente em arte moderna e contemporânea.

Ficha Catalográfica

Silva, Valesca Quadrio Veiga da

Matéria transfigurada : a experimentação expressiva de Oswaldo Goeldi / Valesca Quadrio Veiga da Silva ; orientador: Ronaldo Brito Fernandes. - 2017.

107 f. : il. color. ; $30 \mathrm{~cm}$

Dissertação (mestrado)-Pontifícia Universidade Católica do Rio de Janeiro, Departamento de História, 2017.

Inclui bibliografia

1. História - Teses. 2. História Social da Cultura - Teses. 3. Arte. 4. Arte moderna. 5. Expressionismo. 6. Xilogravura. 7. Oswaldo Goeldi. I. Fernandes, Ronaldo Brito. II. Pontifícia Universidade Católica do Rio de Janeiro. Departamento de História. III. Título.

CDD: 900 


\section{Agradecimentos}

Ao Prof. Ronaldo Brito pela dedicada orientação;

À Prof ${ }^{\mathrm{a}}$. Vera Beatriz Siqueira e Prof. Antônio Edmilson Martins Rodrigues pela estimada participação na banca examinadora;

À CAPES, pelo apoio através da bolsa de estudos ao longo do curso;

A todo o Departamento de História da PUC-Rio, especialmente à Edna Timbó, Cláudio Santiago e Prof ${ }^{\mathrm{a}}$. Rejane Augusto de Mattos;

À Prof ${ }^{\mathrm{a}}$. Cecília Cotrim por ter me apresentado Oswaldo Goeldi;

Ao Dr. Jair de Carvalho e Castro por abrir sua coleção a esta pesquisa;

À curadora Laura Maria Neves de Abreu e à equipe de reserva do Museu Nacional de Belas Artes pelo acesso ao acervo de xilogravuras e matrizes;

A Gustavo Gonçalves e Patrícia Lattavo por suas colaborações com o texto. 


\section{Resumo}

Silva; Valesca Quadrio Veiga da; Fernandes, Ronaldo Brito. Matéria transfigurada: a experimentação expressiva de Oswaldo Goeldi. Rio de Janeiro, 2017. 107p. Dissertação de Mestrado - Departamento de História, Pontifícia Universidade Católica do Rio de Janeiro.

Por meio da construção singular de um rigoroso processo técnicoartesanal, as xilogravuras de Oswaldo Goeldi adquiriram potência expressiva autônoma em sua totalidade, desde a elaboração da matriz à impressão final das obras, tendo a constante experimentação como fator decisivo. A experiência cromática assumiu força comunicativa quando se despojou de atributos decorativos e se apresentou como elemento gráfico preciso, complementando o sistema expressivo goeldiano. Certa obscuridade crítica manteve Goeldi em posição lateral em relação ao movimento modernista, até que apropriações e revisões historiográficas contemporâneas de sua obra reafirmassem a importância de sua poética moderna única na arte brasileira da primeira metade do século XX.

\section{Palavras-chave}

Arte; Arte moderna; Expressionismo; Xilogravura; Oswaldo Goeldi. 


\section{Abstract}

Silva; Valesca Quadrio Veiga da; Fernandes, Ronaldo Brito. (Advisor). Transfigured matter: the expressive experimentation of Oswaldo Goeldi. Rio de Janeiro, 2017. 107p. Dissertação de Mestrado Departamento de História, Pontifícia Universidade Católica do Rio de Janeiro.

By means of a singular construction of rigorous technical-craft process, the woodcuts of Oswaldo Goeldi acquired expressive autonomous potentiality, from the elaboration of the engraved woodblock to the final printing, having constant experimentation as decisive factor. Chromatic experience gained communicative strength when it got rid of ornamental features and revealed itself as precise graphic element, complementing the goeldian expressive system. A certain critical obscurity kept Goeldi in a border position in relation to the modernist movement until contemporary appropriations and historiographic reviews of his work reaffirmed the importance of his unique modern poetic in Brazilian art of the first half of the 20th century.

\section{Keywords}

Art; Modern Art; Expressionism; Woodcut; Oswaldo Goeldi. 


\section{Sumário}

1. Introdução 12

2. O caminho da expressão 19

2.1. Matrizes modernas $\quad 19$

2.2. A xilogravura: matéria e técnica expressivas 34

2.3. A experimentação cromática 48

3. Imensidão íntima 60

3.1. Casa e refúgio 60

3.2. Infância e natureza $\quad 67$

3.3. Águas $\quad 71$

3.4. Cidade e morte $\quad 78$

4. Conclusão $\quad 88$

5. Referências bibliográficas 102 


\section{Lista de figuras}

Figura 1: ENSOR, JAMES. Morte perseguindo o rebanho dos mortais, 189623

Figura 2: GOYA, FRANCISCO. Disparate do medo, 1824

Figura 3: MUNCH, EDVARD. A tempestade, 1908-1909 24

Figura 4: ENSOR, JAMES. Preguiça, $1902 \quad 24$

Figura 5: KUBIN, ALFRED. O horror, 1912

Figura 6: KLINGER, MAX. Praga, $1903 \quad 28$

Figura 7: KUBIN, ALFRED. Homem, 1902

Figura 8: GAUGUIN, PAUL. Maruru de Noa, Noa, 1893-1894 31

Figura 9: GAUGUIN, PAUL. Cabeça de chifre, 1893-1894 31

Figura 10: GOELDI, OSWALDO. Sem título, s/d 32

Figura 11: BECKHAMM, MAX. Autorretrato, 1922

Figura 12: VAN GOGH, VINCENT. Bétulas podadas, 1884

Figura 13: HECKEL, ERICH. Stralsund, 1912

Figura 14: ROTTLUFF, KARL-SCHMIDT. Nas redes, 1914

Figura 15: GOELDI, OSWALDO. Vista urbana, 1930

Figura 16: GOELDI, OSWALDO. Paisagem noturna, 1930

Figura 17: GOELDI, OSWALDO. Sem título (Paisagem noturna), $1951 \quad 38$

Figura 18: GOELDI, OSWALDO. Luz sobre a praça, 1949

Figura 19: GOELDI, OSWALDO. Luz sobre a praça, 1949

Figura 20: GOELDI, OSWALDO. Chuva de vento ou Ventania, s.d 41

Figura 21: VAN GOGH, VINCENT. Corvos sobre o trigal, 1890

Figura 22: MUNCH, E. Primavera na Floresta Elm, 1923

Figura 23: GOELDI, OSWALDO. Uiara, Ilustração para Cobra Norato, 193749

Figura 24: GOELDI, OSWALDO. Onça, llustração para Cobra Norato, 193749

Figura 25: VAN GOGH, VINCENT. O salão de dança em Arles, 1888

Figura 26: GAUGUIN, PAUL. O Cristo Amarelo, 1889

Figura 27: MUNCH, EDVARD. Separação, 1896

Figura 28: MUNCH, EDVARD. Dois seres humanos, dois solitários, $1899 \quad 54$

Figura 29: MUNCH, EDVARD. Morte no quarto do doente, 1896

Figura 30: GOELDI, OSWALDO. Tarde, 1954

Figura 31: GOELDI, OSWALDO. Sem título (Siri), 1955

Figura 32: GOELDI, OSWALDO. Sol vermelho, 1957 
Figura 33: GOELDI, OSWALDO. Sol Vermelho, 1955

Figura 34: GOELDI, OSWALDO. Chuva, 1955

Figura 35: GOELDI, OSWALDO. Chuva, 1955

Figura 36: GOELDI, OSWALDO. Jardim Tropical, circa 1930

Figura 37: GOELDI, OSWALDO. Noturno, $1950 \quad 62$

Figura 38: GOELDI, OSWALDO. Silêncio, 1957

Figura 39: GOELDI, OSWALDO. Pescadores, 1955

Figura 40: GOELDI, OSWALDO. Nuvens pretas, 1953

Figura 41: GOELDI, OSWALDO. Crepúsculo, 1957

Figura 42: GOELDI, OSWALDO. (Ameaça de chuva), 1945

Figura 43: GOELDI, OSWALDO. Sem título, 1950

Figura 44: GOELDI, OSWALDO. Rua molhada, 1937

Figura 45: GOELDI, OSWALDO. A morte do guarda-chuva, 1937

Figura 46: GOELDI, OSWALDO. Urubus, circa 1929

Figura 47: GOELDI, OSWALDO. Baiana, 1941

Figura 48: GOELDI, OSWALDO. Ilustração para Recordação da casa dos mortos, 1941

Figura 49: SEGALL, LASAR. Visões de Guerra, 1941-1943 86

Figura 50: SEGALL, LASAR. Visões de Guerra, 1941-1943 86

Figura 51: GOELDI, OSWALDO.167 de uma só vez 87

Figura 52: PAPE, LYGIA. Tecelar, 1955

Figura 53: PAPE, LYGIA. Tecelar, 1957

Figura 54: RAMOS, NUNO. Esculturas. Para Goeldi 1, 1996

Figura 55: RAMOS, NUNO. Cópias de xilogravuras com intervenção de fumaça. Para Goeldi 1, $1996 \quad 96$

Figura 56: RAMOS, NUNO. Para Goeldi 2, 2000

Figura 57: RAMOS, NUNO. Mocambos: Para Goeldi 3, 2003

Figura 58: RAMOS, NUNO. Silêncio: Para Goeldi 4, 2008

Figura 59: RAMOS, NUNO. Bandeira Branca, $2008 \quad 98$

Figura 60: RAMOS, NUNO. Bandeira branca, $2008 \quad 98$

Figura 61: RAMOS, NUNO. Marémobília, $2000 \quad 99$

Figura 62: RAMOS, NUNO. Marémobília, 2000 
"O vento varria tudo! E a minha vida ficava Cada vez mais cheia

De tudo."

Manuel Bandeira

\footnotetext{
${ }^{1}$ BANDEIRA, Manuel. Canção do vento e da minha vida. Lira dos Cinquent'anos.
} 


\section{1. Introdução}

"Expressar não foi para ele um verbo qualquer, de sentido imediato,
mas a ação que melhor definiu as origens,
a natureza, a ambição, a gravidade intrínseca
de sua arte".

Carlos Drummond de Andrade

A leitura de imagens por meio do enquadramento de gêneros e estilos sempre compôs a lógica interna da história da arte desde sua consolidação como disciplina de conhecimento, a partir da segunda metade do século XVIII. Em Prefácio à História da Arte Antiga, de 1764, J.J. Winckelmann delineia as diretrizes necessárias ao historiador através de estudo aprofundado da arte e de minuciosa observação da obra para reunir as condições de "bem julgar" as produções artísticas:

"Uma história da arte deve remontar até a sua origem, seguindo seus progressos e mudanças, até sua decadência e seu fim. Ela deve dar a conhecer o estilo diferente dos povos, dos tempos, e dos artistas, atribuir-lhe as características e o justificar, sempre que possível, por meio de obras que ainda existam. Pois o resto não passa de conjectura. ${ }^{3 "}$

Em uma configuração definida por molduras cronológicas, geográficas e culturais, que partiam de uma perspectiva eurocêntrica, o conceito idealizado de história da arte era a própria narrativa do sentido de universalidade. Paradoxalmente, o fundamento da ciência da arte surgia na modernidade procurando seu objeto de estudo no passado. O teórico da arte Hans Belting, apesar de reconhecer certa analogia entre o olhar dos artistas e dos historiadores da arte moderna, observa que os primeiros revelavam em suas obras a mesma visão de seus contemporâneos, enquanto os estudiosos a dirigiam para a arte pregressa:

\footnotetext{
2 ANDRADE, Carlos Drummond de. Goeldi e espanto, Correio da Manhã, Rio de Janeiro, 04/10/1956.

${ }^{3}$ WINCKELMANN, Joham Joachim. Préface. In Histoire de l'Art chez les Anciens, tome I. Yverdon: 1784. P.V-XXXIV. Tradução: Daniela Kern. P.1.
} 
"De maneira obstinada e quase paradoxal, o projeto da antiga história da arte está associado ao projeto da modernidade. No par conceitual da história e estilo é dada a conhecer a verdadeira fisionomia da modernidade, à qual hoje se repreende por ter possuído uma imagem unilateral da história e uma vontade de estilo tirânica que não podia ser contestada. ${ }^{4}$,

Quando nos dias atuais observamos a arte moderna em relação à produção contemporânea, com toda a complexidade e problemática desta análise, a pretensa filosofia universal reivindicada pela modernidade nos parece mais uma visão elitista que não atingiu a propagação mundial inicialmente pretendida. $\mathrm{O}$ gênero artístico, que sempre se mostrou como enquadramento, submetendo o observador à posição passiva, deixou de ter função com a transformação do objeto, rompendo com a legitimidade do "correto" estilo de arte que definia padrões de identificação ou contestação no meio social. Desafios pelos quais tanto se lutou no passado perderam significado diante da realidade de um sistema de arte regido por relações de "mercado", como a provocação moderna à cultura burguesa por meio de movimentos anti-burgueses ou o discurso de libertação de tabus sociais. A história se tornou acessível e "onipresente", perdendo soberania como lugar de identidade ou contradição. Na arte contemporânea, a dissolução da imagem e do discurso focado na produção individual, juntamente com a fugacidade na duração da percepção, transformam a relação sujeito/obra e obrigam a história da arte a se reposicionar já que todos os estilos passam a ser admitidos lado a lado:

\begin{abstract}
"Como realização cultural, o enquadramento tinha uma importância tão grande quanto a própria arte que ele capturava. Somente o enquadramento fundia em imagem tudo o que ela continha. Somente a história da arte emoldurava a arte legada na imagem em que aprendemos a vê-la. Somente o enquadramento instituía o nexo interno da imagem. A era da história da arte coincide com a arte do museu, já que eram reunidos e dispostos apenas trabalhos que já estivessem inseridos nesta história da arte."
\end{abstract}

Em sua análise sobre a relação entre a vanguarda histórica na arte moderna e os movimentos contemporâneos de neovanguarda, nas décadas de 1950 e 1960, o crítico Hal Foster considerou dois princípios fundantes de sua tese: os conceitos de "paralaxe"6 e "a posteriori". Na ideia de paralaxe, elaborações sobre o passado

\footnotetext{
${ }^{4}$ BELTING, Hans. O fim da história da arte: uma revisão dez anos depois. P.64

${ }^{5}$ BELTING, Hans. O fim da história da arte: uma revisão dez anos depois. P.35.

${ }^{6}$ A palavra Paralaxe tem sua origem no idioma grego e significa alteração. Na astronomia, o termo corresponde à alteração da posição angular que ocorre entre dois pontos estacionários relativos quando vistos por um observador em movimento. Isto significa que ocorre uma aparente alteração em relação à posição de um objeto quando um observador varia o fundo de observação.
} 
dependem de nossas posições no presente, e vice-versa, de forma que o olhar muda de acordo com o ponto de vista histórico e temporal. Oriunda da psicanálise, a concepção a posteriori afirma que um evento só pode ser classificado como traumático quando um outro posterior o recodificar retroativamente. Por meio da combinação dos dois efeitos, Foster conclui que vanguarda e neovanguarda agiram uma sobre a outra em paralaxe e que só o efeito a posteriori pôde desenvolver efetivamente o projeto de vanguarda em plenitude. "Uma vez parcialmente reprimida, a vanguarda volta e continuará voltando, mas volta do futuro (paralaxe) e essa é a sua temporalidade paradoxal"7.

Quando nos propomos a analisar a obra de Oswaldo Goeldi, sessenta e seis anos após sua premiação na $1^{\mathrm{a}}$ Bienal de São Paulo, o primeiro reconhecimento de relevância que recebeu no meio de arte nacional, nos deparamos com inúmeras dificuldades que perpassam questões que acabamos de abordar. O olhar comprometido com a contemporaneidade suspeita da necessidade histórica do enquadramento em lidar com as referências do moderno. Ao se classificar obras em categorias, condizentes com linhas do tempo e dos meios, oprimimos, a nosso ver, a amplitude de imersão na inquirição do objeto em si. Observar o artista mais livremente, sem rótulos, seria um dos caminhos mais eficientes para a captação sutil da essência comunicativa de sua obra, justamente por estarmos analisando a poética de um artista único na arte moderna brasileira da primeira metade do século XX.

Situar Goeldi no contexto do movimento expressionista é, por si só, uma escolha complexa se levamos em consideração não apenas a amplitude obrigatória à efetiva contextualização desta vertente histórica, como também o fato da própria noção de expressão ter sido absorvida, tanto no universo da arte como no senso comum, pela ideia de expressividade pessoal se estendendo a artistas de todos os estilos e segmentos culturais. Contudo, entender o caminho expressivo percorrido pelo artista tornou-se imprescindível à compreensão sobre a ascensão de sua poética, seu lugar ou falta de lugar na modernidade brasileira e, consequentemente, a atualidade de sua obra. Optamos, assim, por um recorte histórico que privilegiou influências e referências estéticas mencionadas pelo

\footnotetext{
${ }^{7}$ FOSTER, Hal. O retorno do real: a vanguarda no final do século XX. P.48.
} 
próprio artista, bem como outras notórias consideradas por estudiosos, teóricos e críticos de arte. O curioso é que, com o tempo, a própria obra se afastou de estilos e ressonâncias europeias, tornando-se substancialmente original, peculiar e desassociada do que se legitimava como artes visuais no Brasil nas primeiras décadas dos anos 1900.

No primeiro capítulo, traçamos a trajetória expressiva de Goeldi nos aproximando de repercussões que artistas como Edvard Munch, Vincent Van Gogh, James Ensor, Francisco Goya e membros das correntes expressionistas alemãs exerceram sobre a obra goeldiana, principalmente o contato com o artista austríaco Alfred Kubin. A partir do encontro com a obra kubiniana, em 1917, Goeldi vislumbra novas possibilidades expressivas muito próximas de suas intuições românticas. Kubin torna-se sua principal referência e o mais importante incentivador de sua obra: a correspondência entre ambos perdurou por 25 anos. Apesar de ter encontrado “o espírito" que correspondia ao $\mathrm{seu}^{8}$, sua poética singular se consolidaria em terras brasileiras, acabando por afastá-lo do visionarismo simbolista de seu mentor.

Em uma quase unanimidade sobre o papel de Goeldi como artista inteiramente moderno, críticos e historiadores convergem quanto à autenticidade de sua estética expressionista tardia e do seu ethos romântico. Contudo, algumas das condições românticas presentes em Goeldi - o desprezo pelo progresso material e técnico, característicos do mundo moderno, a introspecção própria a uma concepção de trabalho singular e a devoção intensa a um ideal de vida e obra - entravam em contradição com a função de ilustrador de jornais e revistas, principais meios de comunicação de massa da época. A escolha da xilogravura será analisada aqui através da ótica da ambiguidade entre reprodução técnica, que abole a ideia de obra única, e os ideais românticos contrários ao racionalismo progressista que favorece a reprodutibilidade.

A partir da descoberta da xilogravura, a construção meticulosa de um rigoroso processo técnico-artesanal adquiriu potência expressiva em sua totalidade, desde a escolha da peça da madeira à impressão e reprodução dos

\footnotetext{
${ }^{8}$ Entrevista de Oswaldo Goeldi a Ferreira Gullar. Suplemento Dominical do Jornal do Brasil, em 12/01/1957. In: BRITO, Ronaldo. Oswaldo Goeldi. Coordenação de Silvia Roesler. Pg. 210.
} 
trabalhos. A experimentação cromática, aperfeiçoada por décadas de desmedida dedicação, assumiu papel expressivo quando se despojou de atributos decorativos e encontrou na cor o elemento gráfico que complementa o sistema goeldiano. "Foi uma luta árdua chegar ao colorido sem perder o sentido gráfico"9, já avaliava Goeldi em carta a Kubin de 1950, quando nem sequer havia produzido algumas de suas obras-primas policrômicas, como Chuva (Fig. 34) e Sol Vermelho (Fig. 32), coroando anos de pesquisa cromática. Procuramos esmiuçar esta sistematização criativa nas relações entre matéria e imaginação do artista, nos valendo em especial das teorias psico-filosóficas de Gaston Bachelard (1884-1962).

Contemporâneo de Goeldi, Bachelard construiu original percurso como pensador. Instaurou o discurso epistemológico autônomo na França da década de 1930, propondo uma linha alternativa ao neopositivismo lógico, levando à reflexão sobre a relação intrínseca entre história e ciência. Ao mesmo tempo em que circulava pelos meandros do pensamento científico, aspirava abarcar os sonhos e a imaginação do homem, extrapolando os limites da argumentação filosófica por outras áreas do saber como psicologia, história, estética, crítica literária, pedagogia e ciências físico-químicas. Racionalista, refutou, entretanto, hipóteses fundamentais da tradição no desenvolvimento de filosofia não aristotélica, cartesiana, kantiana ou bergsoniana ${ }^{10}$. O seu pensamento apresenta fratura intrigante ao se desenvolver por duas vertentes bastante antagônicas: ciência e poética. Como racionalista moderno, propôs a epistemologia adequada ao novo espírito científico da época. Admirador da arte e da poesia, buscou o sentido da imagem e da imaginação fora do conceito de mímesis da tradição. A complementaridade entre os dois caminhos, a princípio díspares, é a possibilidade de formação do ser integral em sua construção filosófica. Em Bachelard, tanto como em Goeldi, a elaboração desta plenitude do ser surge por caminhos dicotômicos: ciência-poesia para o filósofo, técnica-imaginação para o artista.

Bachelard admite certa cooperação da psicanálise para dominar o fenômeno humano, sendo necessário compreender a fenomenologia da imagem para dela

\footnotetext{
${ }^{9}$ Carta de Goeldi a Kubin, 15/12/1950. In: RIBEIRO, Noemi. Oswaldo Goeldi: um autorretrato. P. 178.

${ }_{10}$ BARBOSA, Elyana; BULCÃO, Marly. Bachelard: pedagogia da razão, pedagogia da imaginação. P.13.
} 
obter eficácia psicanalítica. O psicanalista não deve permanecer na superficialidade das metáforas e comparações, o fenomenólogo deve chegar ao extremo das imagens. A psicologia da imaginação e do devaneio analisa as imagens anteriores à consciência, que seguem ao mesmo tempo as forças da natureza e nossa essência, que tomam a matéria e o movimento dos elementos ativos em nós mesmos. Nas teorias da imaginação material, encontramos conexões produtivas entre as descrições psico-filosóficas de Bachelard e o processo criativo de Goeldi.

No segundo capítulo, aprofundamos a análise dos signos da imensidão íntima expressiva do artista como ferramenta de desdobramento crítico de sua obra. No cerne da temática goeldiana está o universo urbano traduzido em linguagem plástica através de símbolos e referências próprias. A tragicidade da cidade moderna, revelada na pulsação de suas angústias pela representação de ruas abandonadas, casarios fantasmagóricos, excluídos sociais, e toda uma gama de lirismo na simbologia das águas do mar e da chuva, na comunhão com a natureza como única alternativa aos males do mundo. Consideramos que, na fenomenologia bachelardiana, as relações entre poesia e poetas estão para o devaneio e as lembranças, assim como no processo criativo de Goeldi os meios expressivos estão para a imaginação e a memória. Tais analogias psico-filosóficas, que nos permitimos neste trabalho, corroboraram e tornaram ainda mais visível a situação de escuridão a que Goeldi permaneceu submetido por anos em nossa história da arte, em uma quase total falta de conexão com o pensamento dominante no meio cultural brasileiro até a metade do século XX, salvo raras exceções.

Certa obscuridade ambígua também permeia a bibliografia crítica do artista para além das composições em negativo de suas xilogravuras. Considerado o primeiro artista moderno estrito da arte brasileira por historiadores e críticos, passando à margem do projeto modernista de construção da identidade nacional, Goeldi também é visto como um ilustrador-gravador que se beneficiou dos meios de comunicação de massa. Propomos uma reflexão sobre o posicionamento do artista na história da arte concluindo nossa pesquisa com a atualidade de seu trabalho pela análise em paralaxe e pelo efeito a posteriori de apropriações de 
artistas como Lygia Pape, nos anos 1950 e 1970, e Nuno Ramos, a partir da década de 1990, através de outras linguagens como o cinema e a instalação, e da intensa retomada do gravador como objeto de estudo principalmente a partir das celebrações do centenário de seu nascimento. O impulso imaginativo aliado ao "fazer" goeldiano como possível concepção de gestualidade expressiva, como aconteceu de certa forma na Die Brücke, ampliou o alcance de inspiração da obra de Oswaldo Goeldi para artistas de várias gerações. $\mathrm{O}$ artesanal foi muito além de simples meio de comunicação: um sistema de experiência expressiva autônoma levado à risca e ao risco. 


\section{2. \\ O caminho da expressão}

2.1.

Matrizes modernas
"O artista, a meu ver, tem que descobrir por si mesmo tudo o que servirá a sua expressão porque essa necessidade de expressão é o que o fará descobrir os valores da gravura, e tudo o que vier de fora ou é desnecessário ou prejudicial. “ 11

Oswaldo Goeldi

Em sua autobiografia, o artista expressionista Emil Nolde expôs sua inquietude quanto à representação mimética do real, principal contestação da arte moderna. O modo como desenhava e pintava imitando e dando forma à natureza era tão insuficiente às aspirações plásticas do espírito que, na tentativa de encontrar "algo diferente, mais profundo, a essência mesma das coisas"12, rabiscava e apagava o papel várias vezes até enchê-lo de buracos. Inserido na concepção romântica de valorização do Eu, Nolde, assim como Goeldi, não considerava mais a arte uma modalidade de conhecimento exercida sobre o naturalismo, tampouco se entusiasmava com as técnicas impressionistas que julgava serem um "caminho já trilhado":

“A imitação fiel e exata da natureza, não cria uma obra de arte. (...) A reavaliação dos valores da natureza, acrescida da espiritualidade de cada um, possibilita a transformação do trabalho em obra de arte. Eu perseguia tais sensações e por vezes me via diante da natureza cinzenta, tão simples e que, não obstante, pode ser tão profusamente rica quando animada pelo sol, pelo vento e pelas nuvens. "13

A formação intelectual de Goeldi aconteceu na Suíça nas duas primeiras décadas do século $\mathrm{XX}$, quando o meio artístico europeu era sacudido pela efervescência dos movimentos modernos de vanguarda. As vertentes de ruptura nas artes visuais representavam a culminância das transformações do pensamento estético europeu que se processaram no século anterior. Em oposição às restrições

\footnotetext{
${ }^{11}$ Entrevista de Oswaldo Goeldi a Ferreira Gullar. Suplemento Dominical do Jornal do Brasil, em 12/01/1957. In: BRITO, Ronaldo. Oswaldo Goeldi. Coordenação de Silvia Roesler. Pg. 209.

${ }^{12}$ NOLDE, Emil. Emil Nolde, anos de luta. In: Chipp, H.B. As teorias da arte moderna. Rio de Janeiro: Martins Fontes, 1988. Reflexões sobre o ano de 1909. P.144.

${ }^{13}$ Idem, ibidem.
} 
de objetividade racional e universalidade do sujeito, o movimento romântico provocou uma grande ruptura no pensamento europeu das últimas décadas do Setecentos, fundindo várias fontes filosóficas, estéticas e religiosas em uma confluência de vertentes autônomas com diferentes tradições nacionais. A uniformidade racional do pensamento iluminista, que ordenava as ideias de Razão e Natureza numa mesma matriz filosófica desde o século XVII, desempenhou função restritiva na relação entre o ser e o mundo. O racionalismo cartesiano compartilhado por todos e a ideia de leis naturais iguais em qualquer lugar reconheceu o homem como sujeito universal de conhecimento e de diretos inatos. O nivelamento das particularidades culturais de nações e povos era veiculado por verdades essenciais mais próximas ao causalismo mecanicista, e mais afastadas da metafísica. Essa limitação da singularidade do indivíduo exprimiu-se, em termos estéticos, na retomada pelos paradigmas clássicos. $O$ neoclassicismo se estabeleceu como proposta de uma "normatividade do bom gosto"14, onde a arte pairava nos limites da natureza.

No campo estético, a reação contra os padrões classicistas encontrava nos preceitos de interioridade e subjetividade a concretização de um comportamento espiritual definido em uma visão de mundo particular. O pathos romântico atravessaria, assim, o pós-impressionismo, o Expressionismo e o Surrealismo, perseverando até os movimentos americanos de neovanguarda, ou mais além. A arte assumia, pela primeira vez, valores de relevante independência e liberdade do espírito. Sendo um produto da cultura norte-europeia, o Romantismo encontraria na Alemanha a sua "morada privilegiada"15, exercendo influência, direta ou indiretamente, em todas as correntes românticas ocidentais. As origens teóricas do movimento foram sustentadas por uma combinação de princípios das doutrinas pós-kantianas de Fitche, com a transcendência do sujeito e sublimidade do Eu, e de Schelling, propondo a ideia de Natureza como individualidade orgânica.

No final do século XIX, a reação contra a influência do Impressionismo francês na Alemanha e o contato com o trabalho dos artistas pós-impressionistas levavam à tensão que deflagraria o movimento expressionista. $\mathrm{O}$ meio intelectual

\footnotetext{
${ }^{14}$ NUNES, Benedito. A visão romântica. In: GUINSBURG, J (org.). O Romantismo. P.56.

${ }^{15}$ BORNHEIM, Gerd. A filosofia do Romantismo. In: GUINSBURG, J (org.). O Romantismo. P.77.
} 
alemão vivia um momento conturbado pela herança do difícil processo político a partir da fundação do Império, que assegurou unificação geopolítica sem coesão no campo cultural. As artes visuais sofriam com a inércia do conservadorismo e do naturalismo acadêmicos, contudo o Expressionismo não nasce polemizando contra o passado, suas relações com o Impressionismo foram explícitas. O que não havia era a característica de tradição no movimento, os artistas escolhiam pontos de referência em alguns mestres do passado, mas com o intuito de ultrapassá-los.

A tendência anti-impressionista, que tanto inspirou as correntes norteeuropéias, manifestada por artistas como Henri de Toulouse-Lautrec, Paul Cézanne, Ferdinand Hodler, Paul Gauguin, Vincent Van Gogh, Edvard Munch, James Ensor, os fauves, entre outros, partia de dentro do próprio movimento como consciência e superação de seu caráter essencialmente sensorial, apresentando gradações mais rígidas nos países do Norte europeu. Apesar do movimento expressionista ser a antítese ao Impressionismo, ele o pressupunha: ambos exigiam a dedicação total do artista à questão da realidade, mesmo que o primeiro a resolvesse no plano do conhecimento e o segundo, no campo da ação. A investigação estética buscava o mundo interior da verdade pessoal, da expressão onde "o sujeito por si imprime o objeto" $"$, colocando o problema da relação concreta do homem com a sociedade e, portanto, da comunicação.

A ascendência transgressora de Ensor e Munch incidiu fortemente no caráter espiritual dos movimentos alemães. Considerado a face escura e sombria da pintura modernista, Ensor foi o primeiro a revelar as profundezas do inconsciente, a intensidade das imagens na clareza da forma, antes mesmo que as teorias psicanalíticas de Freud se difundissem. Subverteu a identidade entre arte e consciência dos impressionistas, chegando em algumas obras à destruição da figura e à subversão dos signos quanto à obrigação de significar. A cor se liberta para assumir uma vitalidade própria, autônoma e agressiva. Munch teve influência ainda mais decisiva nas correntes expressionistas, trazendo consigo o sentimento trágico da vida, a queda inexorável do humanismo iluminista na sociedade industrial moderna. Como Ensor, também não acreditou na superação completa do

\footnotetext{
${ }^{16}$ ARGAN, Giulio Carlo. Arte Moderna. P.227.
} 
Impressionismo, mas na sua inversão como deslocamento da realidade externa para a interna. A tendência espiritualista de Munch passou pelo simbolismo mas sofreu um tipo de inversão, segundo Argan: deixou de ser um processo de transcendência para radicar-se na imanência ${ }^{17}$. O símbolo está dentro da realidade, nas raízes do ser, da existência e do amor. A cor não tem mais o papel de retratar e, sim, de expressar. Nas gravuras, a cor estava conectada à sensação e emoção visual, aplicada a posteriori já que não pretendia definir nada além da atmosfera da imagem. A inspiração de Munch, como a de Ensor, não ultrapassaria em muito a primeira década do século $\mathrm{XX}$, quando ambos se tornaram pintores oficiais das classes dirigentes de seus países. O crítico de arte David Sylvester chama a atenção para a originalidade da geração de artistas do período pré-Primeira Grande Guerra, cuja extrema inventividade fazia aflorar o que cada artista tinha de melhor: os mais velhos se superavam e os mais novos, com poucas exceções, alcançavam uma excelência tal que, posteriormente, não conseguiriam manter. "Nos anos que antecederam 1914, todo o mundo da arte possuía aquele tipo de energia criativa que comumente se diz ser prerrogativa de gênio que está prestes a sofrer uma morte prematura." 18

$\mathrm{Na}$ virada do século $\mathrm{XX}$, quando as artes visuais alemãs conviviam com parcos reflexos impressionistas que se misturavam às fantasias simbolistas da Secessão de Munique ${ }^{19}$, o grupo alemão Die Brücke surgia como parte deste profícuo período, um dos "supremos"20, da História da Arte. Kirchner, Heckel, Nolde, Schmidt-Rottluff, entre outros, os principais expoentes dessa corrente, propunham a união dos elementos revolucionários mais severamente contra as repercussões do impressionismo francês na Alemanha do que em oposição ao movimento propriamente dito. Cézanne, por ter sua importância reconhecida pela Brücke, era uma das exceções ao embate. Para este grupo, a arte devia prescindir de tudo o que preexiste à ação do artista, era preciso começar a partir do nada. A

\footnotetext{
${ }^{17}$ ARGAN, Giulio Carlo. Arte Moderna. P.215.

${ }^{18}$ SYLVESTER, David. Sobre Arte Moderna. P.88.

${ }^{19}$ Nos países da Europa central, os artistas modernistas formaram grupos que assumiram o nome de Secessão, em alusão à separação radical da tradição acadêmica. Em 1892, funda-se a Secessão de Munique, tendo à frente Franz von Stuck; em 1893, a Secessão de Berlim, liderada por Max Liebermann; em 1897, a Secessão de Viena, que publica a revista Ver Sacrum e tem como líder Gustav Klimt.

${ }^{20}$ SYLVESTER, David. Loc.cit.
} 
experiência de mundo do artista não tinha distinção em relação a vivência comum, o que justifica os temas quase sempre ligados à crônica da vida cotidiana.

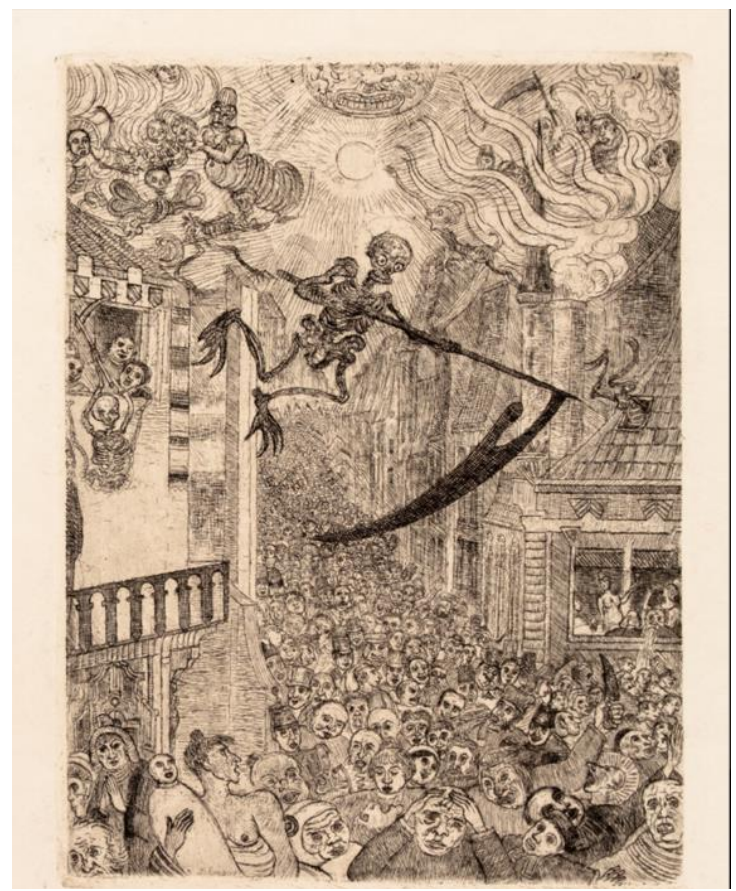

Figura 1: ENSOR, JAMES. Morte perseguindo o rebanho dos mortais, 1896. Gravura à água-forte e água-tinta, 23,4 x 17,5 cm.

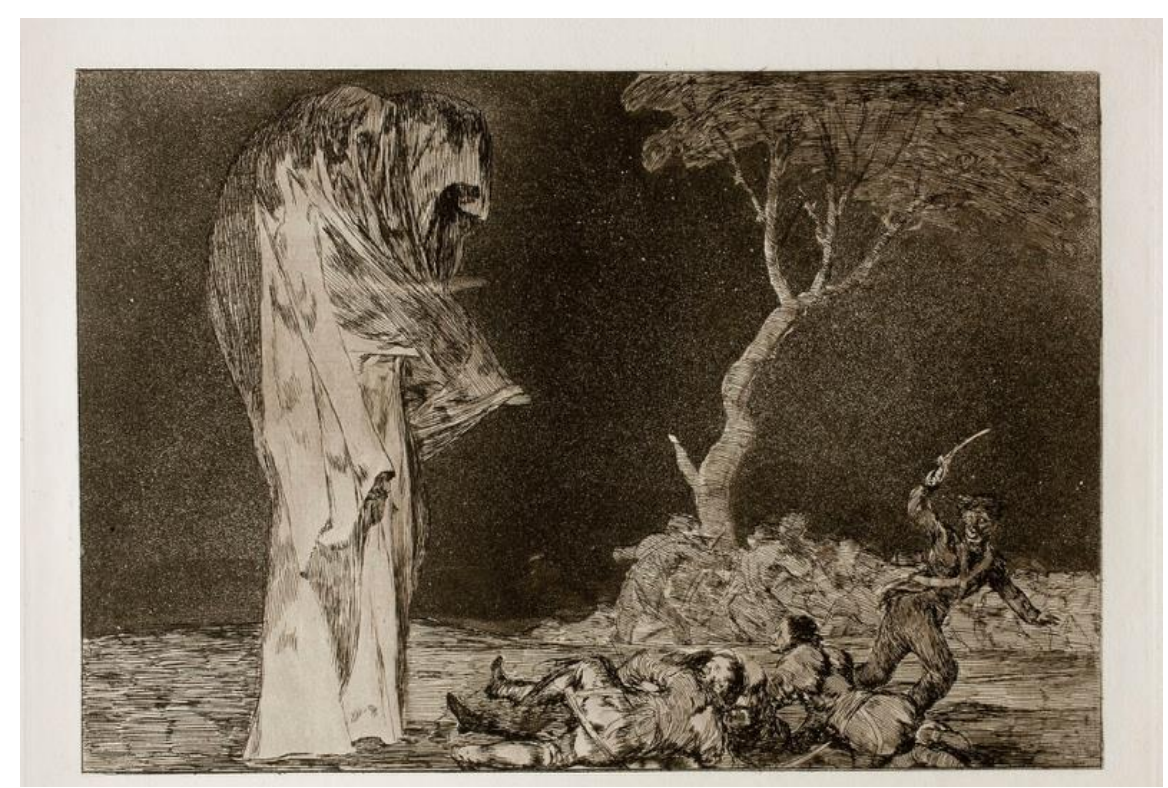

Figura 2: GOYA, FRANCISCO. Disparate do medo, 1824.

Gravura à água-forte e água-tinta, 24,7 x 34,7 cm. 


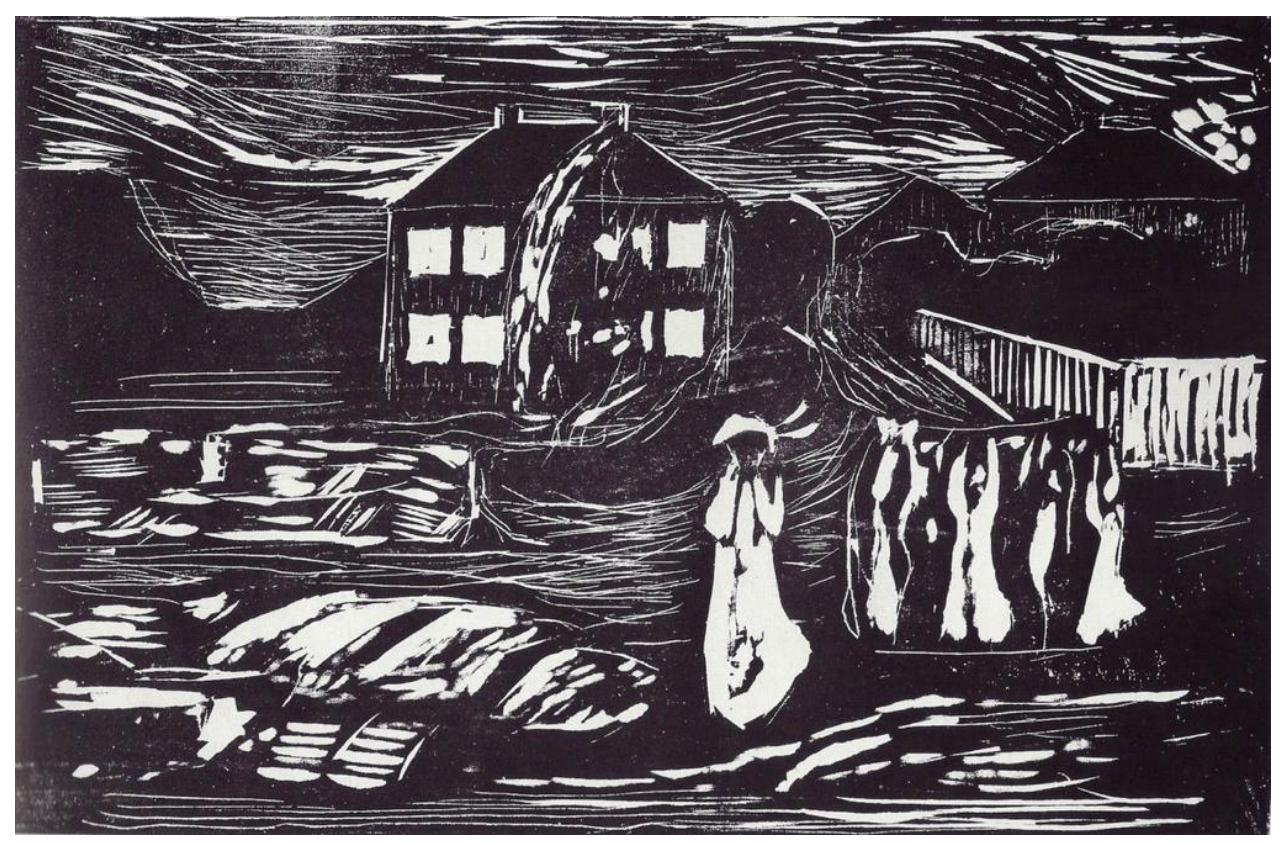

Figura 3: MUNCH, EDVARD. A tempestade, 1908-1909. Xilogravura, 23,6 x 16,9 cm.

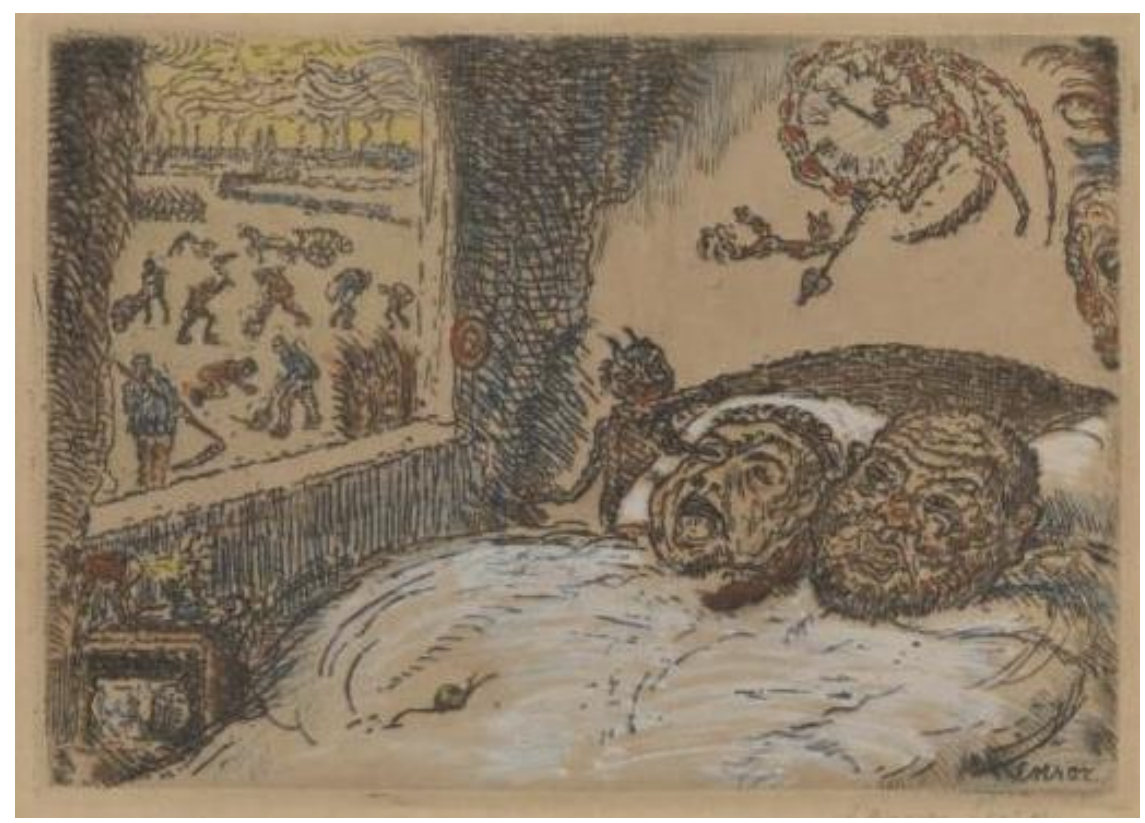

Figura 4: ENSOR, JAMES. Preguiça, 1902.

Gravura à água-forte e água-tinta, 13,6 x 9,6 cm. 
A técnica era o meio de representação da imagem tanto para os impressionistas quanto para os clássicos. Para a Die Brücke, como a imagem não preexistia à ação, prevalecia o modo de fazer. A técnica era o trabalho em si e se distinguia do ofício mecânico industrial e da racionalidade e lógica da cultura intelectual. Os artistas bruckeanos adotaram a arte dos "primitivos" como referência, não procurando, contudo, os símbolos de mitos distantes: procuravam, isto sim, a produção humana em estado puro, em sua plena criatividade. A vontade exteriorizada no prazer do ato de fazer atraía as atenções do grupo como bem definiu Nolde: "A absoluta espontaneidade, a extrema intensidade, frequentemente grotesca, da energia e da vida em suas mais variadas formas talvez seja isso que nela (arte primitiva) nos agrade." 21

Conclui-se daí a importância dada às artes gráficas pela Brücke, especialmente à xilogravura. Arcaica, artesanal, popular e profundamente arraigada à tradição ilustrativa alemã, a técnica da gravura era uma maneira habitual e profícua de expressão e comunicação imagética, na qual o ato de expressar não era um mistério entre o artista e o mundo: a comunicação passava de um homem a outro, como uma ponte (Brücke). Na impressão xilográfica, a imagem conserva as marcas das operações manuais, dos atos de violência sobre a matéria e das marcas visíveis das fibras da madeira. A imagem não se liberta da matéria, ambas se confundem num ato de força.

$\mathrm{Na}$ medida em que a obra materializava diretamente a imagem, é desnecessário que o artista escolha as cores segundo o critério de verossimilhança. Era um processo de atribuição de significado através da cor. $\mathrm{O}$ atributo implicava em um juízo, uma postura moral ou afetiva em relação ao objeto, que se manifestava como deformação ou distorção do próprio objeto. Essa deformação expressionista não era ótica ou caricata, era determinada por fatores subjetivos na intencionalidade com que se aborda a realidade presente - e objetivos - na identificação da imagem com a matéria resistente. Quando a beleza passou da dimensão do ideal para o campo do real, inverteu seu significado, tornando-se

\footnotetext{
${ }^{21}$ NOLDE, Emil. Emil Nolde, anos de luta. In: Chipp, H.B. As teorias da arte moderna. P.144.
} 
fealdade..$^{22}$ Assim, trazia a marca da dubiedade poética expressionista por ser ambígua a própria condição existencial do homem.

Em oposição ao Cubismo, reconhecendo sua ação renovadora mas contestando seu fundamento racionalista, o movimento Der Blaue Reiter (O cavaleiro azul) foi fundado por Kandinsky, em 1911, e tem o gravurista e desenhista Alfred Kubin como um dos seus integrantes, além de Paul Klee e outros. Um grupo mais restrito que a Brücke, sem um programa muito definido, mas com uma forte orientação espiritualista. Através de exposições internacionais e textos teóricos polêmicos, a finalidade era coordenar e defender as tendências pelas quais o campo da arte se distingue do campo da natureza e reafirmar a determinação das formas artísticas dependentes exclusivamente dos impulsos interiores do objeto. A comunicação estética, pelo contrário, era intersubjetiva, de homem a homem, sem a intermediação do objeto. O primitivismo era incorporado de forma radical, remetido ao estágio inicial de pura intencionalidade ou vontade expressiva, sem apoio de nenhuma experiência linguística.

Independentemente de serem considerados pertencentes ao movimento expressionista alemão, tanto o grupo Der Blaue Reuter quanto a corrente Die Brücke tinham concepções estéticas e práticas bem diferentes. Como explica Claudia Valadão de Mattos, o movimento de Munique visava uma autonomia da atividade artística em relação às demais esferas da vida, o grupo de Dresden tinha sua práxis voltada para reintegração entre arte e vida. Os membros da Brücke acreditavam que para concretizarem suas ideias dependiam de uma transformação radical da própria vida do grupo:

\footnotetext{
"Alugaram um espaço na Berlinerstrasse, em Friedrichstadt, um bairro proletário de Dresden, que passou a servir como ateliê coletivo, e acima de tudo, como local para uma experiência comunitária. Nesse ambiente os membros do grupo conviviam cotidianamente. O local foi decorado com móveis de fabricação própria e as paredes foram cobertas com cores brilhantes e pintadas com imagens inspiradas na 'arte primitiva' de povos africanos e da Oceania". ${ }^{23}$
}

\footnotetext{
${ }^{22}$ ARGAN, Giulio Carlo. Arte Moderna. P.240.

${ }^{23}$ MATTOS, Claudia Valadão de. Expressionismo alemão, arte e vida. P. 21.
} 
Apesar do maior legado desses artistas ter sido o conjunto de pinturas e esculturas, e, por que não, gravuras e desenhos, a Brücke muito contribuiu para o alargamento das fronteiras da arte quando deu ênfase à $a c ̧ a \tilde{o}$ em seus primeiros anos. A pintura funcionava apenas como testemunho da experiência comunitária, o ato era despido de convenções e orientado pela vontade, fazendo do processo da arte sua poética, atitude que reverberaria de Goeldi a Jackson Pollock, considerando as devidas diferenças.

Mesmo fazendo parte do Der Blaue Reiter, que não estampava a mesma coerência estética que a Die Brücke, Kubin privilegiou a transcendência da imaginação, aproximando-se mais de artistas como Gustave Moreau, Odilon Redon e Arnold Böcklin. Partindo das linguagens representativas não-racionais do movimento, mergulhou profundamente num simbolismo sombrio que permeou toda a sua obra. A arte de Kubin não tinha intenção de representar, revelava por signos uma realidade além da consciência. As imagens se erguiam das profundezas do ser e se encontravam com as que provinham do exterior, como uma continuidade entre mundo objetivo e subjetivo. Em sua gráfica ilustrativa, com claras ressonâncias de Ensor, desenvolveu uma escrita figurada da descrição angustiada das imagens monstruosas que ocuparam o espaço do mundo sob a máscara da vida cotidiana. O contato que teve com a obra do gravador e escultor Max Klinger, que também influenciou Munch e De Chirico, foi decisivo na associação do traço realista com a fantasia. Atmosfera de estranheza e ambiência de sonho faziam parte das cenas com que o austríaco se identificava, mesmo produzindo traços menos realistas e narrativos que Klinger:

"Desde cedo tive uma particular inclinação para o exagero e para o fantástico; uma vaca com quatro chifres sempre me foi mais cara que aquelas com apenas dois, e que então podiam ser encontradas em qualquer esquina de Zell am See."24

\footnotetext{
${ }^{24}$ KUBIN, Alfred. Apud NAVES, Rodrigo. Goeldi. P.13.
} 


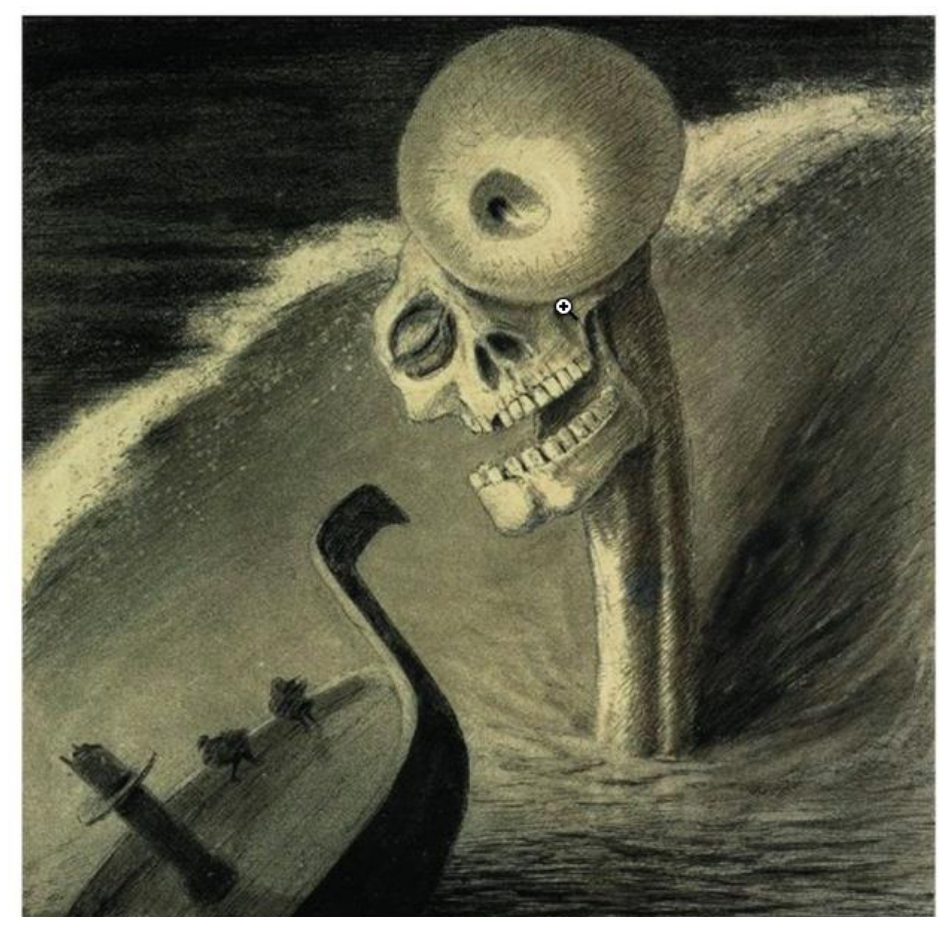

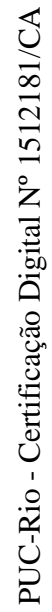

Figura 5: KUBIN, ALFRED. O horror, 1912. Nanquim sobre papel

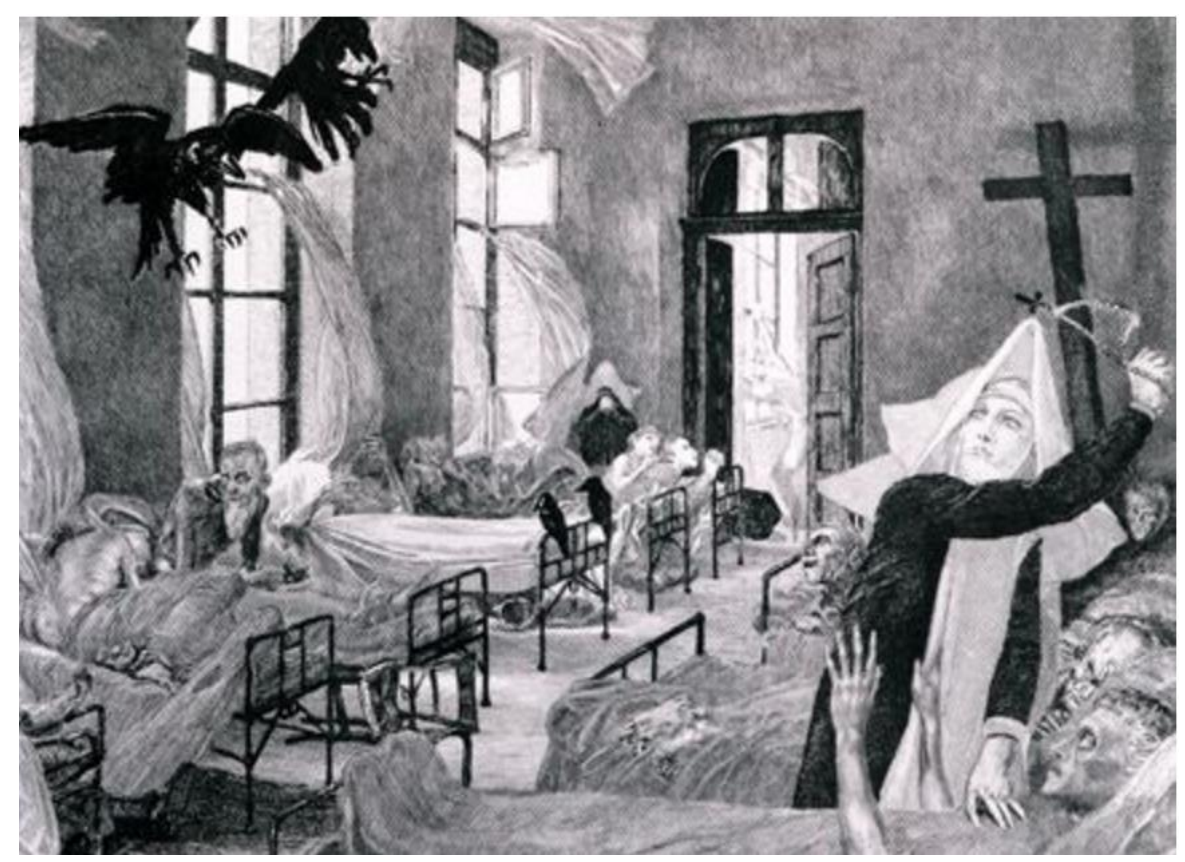

Figura 6: KLINGER, MAX. Praga, 1903.

Gravura à água-forte, 36,2 x 31,5 cm. 
Kubin, que participou do mesmo ambiente cultural que Freud, considerava que os elementos reprimidos pela psicologia humana, representados nos sonhos, denotavam a "dimensão traumática da existência". A degeneração da sociedade pós-Revolução Industrial era captada e revelada nos cenários fantasmagóricos, em que aspectos sinistros das figuras promoviam a perplexidade do expectador. As afinidades românticas o levaram a ilustrar importantes obras de E.T.A. Hoffmann, Edgar Allan Poe, Nikolai Gogol, Franz Kafka e Fiódor Dostoiévsky, onde personagens, por vezes desorientados e febris, revelam a realidade decepcionante do mundo moderno.

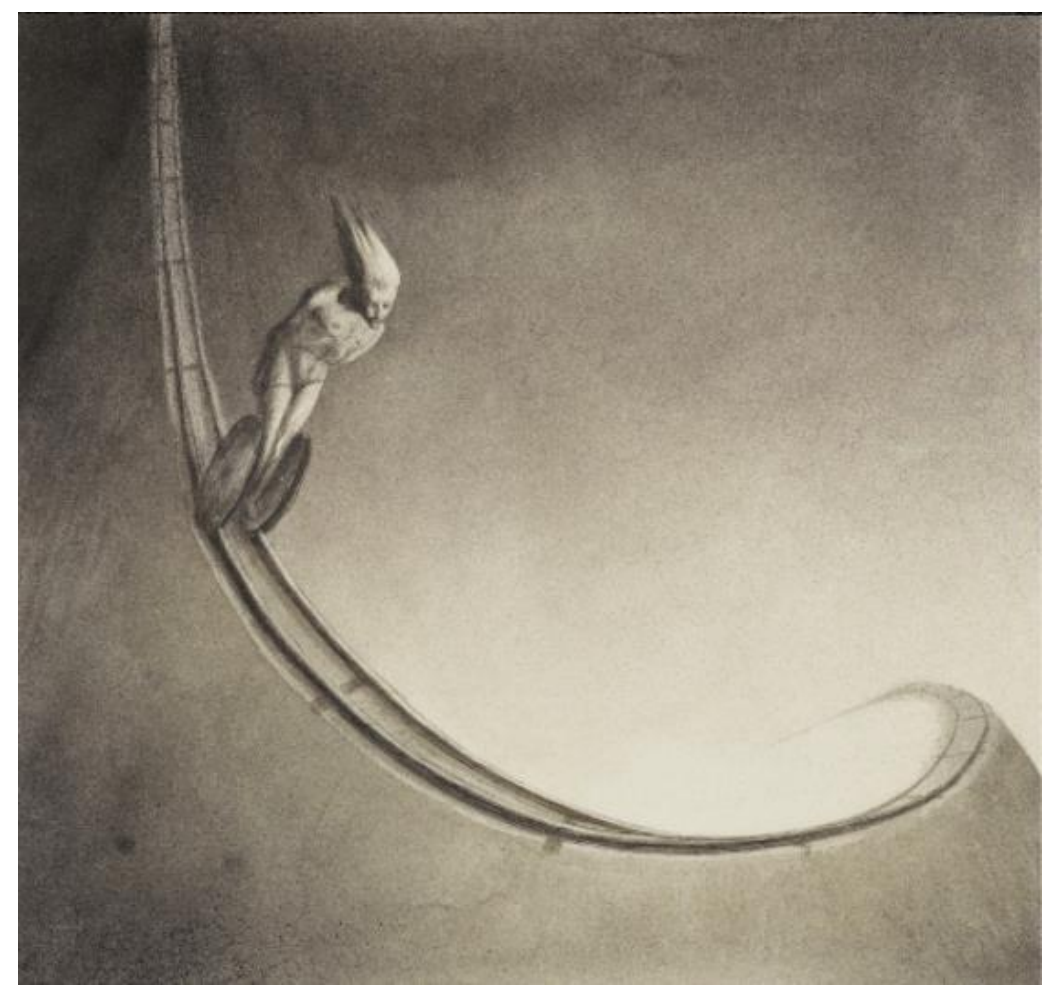

Figura 7: KUBIN, ALFRED. Homem, 1902. Nanquim sobre papel, $38,5 \times 31,4 \mathrm{~cm}$.

O simbolismo de Kubin também passa por Goya. Assim como Ensor e Munch, o artista espanhol se tornou pintor de prestígio em seu país, mas com uma importante particularidade ambígua: à luz da opinião pública seguia os cânones acadêmicos apoiado pelo conservadorismo das instituições oficiais, sendo o pintor preferido dos reis da Espanha, porém, na intimidade de seu ateliê, mergulhava na realidade do mundo e no simbolismo dos sonhos. Após um bem-sucedido período rococó, passou a compor uma pintura figurativa que aproxima a realidade da imaginação visionária. Como as calamidades humanas suscitavam sua 
curiosidade, produz séries de gravuras, como Caprichos e Disparates (Fig. 2), que investigavam a natureza do ser através de visões fantasmagóricas e legendas inquietantes. Os homens são representados por bestas, gnomos, fantasmas, aves, monges, cuja simbologia é inicialmente inspirada pelo vigor das ideias iluministas com que compactuava, principalmente as que redefiniam os papéis da Igreja e do Estado. Logo depois, suas gravuras refletirão a crueldade oculta no próprio sistema libertador do Iluminismo e nos exageros da Revolução Francesa e das guerras napoleônicas. ${ }^{25}$

Goeldi considerou Kubin seu grande mestre e fonte de inspiração, mas ainda que a admiração tenha permanecido até o fim, sua obra foi se distanciando progressivamente da influência simbolista do artista austríaco. As influências no trabalho do artista brasileiro passaram fortemente pela tensão de Van Gogh, cuja solaridade, a princípio díspare, se reflete nas estrias da sombria luz das gravuras e em desenhos goeldianos. Encontrou eco no primitivismo e na apropriação de elementos da natureza de Gauguin, Nolde e Heckel. Absorveu algo da atmosfera de melancolia e das experimentações de cor das gravuras de Munch; do descontentamento com o mundo por distorções do sonho e da fantasia de Goya, Kubin e Klinger; e da geometrização figurativa de Beckmann e Schmidt-Rottluff. Repercussões que aliadas à técnica artesanal da xilogravura, transformada em reprodução de rigor quase ritualístico, transcenderam a simples reprodução das gravuras:

"A litografia não dava o desenho tal como eu queria e assim desisti. Gravei uma época em metal. Mas voltei a gravar em madeira, a madeira correspondia mais a meu temperamento. E sempre fazendo xilografia a exemplo de Munch e dos experimentos dos alemães Beckmann, Schmidt-Rottluff etc."26

A ascendência de Kubin é percebida fortemente nos desenhos a nanquim e nas litografias do início de sua produção. Apesar de um certo simbolismo permear toda a sua obra, Goeldi se afastará completamente da estranha poética visionária kubiniana. O caminho expressivo encontrou na técnica da xilogravura a ligação estruturante com o primitivismo de base das correntes pós-impressionistas e expressionistas norte-europeias. Ao mesmo tempo que recusou a produção

\footnotetext{
${ }^{25}$ TODOROV, Tzvetan. Goya, à sombra das luzes. P.93.

${ }^{26}$ Entrevista de Oswaldo Goeldi a Ferreira Gullar. Suplemento Dominical do Jornal do Brasil, em 12/01/1957. In: BRITO, Ronaldo. Oswaldo Goeldi. Coordenação de Silvia Roesler. Pg. 210.
} 
mecânica industrial, assumiu a produção em série, rejeitando a ideia de obra única, investindo na forma de comunicação brückeana entre um homem e outro. A essência romântica que formou sua personalidade se manteve inalterada, mas, apesar de tudo, a definição da poética singular e temática original somente se forjaram na problemática ambiência brasileira de miséria, abandono e instabilidade, a partir do olhar do artista sempre exilado - europeu no Brasil e brasileiro na Europa - considerado à margem das particularidades culturais e sociais de cada lugar. Otto Maria Carpeaux resumiu o encontro de Goeldi com suas inspirações expressionistas como um fortalecimento da "convicção de ter enveredado pelo caminho certo: seu próprio caminho". ${ }^{27}$

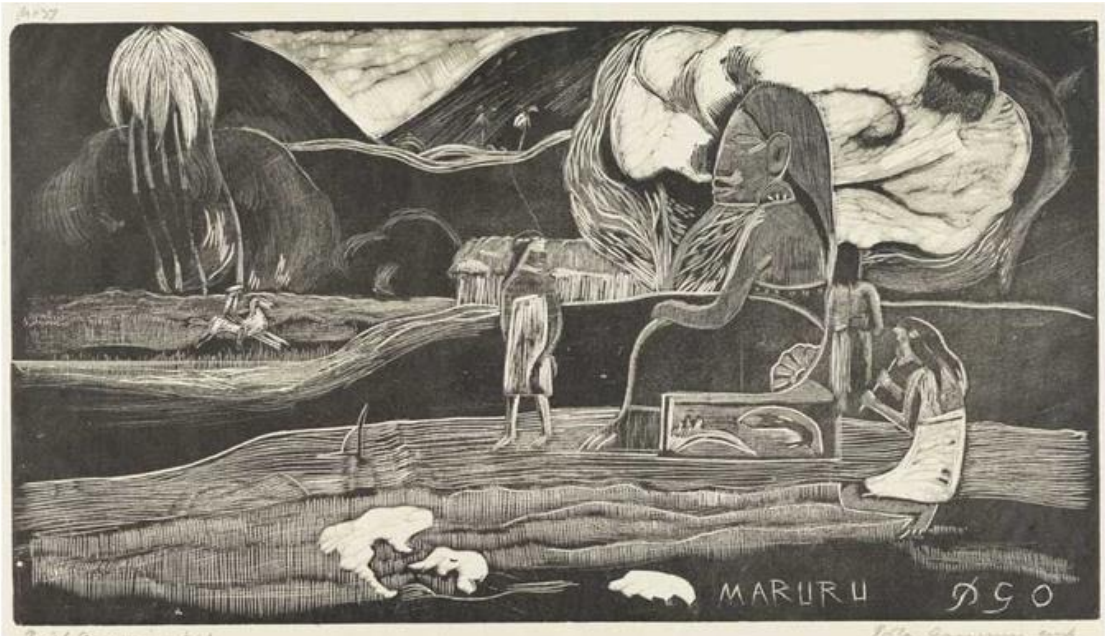

Figura 8: GAUGUIN, PAUL. Maruru de Noa,Noa, 1893-1894. Xilogravura, $20,5 \times 35,5 \mathrm{~cm}$.

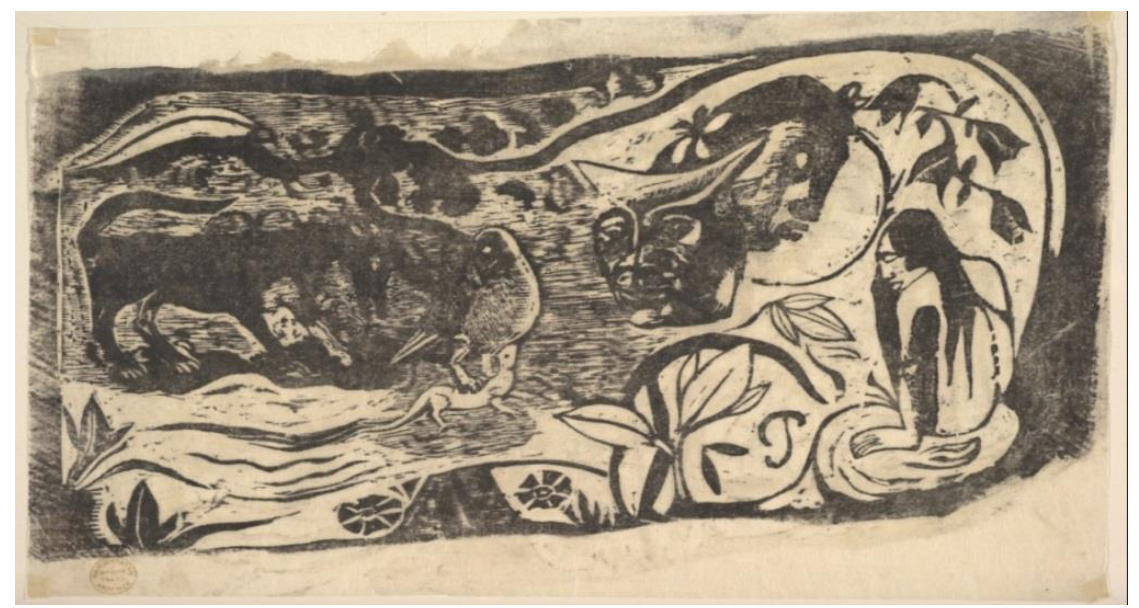

Figura 9: GAUGUIN, PAUL. Cabeça de chifre, 1893-1894.

Xilogravura, $14,28 \times 28,57 \mathrm{~cm}$

\footnotetext{
${ }^{27}$ CARPEAUX, Otto Maria. Goeldi e Kubin In: RIBEIRO, Noemi, coordenação. Oswaldo Goeldi na coleção Hermann Kümmerly. P.19.
} 


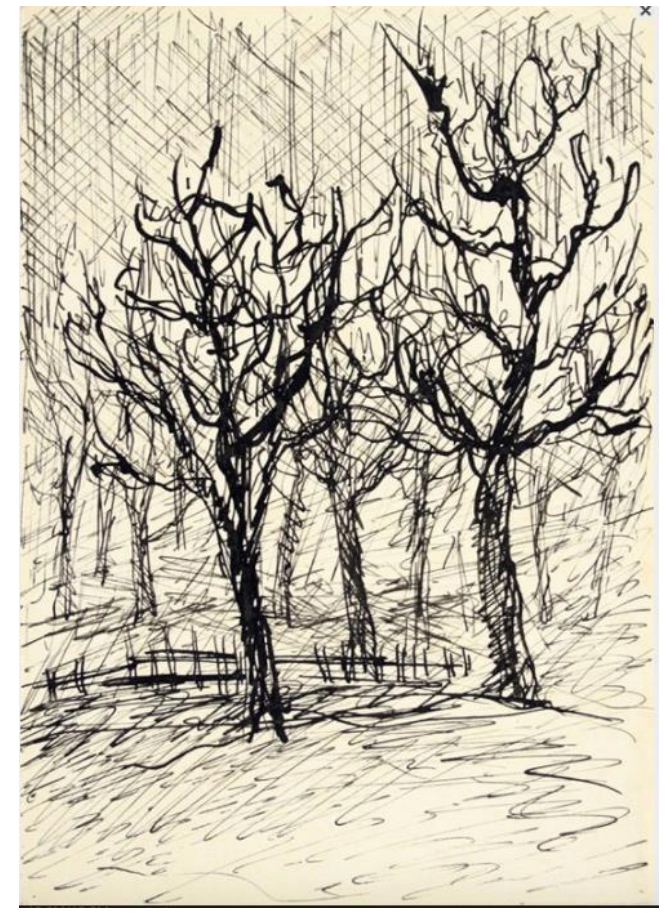

Figura 10: GOELDI, OSWALDO. Sem título, s/d. Bico de pena sobre cartão.

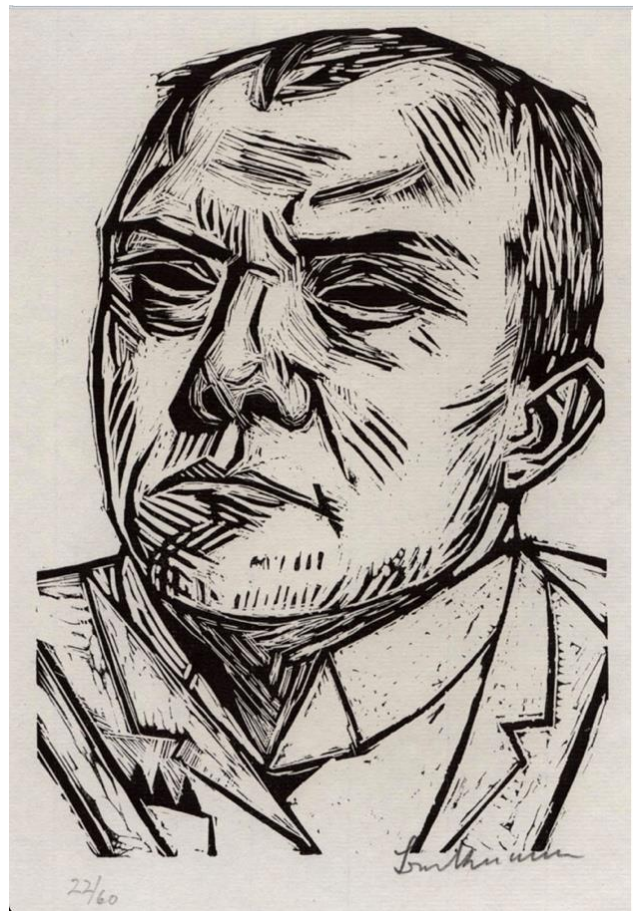

Figura 11: BECKMANN, MAX. Autorretrato, 1922.

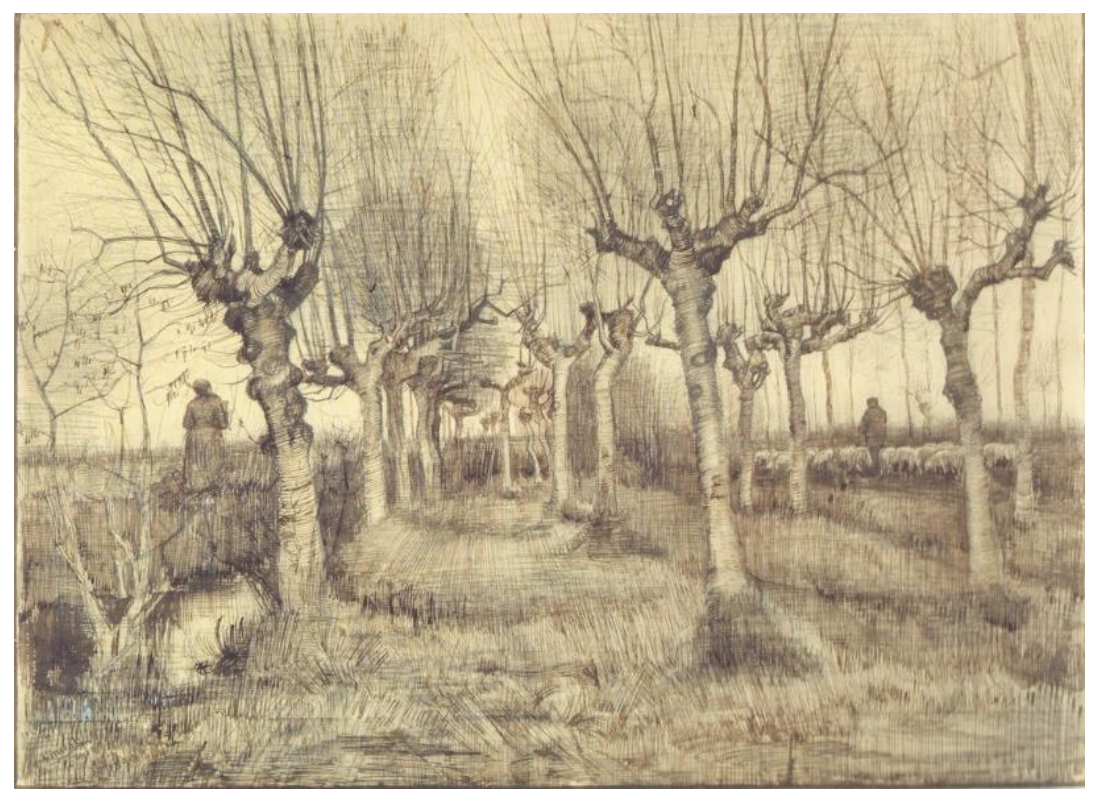

Figura 12: VAN GOGH, VINCENT. Bétulas podadas, 1884. Nanquim e aquarela sobre papel, $39,5 \times 54,2 \mathrm{~cm}$. 


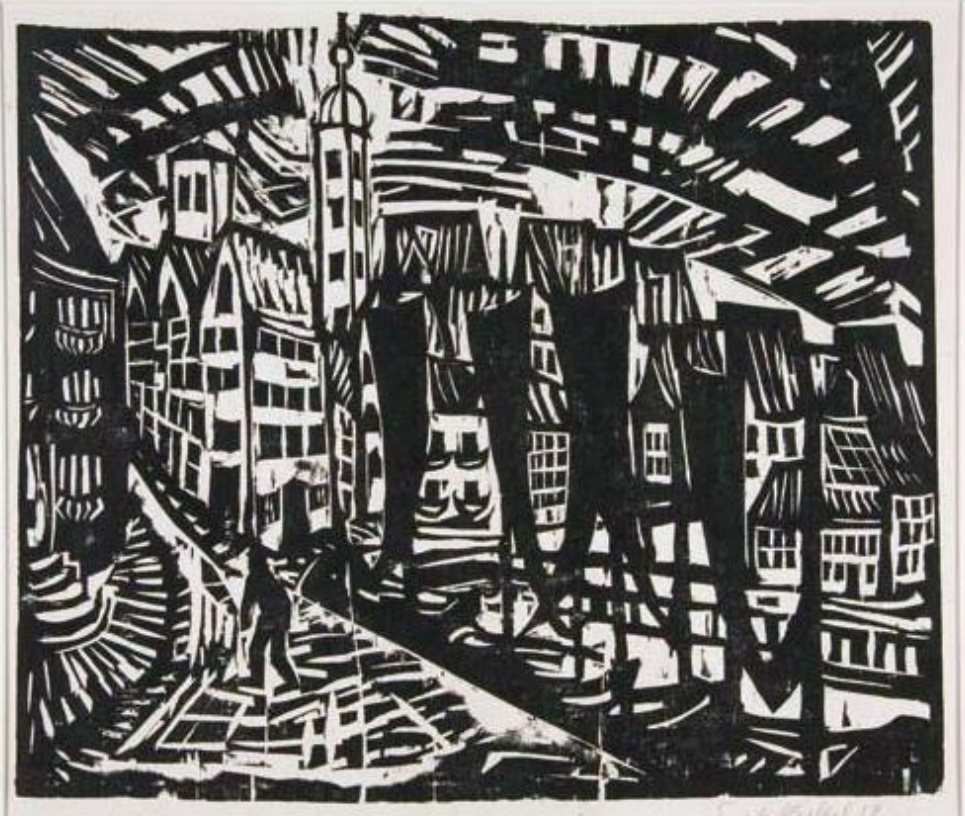

Figura 13: HECKEL, ERICH. Stalsund, 1912. Xilogravura, $31 \times 36,5 \mathrm{~cm}$.

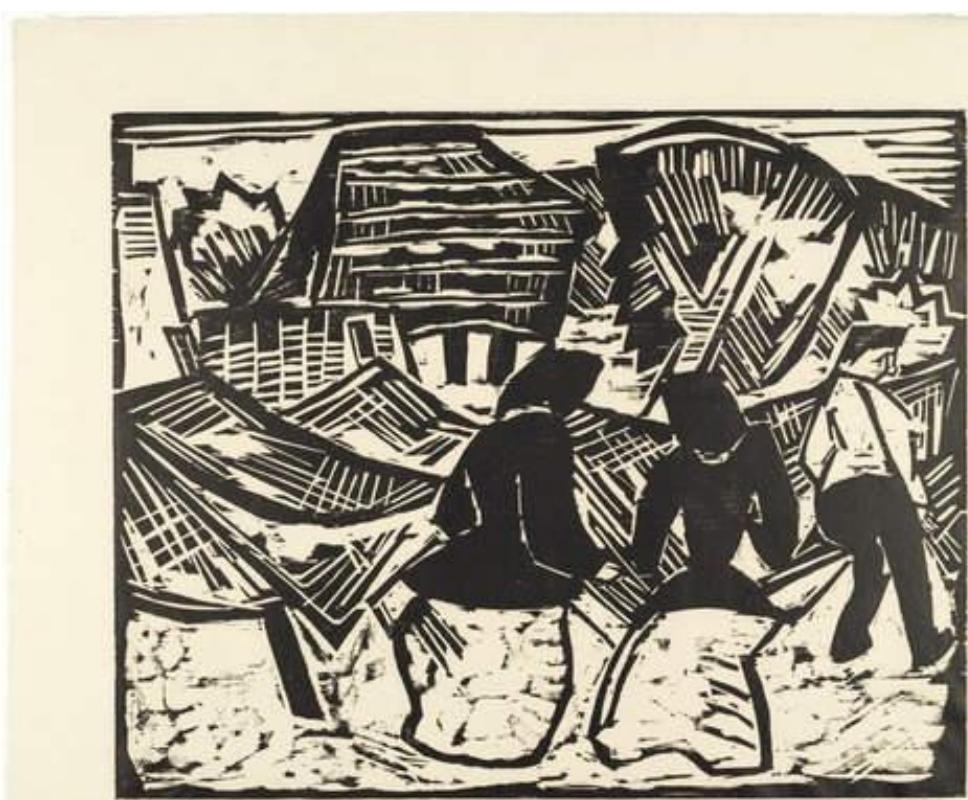

Figura 14: ROTTLUFF, KARL-SCHMIDT. Nas redes, 1914. Xilogravura, 40 X 49,5 cm. 


\title{
2.2
}

\section{A xilogravura: matéria e técnica expressivas}

\author{
"Quanto mais a matéria é, em aparência, positiva e sólida, \\ mais sutil e laborioso é o trabalho \\ da imaginação" 28 \\ Charles Baudelaire
}

Dilemas técnicos foram assíduos no caminho criativo de Goeldi. Após produzir o primeiro álbum ${ }^{29}$, o impasse angustiante na relação com a matéria era evidente: "Estou cansado da madeira. Ela limitou rapidamente os meus horizontes - improvisar com grafite na madeira é maravilhoso, mas o material é duro, frio e odioso" 30 . Reconhecia que para um trabalho "com garra, apaixonado, ela (a xilogravura) é única" ${ }^{\$ 1}$, mesmo assim, se preocupava com a tendência à repetição das formas, o que seria inevitável a curto prazo. Entretanto, foi no percurso da gravura, fraturado e dramático, que encontrou a autenticidade de uma obra plástica singular e moderna de contornos existenciais.

No árduo trajeto para alcançar a expressão peculiar, ambígua e intransigente de suas gravuras, Goeldi optou por uma construção poética com técnica análoga à utilizada pelo modernismo da Europa do Norte, pouco conhecida no Brasil dos anos 1920 e 1930. Não sendo um artista precoce, a habilidade com o desenho se manifestou depois dos 20 anos quando ainda vivia na Europa. Experimentou à época a litografia e técnicas de aquarela, guache e nanquim. A xilogravura veio conhecer no Brasil, no ateliê do artista Ricardo Bampi, em 1924, que havia estudado na Alemanha de onde regressara após a guerra. A gravação começou como um "exercício", uma maneira de conter os devaneios a que o desenho o levava. Os primeiros trabalhos foram feitos em pequenos pedaços de madeira de corte irregular. A série intitulada 10 Köpfe ou 10 Cabeças, exibe os traços finos e nervosos característicos desta fase inicial, quando

\footnotetext{
${ }^{28}$ BAUDELAIRE, Charles. Curiosités Esthétiques, P. 317.

${ }^{29} 10$ Gravuras em madeira de Oswaldo Goeldi, 1930.

${ }^{30}$ Carta de Goeldi a Kubin, 01/02/1931. In: RIBEIRO, Noemi. Oswaldo Goeldi: um autorretrato. P.167.

${ }^{31}$ Idem, ibidem.
} 
utilizava goivas ${ }^{32}$ bem afiadas, acompanhando os veios dos tacos "aproveitados ao acaso"33. O álbum 10 Gravuras em Madeira, de 1930, prefaciado por Manuel Bandeira, impresso com tiragem de apenas 200 exemplares, já revelava muito do gravurista que encontramos nas décadas de 1940 e 1950. Com os anos, entretanto, por uma economia de meios, optou por representações imagéticas menos descritivas e riscos mais firmes e precisos. Incorporou a cor e manteve a intensidade da temática social, registrando pessoas e paisagens saídas de cenas aflitivas da vida urbana.

O processo artesanal da xilogravura se inicia na escolha da peça de madeira e sua preparação - aparelhamento e acabamento. A partir do desenho a grafite ou nanquim, diretamente sobre a placa, é feita a goivagem ${ }^{34}$. A aplicação da tinta é executada nas zonas de cor com pincéis ou rolos de pintura e o papel, sobreposto à matriz, é pressionado e impresso com a ajuda de uma colher de pau ou "espátula de osso" 35 , ou ainda com uma prensa mecânica. Goeldi elegia o modo artesanal de impressão operando com as próprias mãos e empregava efeitos utilizados por Munch, por membros da Die Brücke e até da escola de gravura japonesa Ukiyo$\mathrm{e}^{36}$. Pela idealização, o homem se dá a ilusão de excitar as potências formadoras de todas as matérias e as imagens que ele cria são eminentemente ativas. Estas abstrações sustentavam o artista quando passava a confiar na energia das próprias mãos. A preferência pelas fibras delicadas do papel japonês permitia a reprodução fidedigna do desenho, ao mesmo tempo que a fragilidade do material exigia bastante cautela. O que havia surgido apenas como alternativa técnica, estabelecia-se como opção concreta e definitiva.

A relação entre homem, ferramenta e matéria no processo técnico da xilogravura pode ser vista como rivalidade imediata em luta ardilosa. A necessidade de agir contra o objeto resistente era deflagrada, contudo, a administração das forças requeria singular prudência, lenta integração dos atos e delicadeza enquanto a peça era trabalhada. Havia um duelo entre duas vontades: a

\footnotetext{
${ }^{32}$ Goiva é o nome dado a uma série de instrumentos cortantes utilizados para o entalhe em madeira. A lâmina é curta, semelhante ao formão porém em menor escala, com diferentes formatos como lâmina reta, arredondada, em "U" ou "V".

${ }^{33}$ RIBEIRO, Noemi. Oswaldo Goeldi: mestre visionário. P.8.

${ }^{34}$ Processo de entalhe que utiliza a goiva. Ver nota de rodapé n.32.

${ }^{35}$ Ferramenta utilizada para alisar ou vincar o papel.

${ }^{36}$ RIBEIRO, Noemi. Op.Cit. P.9.
} 
do artesão em querer ajustar a madeira ao geometrismo do desenho e a vontade do material em querer conservar a sua forma e integridade. Como o elemento recusa a simetria, o artista precisava dosar delicados golpes com retenção de suas forças para, enfim, conquistar a simplicidade e resignação do objeto.

A escolha correta da matriz resultava, portanto, em condição essencial para o êxito da impressão. A riqueza de variedades, texturas e densidades das madeiras brasileiras foram aproveitadas em plenitude por Goeldi. Peroba-rosa, peroba do campo, mogno, pequiá-marfim e cedro foram algumas das espécies contempladas. Empreendia o que se chama, no jargão técnico da xilogravura, a madeira de fio, a partir do corte vertical da madeira em tábuas, na direção longitudinal da copa à raiz, no sentido do crescimento da árvore, deixando aparentes os veios da madeira. Diferentemente do corte de topo, transverso, onde se revelam os nós da peça, método também utilizado por Munch e pelos expressionistas germânicos. Seguindo a opção da xilogravura expressionista moderna, os finos veios originais eram aproveitados e se integravam aos sulcos rasgados dos desenhos, dando múltiplas direções aos filetes de luz que cortavam a massa escura e densa. Os vestígios de usos anteriores das peças, como sinais de pregos, arranhões e furos, que podem ser vistos em algumas matrizes, também eram incorporados por Goeldi às imagens. Na matriz de Paisagem noturna $(\text { Fig.16) })^{37}$, a depressão em forma oval, provavelmente oriunda de um nó da madeira, passou a fazer parte da cena como um redemoinho que dá o ritmo de tensão e movimento ao desenho (Fig.17). Em Vista urbana (Fig.15), o sulco vertical foi agregado ao desenho em sua totalidade como uma lateral do casario e do muro. O risco marca profundamente uma das linhas verticais, tão características do jogo geométrico dos casarios goeldianos. As rachaduras na placa de Luz sobre a praça (Fig.18) tornam-se quase imperceptíveis na imagem impressa, confundindo-se suavemente com os próprios veios da madeira (Fig.19). Ao levar em consideração as imperfeições da peça, a impregnação histórica da madeira era também integrada à superfície do desenho.

\footnotetext{
${ }^{37}$ A matriz está catalogada no MNBA com o título Paisagem noturna, enquanto sua impressão consta como sem título tanto em catálogos, como na publicação do jornal $A$ Manhã, de 17/06/1951. É frequente a imprecisão catalográfica quanto às obras de Goeldi. Xilogravuras e matrizes, que não foram nomeadas e datadas pelo artista, estão inventariadas com títulos diversos por diferentes fontes, o que gera inexatidão quanto à referência das obras. Por essa razão, neste trabalho, optamos por incluir todas as imagens citadas no texto.
} 


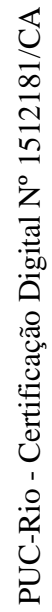
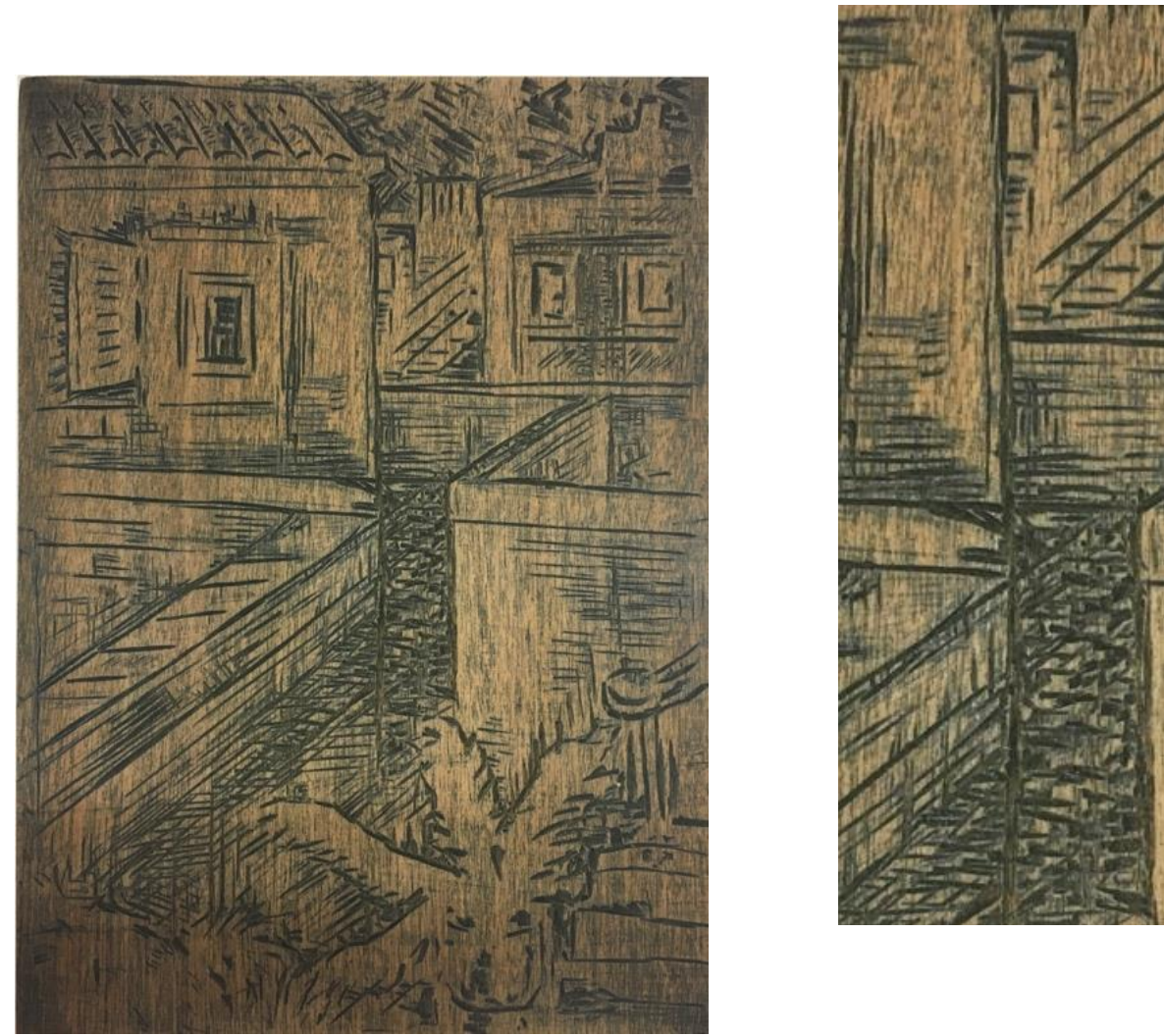

Figura 15: GOELDI, OSWALDO. Vista urbana, 1930.

Matriz xilográfica, MNBA.

Foto com detalhe do sulco preexistente na madeira
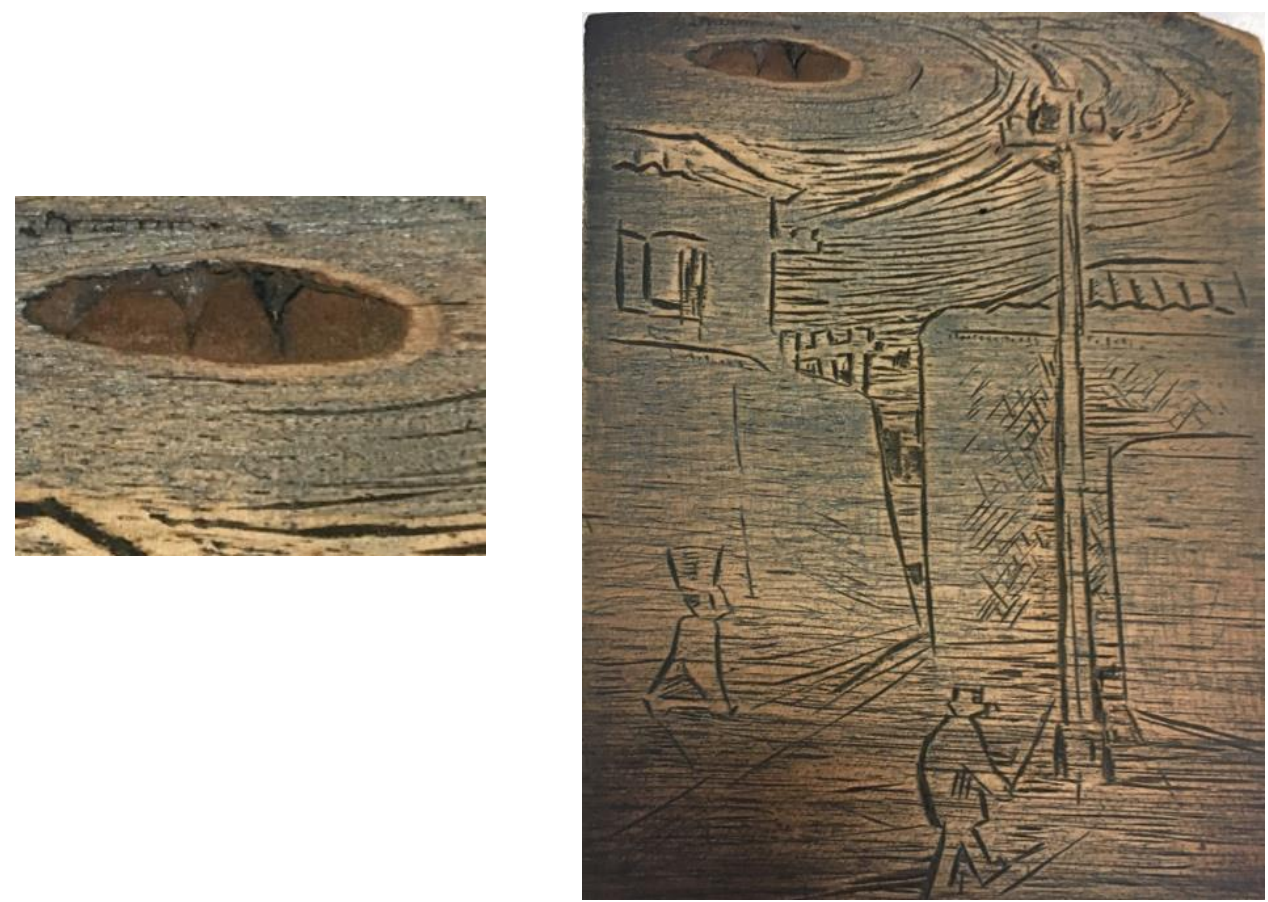

Figura 16: GOELDI, OSWALDO. Paisagem noturna, 1930.

Matriz xilográfica, 8,7 x 9 × 1,3 cm, acervo do MNBA..

Detalhe do nó da madeira. 


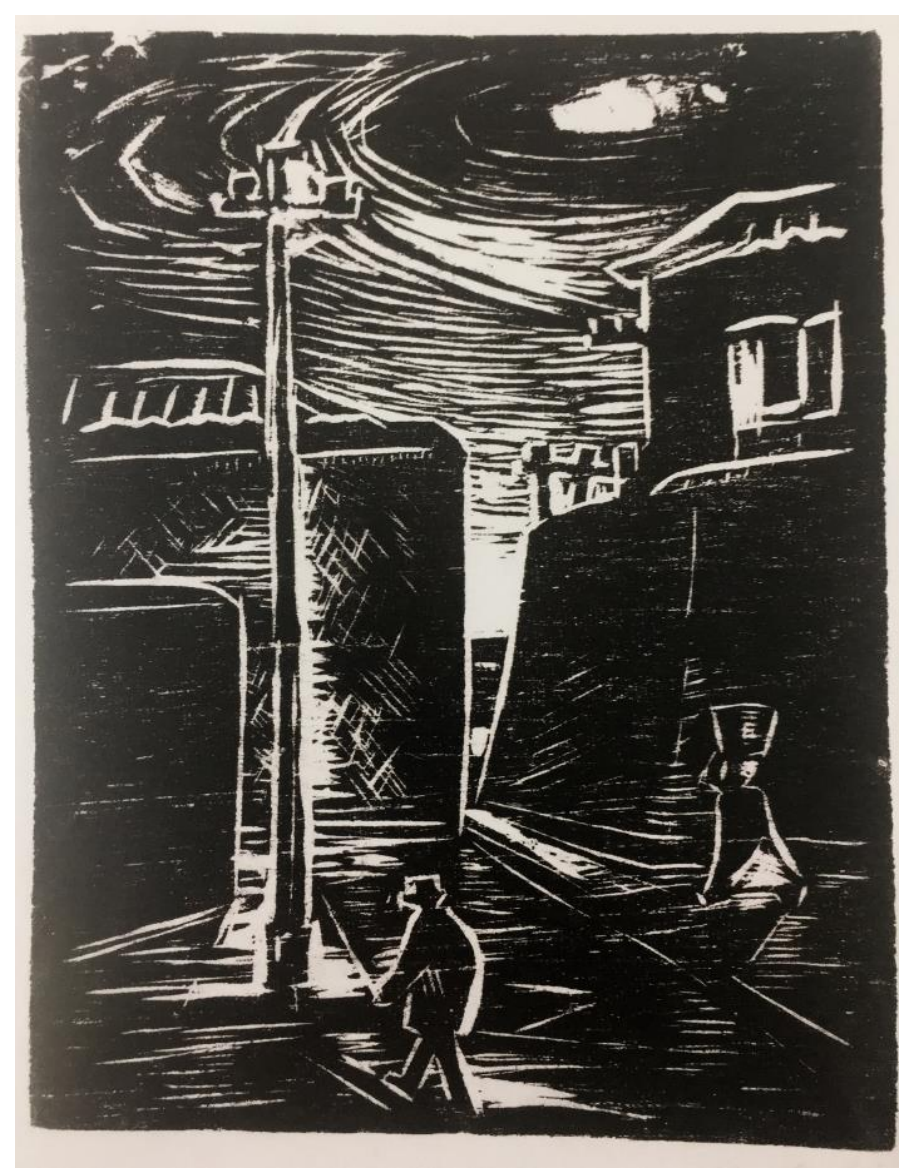

Figura 17: GOELDI, OSWALDO. Sem título (Paisagem noturna), 1951. Xilogravura, $15,2 \times 13,5 \mathrm{~cm}$.

A dureza da madeira funcionava como um tipo de provocação retribuída com o uso preciso da ferramenta. Ao admitir a hipótese que a imaginação da resistência atribuída às coisas está relacionada às violências que a vontade exerce contra estas mesmas, Bachelard afirma que é no trabalho exercitado de maneiras tão diferentes pelas matérias duras e macias que o sujeito toma consciência de suas próprias "potências dinâmicas" "38. A rigidez e a maciez levam a dinâmicas diferentes cujos materiais resistentes tornam-se "seres por dominar". Ao domar a madeira apropriando-se intensamente de seus recursos naturais, com pleno conhecimento do ofício da gravura, Goeldi cria um rico diálogo entre matéria e imaginação, dando um dos tons de sua singularidade poética.

\footnotetext{
${ }^{38}$ BACHELARD, Gaston. A terra e os devaneios da vontade: ensaio sobre a imaginação das forças. P.16.
} 

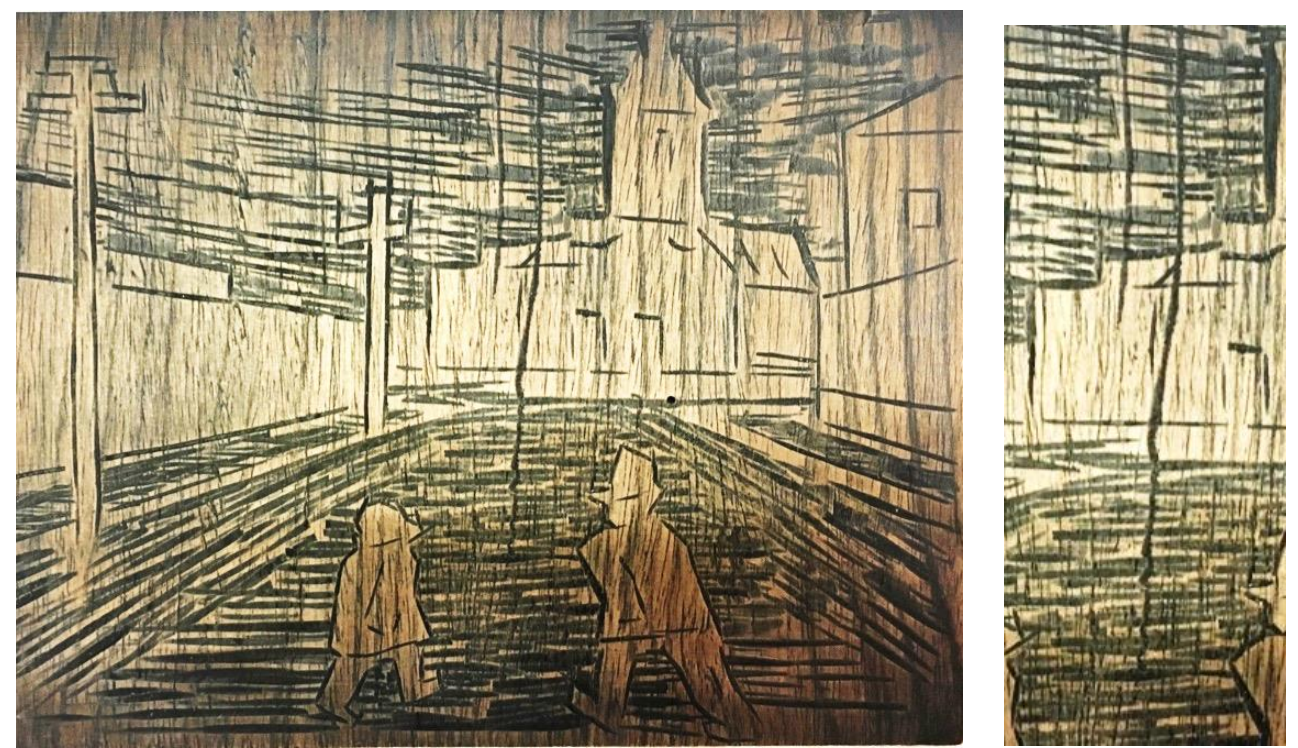

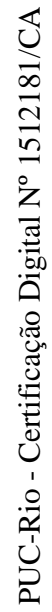

Figura 18: GOELDI, OSWALDO. Luz sobre a praça, 1949. Matriz xilográfica, 15,6 x 21,9 x 0,6 cm, MNBA Detalhe de rachadura na matriz

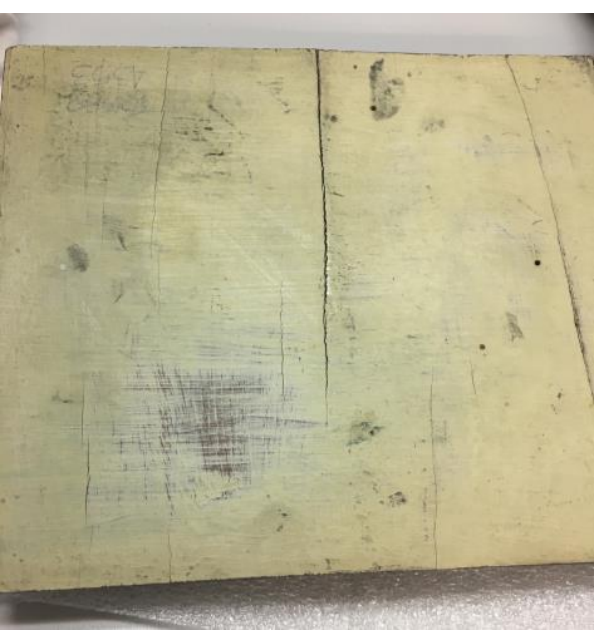

Verso

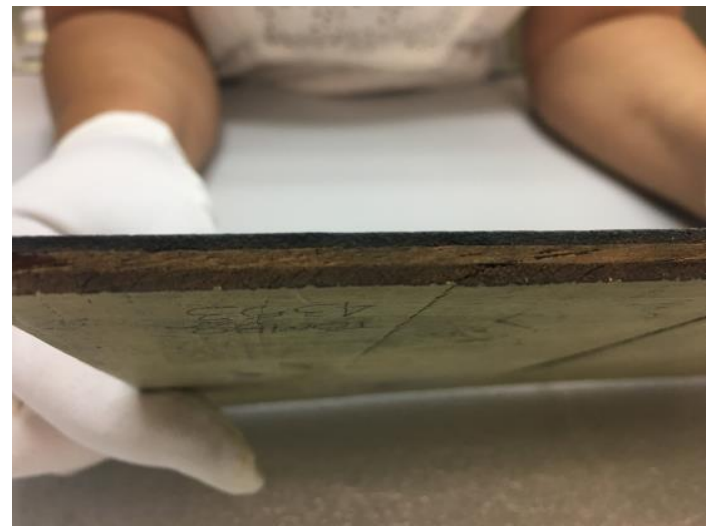

Lateral 


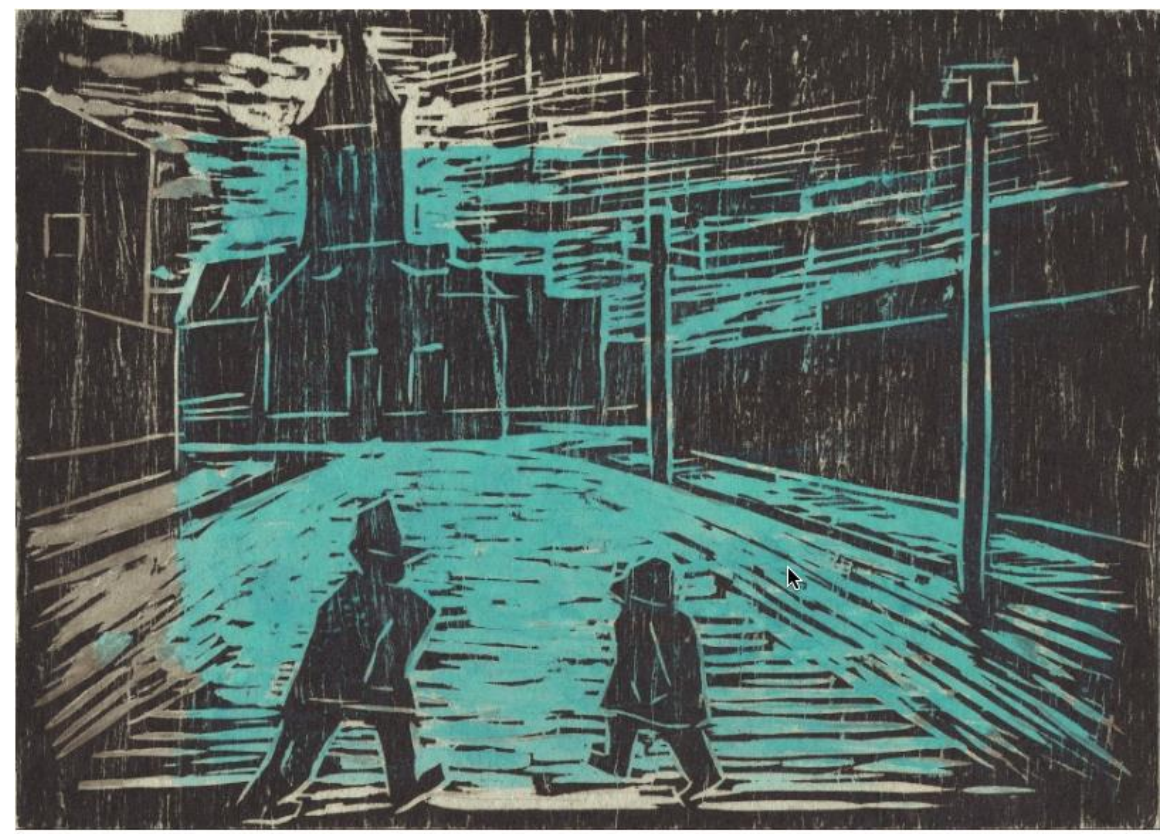

Figura 19: GOELDI, OSWALDO. Luz sobre a praça, 1949. Xilografia a cores, $16,1 \times 21,8 \mathrm{~cm}$.

$\mathrm{Na}$ diversidade de espécies brasileiras, Goeldi encontrava particularidades importantes à construção das formas de sua imaginação. De madeira rígida, a peroba-rosa (Aspydosperma polyneuron) é uma árvore das florestas tropicais que não deixa marcas dos veios na impressão ${ }^{39}$. Com ela, produzia um negro profundo e denso, sem filetes luminosos. O mesmo não se dava com o mogno-da-amazônia e o cedro, que deixavam traços finos. O cedro (Cedrela físsilis), que até hoje é utilizado para escultura e marcenaria, com uma variedade de tons que vão do amarelo ao vermelho, deixava aparentes os pequenos riscos que traziam uma atmosfera de umidade, suavidade ou tensão atribuídos à visualidade das paisagens. A relação com o material era intensa, de natureza sensível, tátil. A madeira precisava ser "sentida" para a devida apropriação de todas as suas possibilidades: "Esta é macia e quente, aquela é dura, resistente ao corte" 40.

\footnotetext{
${ }^{39}$ RIBEIRO, Noemi. Oswaldo Goeldi: mestre visionário. P.10

${ }^{40}$ Entrevista de Oswaldo Goeldi à Revista Visão, São Paulo, 03/03/1961, P.48. Apud RIBEIRO, Noemi. Oswaldo Goeldi: mestre visionário. P. 10.
} 


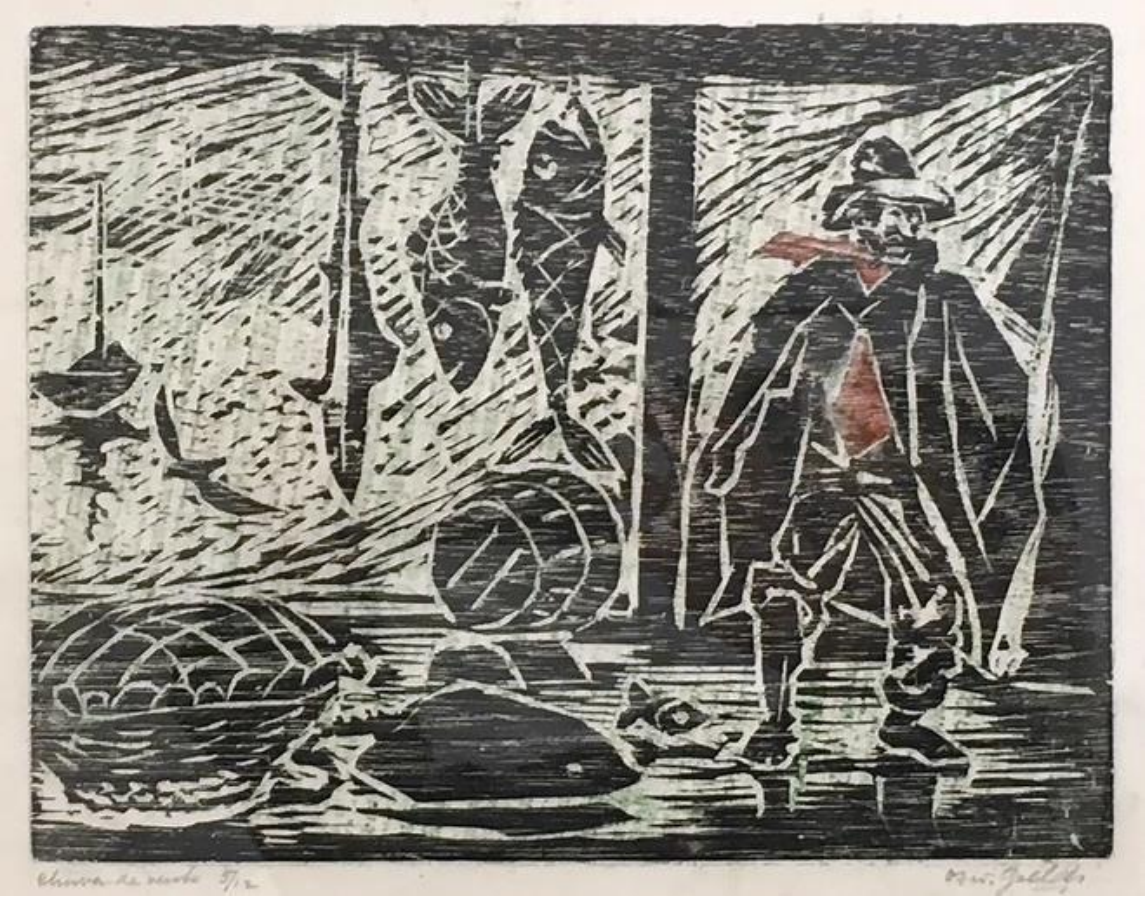

Figura 20: GOELDI, OSWALDO. Chuva de vento ou Ventania, s.d. Xilogravura, $21 \times 27 \mathrm{~cm}$.

Em Chuva de vento ou Ventania (Fig. 20), os sulcos mais grossos ao lado dos veios naturais da madeira formam rajadas de luz de várias espessuras que propiciam a sensação de chuva que se espalha, empurrada pelo vento. Há tensão e percepção acentuada de umidade na cena, podendo-se sentir o piso molhado através da poça d'água refletindo as pernas do pescador, o peixe e os objetos dispostos no solo. É o domínio sobre a matéria dura vencendo sua resistência, e a soberania sobre a técnica, gesto se integrando ao objeto, em uma relação dinâmica entre ferramenta e matéria. Comparando obras de Goeldi e Van Gogh, Rodrigo Naves observa que, em ambos, as estrias invertem o movimento de perspectivação que deveriam criar, como no caso de Corvos sobre o trigal (Fig. 21). ${ }^{41}$ Analisando este mesmo quadro, Meyer Shapiro observa que "as linhas convergentes

\footnotetext{
${ }^{41}$ NAVES, Rodrigo. Goeldi. Espaços da arte brasileira. São Paulo: Cosac \& Naify Edições, 1999. P.24.
} 
tornaram-se caminhos divergentes" ${ }^{42}$, impossibilitando o nosso olhar de chegar ao fundo. Os corvos partem do horizonte para o primeiro plano, invertendo ainda mais o caminho natural da visão que sempre tem a expectativa de atravessar o quadro. Em Goeldi, tanto os fios raspados como os veios naturais da madeira, que compõem as estrias luminosas, forçam a passagem através das massas escuras, empurrando a cena para frente e reduzindo a profundidade. A chuva em todas as direções e o pássaro que voa na direção do observador, assim como os corvos de Van Gogh, suscitam a sensação do barco mais próximo do que realmente está e impulsionam a imagem em nosso sentido. As cores do pescador atraem mais o olhar deixando o barco literalmente à deriva, envolvido pela tempestade.

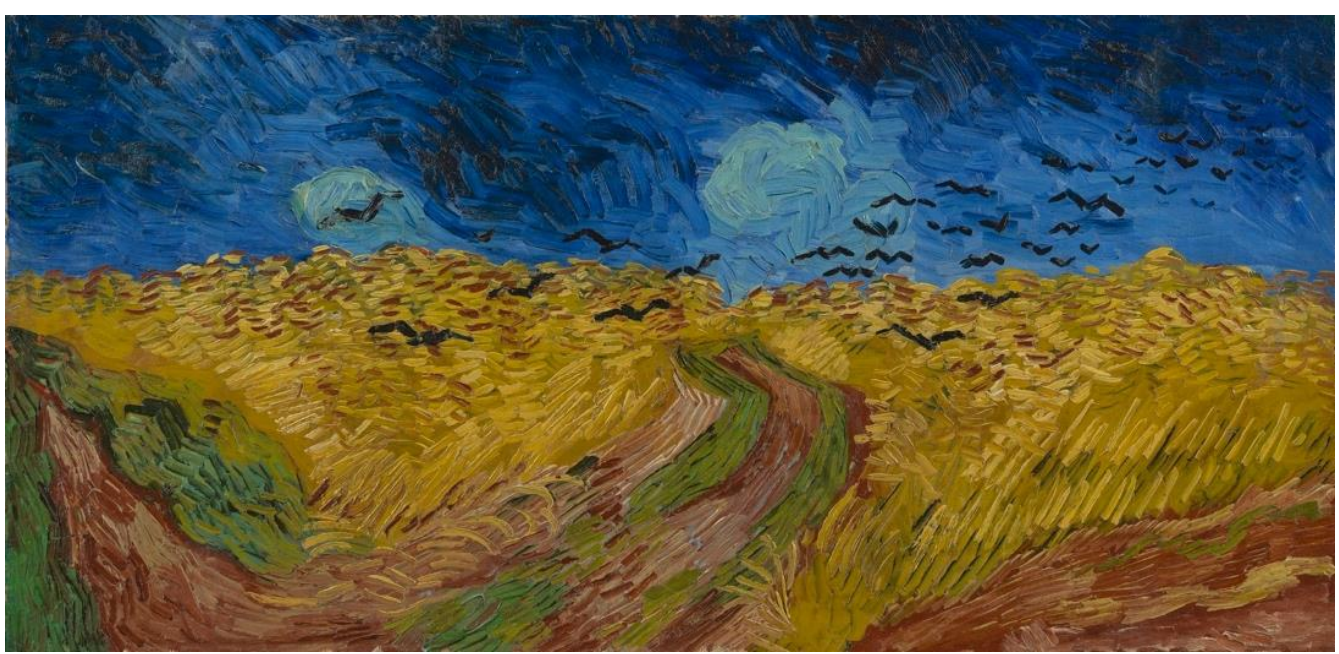

Figura 21: VAN GOGH, VINCENT. Corvos sobre o trigal, 1890. Óleo sobre tela, $50,5 \times 103 \mathrm{~cm}$.

Há na madeira uma espécie de hierarquia da dureza, onde áreas externas mais tenras convivem com cernes mais endurecidos. $\mathrm{O}$ artesão precisa vencer a solidez pois, entre partes mais ou menos firmes, há muito mais do que um contraste de cores. Na imaginação material e dinâmica, os nós suscitam uma força interna que deseja a vitória. A hostilidade propõe a liberação de um tipo de ira, que não está só na força das mãos, mas em todo o ser. A madeira passa a ser dominada pela rigidez da cólera. Resistência e furor passam a estar vinculados diretamente.

\footnotetext{
${ }^{42}$ SHAPIRO, Meyer. A arte moderna dos séculos XIX e XX. P. 135.
} 
No cotidiano do ofício, Goeldi conseguia concretizar a adequação da madeira sólida aos devaneios criativos. Orientado à busca obsessiva pela perfeição da forma, foi tornando a artesania da impressão também um impulso expressivo. O desenho e a goivagem poderiam estar perfeitos, mas se a impressão não estivesse impecavelmente de acordo com o imaginado, o trabalho era refeito quantas vezes fosse necessário. Por meio de rigorosa experimentação técnica, a inventividade estava associada ao energetismo ${ }^{43}$ de uma imaginação das forças, onde a criação e o processo artesanal da xilogravura, se integravam como força expressiva. Reis Jr. conseguiu descrever esses momentos de intensa dedicação ao ritual da gravação:

"Trabalho paciente que o absorvia, procura exaustiva para que as emoções sentimentais encontrassem seus equivalentes plásticos, transformando-se em fonte de emoções estéticas, e que se prolongava pelas noites adentro, sustentado somente pela febre criadora. Nenhum derivativo para encurtar a duração das horas". ${ }^{4}$

Assim trabalhava por noites a fio, na solitude alimentada por flama perfeccionista e intransigente. Para a filosofia bachelardiana, o caráter do indivíduo se confirma nos momentos de total solidão, muito favoráveis às proezas imaginárias. Ao abandonar os outros homens e mergulhar fundo em seus devaneios, o ser humano consegue ver o mundo com mais clareza. É devolvido à natureza, às suas potências geradoras e à função de transformação material. $\mathrm{Na}$ solidão ativa, quer manipular a matéria e transformá-la, deixando de ser um simples filósofo diante do universo, agindo como uma força contra a substância das coisas.

A gravura comprometia recursos para maior alcance do público, exigindo de Goeldi mais "acuidade compreensiva" 45 . As ilustrações de jornais e revistas ajudavam, de certa forma, a romper com o marginalismo, garantindo o êxito da obra que desenvolvia simultaneamente, além de mantê-lo financeiramente. Se a matéria pode ser vista como um espelho do ser, que enfatiza as potências individuais, os devaneios, por ela adquiridos, modificam a dimensão das faculdades particulares e criam a ilusão de onipotência no sujeito. Goeldi não

\footnotetext{
${ }^{43}$ Doutrina filosófica de W. Oswald (químico alemão, 1853-1932) e outros para quem os elementos da realidade, tanto material como espiritual, são energia. Defendia a unidade das forças da natureza.

${ }^{44}$ REIS JÚNIOR, José Maria dos. Goeldi. P.47.

${ }^{45}$ Idem. P. 35 .
} 
realizava nenhum trabalho superficialmente, mesmo o trabalho do dia a dia era realizado com seriedade quase obsessiva, considerando cada assunto para ilustrar "como um problema a lhe pedir solução" 46 . Por questões éticas, era contra o exibicionismo, o público deveria se interessar espontaneamente pelo seu trabalho.

Nos vocabulários grego e latino, com todo seu esplendor clássico, não havia uma palavra que representasse o que entendemos por belas-artes. As palavras ars e techné eram empregadas não só para a arte que conhecemos hoje, como também incorporava processos artesanais de forma abrangente, tão diversos quanto escultura, fabricação de sapatos, música, carpintaria, pintura de vasos, poesia ou culinária. O processo técnico era a parte primordial do processo artístico, concedendo à artesania o papel da arte, não separando os diferentes saberes. Nesta forma antiga de pensamento, "a oposição à arte humana não era o artesanato, mas a natureza". ${ }^{47}$ Mais além, mesmo com a distinção entre artes e ofícios na criação das academias de arte renascentistas, a ideia de "fazer" ainda era tremendamente valorizada, as encomendas eram especificadas por compradores e o artista era também um "executor" de uma arte coletiva. A autonomia e individualização do artista começou a se esboçar apenas no século XVIII, quando há a separação entre belas-artes e artesanato/artes populares. O artista se torna "o criador de obras de belas-artes", enquanto o artesão é "um mero fazedor de algo útil ou divertido" 48 . O Pós-Impressionismo e o Expressionismo retomaram a concepção do "fazer" da técnica artesanal que remete o homem às suas origens artísticas, valorizando práticas como a gravura.

As origens da gravura remontam à China do século VI, mas só foram disseminadas no Ocidente com o Renascimento, representando o início da primeira era de reprodutibilidade na arte europeia. Com o aprimoramento de técnicas a metal e a possibilidade de multiplicação das imagens, a gravura era um importante instrumento de divulgação de trabalhos artísticos, produzida já em larga escala nos ateliês europeus do século XVII. Questionamentos quanto à autenticidade do processo de reprodução, na época realizado a várias mãos,

\footnotetext{
${ }^{46}$ Idem. P.36

${ }^{47}$ SHINER, Larry. The Invention of Art: a cultural history. Chicago: The University of Chicago Press, 2001. P.5.

${ }^{48}$ Idem, ibidem.
} 
entravam em pauta. Dürer foi o principal representante deste período e um dos pioneiros no uso da água-forte, deixando em torno de 250 xilogravuras e mais de 100 gravuras em metal ${ }^{49}$. A profícua fase inicial da gravura ocidental foi ultrapassada apenas pela invenção das grandes máquinas fotomecânicas em meados dos anos 1800. Por um processo fotográfico que gerava uma matriz a partir de um original, estes equipamentos operavam com a reprodução de cópias impressas em grande escala. A realidade fotomecânica, além do cinema, foi preocupação de Walter Benjamim em seu célebre ensaio A obra de arte na era de sua reprodutibilidade técnica ${ }^{50}$, quando a Europa era invadida por cópias de toda a ordem.

A técnica da xilogravura passa por uma intensa revitalização no final do século XIX, a partir das experiências de Gauguin e Munch. Assim como Goeldi, esses artistas não recorriam a gravadores ou impressores, faziam o trabalho experimentando todas as etapas do processo artesanal. Gauguin alterava e aproveitava a textura dos blocos, rebaixando algumas partes para que tivessem menos tinta e ficassem marcadas na impressão, variando a qualidade e quantidade de cores e papéis. Munch também inovava com técnicas não convencionais. Serrava as matrizes, entintava as peças individualmente, imprimia como um todo, de uma só vez. ${ }^{51}$ A experimentação da impressão em várias cores era rara na época, também incomum era a mesma cena experimentada em técnicas diversas, modificando a imagem de acordo com o tipo de gravação, do detalhamento do metal à rusticidade da madeira.

Nos parâmetros gerais da História da Arte, Van Gogh está associado a um "estilo" de pincelada expressiva bastante carregada pela aplicação espessa da tinta. Munch é conhecido pelo modelo de pinceladas ritmicamente onduladas, com tinta diluída e pingos deixados aleatoriamente na obra. Mas Van Gogh experimentou diversas técnicas de pintura, passando pelo neoimpressionismo pontilhista e o desvanecimento lautrequiano da cor, com pinceladas finas e opacas. A inclinação natural pela aplicação da tinta em camadas grossas foi

\footnotetext{
${ }^{49}$ MARTINS, Carlos; PICCOLI, Valéria; TJABBES, Pieter, curadoria. Impressões originais: a gravura desde o século XV. P.21.

50 BENJAMIN, Walter. A obra de arte na era da sua reprodutibilidade técnica. Magia e técnica, arte e política: ensaios sobre literatura e história da cultura.

${ }^{51}$ CABO, Sheila. Goeldi, modernidade extraviada. P.64.
} 
reforçada pela rudeza que encontrou na pintura de Monticelli e a liberdade e espontaneidade nas cores do sul da França que o moveram ao retorno ao emplastro da tinta viva e vibrátil, que foi marca da sua poética. Tanto Gauguin como Munch demonstravam certo descontentamento com a maneira como Van Gogh manipulava os pincéis, mesmo assim, o artista norueguês experimentou vários tipos de pinceladas, de tamanho e espessuras diferentes, muitas vezes utilizando-as na mesma pintura. Munch preferia uma aparência pictórica um tanto inacabada, contudo, é visível a influência que Van Gogh exerceu em algumas de suas obras, como Primavera na Floresta Elm (Fig. 22). Essa espessura de pincelada van goghiana dando volume e vida própria aos objetos de cada cena, priorizando elementos em detrimento de outros com o claro objetivo de manipular visadas, foi também utilizada por Goeldi no desenho e no processo de goivagem de suas gravuras.

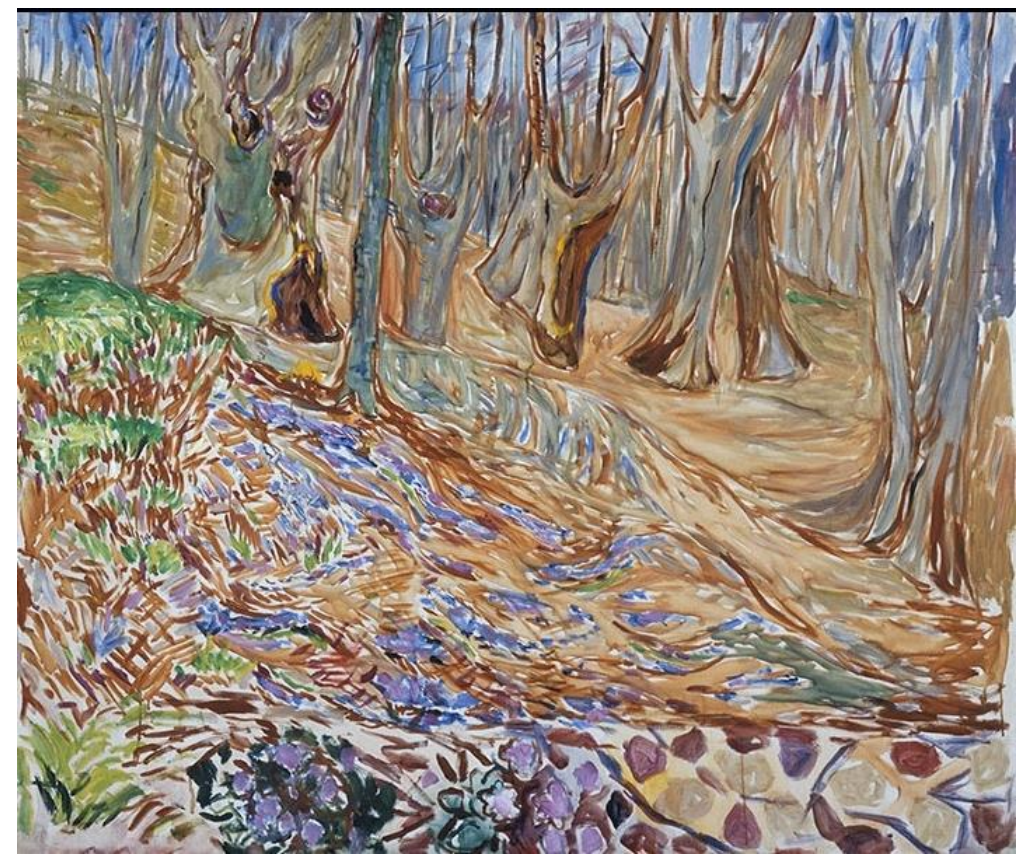

Figura 22: MUNCH, E. Primavera na Floresta Elm, 1923. Óleo sobre tela, 109 x $130 \mathrm{~cm}$.

A atitude de experimentação destes artistas poderia chegar a extremos como deixar as telas expostas ao tempo, como Munch o fazia, com o objetivo de integrar eventualidades naturais à superfície, como a chuva. Manchas de água, gotas e rachaduras são visíveis em algumas obras deste artista que chegou a ser considerado pioneiro em experimentações que priorizavam o processo em relação 
ao acabamento. Munch e Van Gogh ao tentarem alcançar uma superfície expressiva que combinasse e reforçasse o uso da cor, da linha e da composição, influenciaram toda uma geração de artistas, das vanguardas europeias às neovanguardas americanas.

Em Goeldi, a influência em tornar a superfície da madeira expressiva é inequívoca, principalmente no desenvolvimento do método de entalhe da matriz. Inicialmente, as goivas eram trabalhadas mais superficialmente, com estrias finas, agitadas. Mais tarde, os rasgos se intensificaram e se aprofundaram como "pinceladas" grossas de tinta emplastrada. Ao vencer os dilemas da resistência da matéria, conseguia superar a própria natureza da madeira. Os progressos nos processos técnicos de gravação e impressão, no uso da cor e da perspectivação invertida buscando tímida planaridade, apesar da presença da caixa cênica, nos remetem à experimentação que extrapola os limites da criação, do desenho e da imagem. A força expressiva em Goeldi se dava em todo o processo xilográfico, da concepção ao papel impresso, numa combinação de desenho, goivagem, cores e composição, que se integram em um sopro criativo.

Goeldi tentou realizar outras técnicas de gravação nos anos 1950, como água-forte e água-tinta, mas a poética do artista era mesmo a xilogravura ${ }^{52}$. Os duelos que travava com a madeira eram precisamente calculados. Desenhava muitas vezes a mesma cena, preparava a matriz, criava suas próprias goivas, projetava ataques meticulosos à peça e realizava várias provas até que o resultado fosse o almejado. O processo de criação e impressão poderia levar meses, anos: "Sei o que faço, sei quando o meu trabalho é bom, quando ele falhou, quando é só talentoso, quando é puramente mau. Quando acho ruim, cem amigos podem achar bom, não me deixo convencer e chego até a ficar com raiva de tais amigos."

\footnotetext{
${ }^{52}$ SIQUEIRA, Vera Beatriz. Cálculo da Expressão. P.16.

${ }^{53}$ GOELDI, Oswaldo. Notas íntimas. Apud REIS JÚNIOR, José Maria dos. Goeldi. P. 47.
} 


\title{
2.3. \\ A experimentação cromática
}

"A cor é um meio de exercer influência direta sobre a alma.
A cor é a tecla. Os olhos são o martelo.
A alma é o piano com suas várias cordas.
O artista é a mão que, tocando esta ou aquela
tecla com um propósito definido,
faz vibrar a alma humana."54
Wassily Kandinsky

O caminho expressivo de Goeldi através da cor, compreendido pela teoria do onirismo do trabalho fascinante de Bachelard, reuniu duas das grandes funções psíquicas do homem: imaginação e vontade. Percurso construído gradativamente por desafios técnicos, com perspectivas que se abriam à aspiração do uso das cores (vontade) como elemento plástico de expressão (imaginação). Mesmo com todas as aquarelas e desenhos em cores que constavam em seu portfolio, o artista atribuía a dificuldade tática ao fato de não ter sido pintor, e, portanto, ter a experiência com a policromia reduzida ${ }^{55}$. O duelo com as técnicas de gravação a cores excedia mais uma vez os limites da experimentação entrando no âmbito da obstinação quase obcecada para chegar à cor gráfica:

\begin{abstract}
"Quantas vezes, madrugada alta, acompanhei a consciência meticulosa do seu trabalho em busca dessa solução! Quantas cópias laboriosas eu o vi amarfanhar porque o vermelho não alcançara a vibração desejada ou porque o verde ou o azul não corresponderam à profundidade pretendida ou, então, porque após longos e pacientes estudos, resolveu alterar a própria matriz, acentuando mais um corte ou aumentando o espaço entre duas superfícies". ${ }^{56}$
\end{abstract}

Goeldi experimentou o uso da cor na xilogravura pela primeira vez no ateliê do artista suíço Hermann Kümmerly, em sua visita à Berna, em 1930. Imprimiu uma cor sobrepondo outra e definiu as figuras com pinceladas de guache preto ${ }^{57}$, mas o resultado ficou aquém do que idealizava. Em 1933, escreve a Kubin sobre um conjunto de desenhos de animais da fauna brasileira: "Nunca consegui

\footnotetext{
${ }^{54}$ KANDISKY, Wassily. O efeito da cor. In: Chipp, Herschel B. (Org.), Teorias da arte moderna. P. 153.

${ }^{55}$ Entrevista de Oswaldo Goeldi a Ferreira Gullar. Suplemento Dominical do Jornal do Brasil, em 12/01/1957. In: BRITO, Ronaldo. Oswaldo Goeldi. Coordenação de Silvia Roesler, Pg. 211.

${ }^{56}$ REIS JÚNIOR, José Maria dos. Goeldi. P.46

${ }^{57}$ RIBEIRO, Noemi. Oswaldo Goeldi: mestre visionário. P.10
} 
produzir desenhos tão bons. As técnicas são diversas: carvão, sépia, traço e tom, nanquim, tinta neutra e cinábrio (os macacos uivantes são vermelho-fogo)."

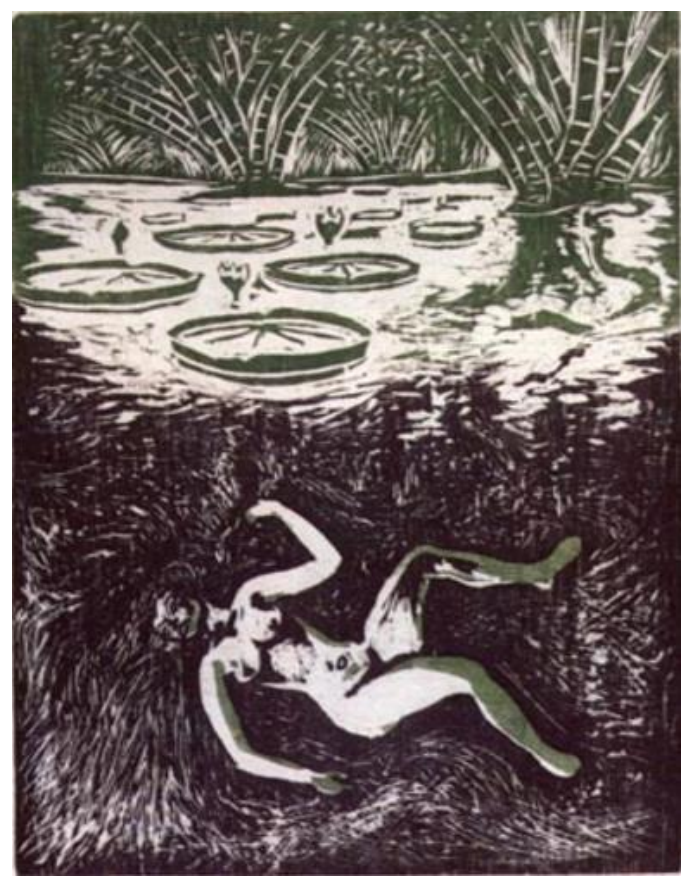

Figura 23: GOELDI, OSWALDO. Uiara, Ilustração para Cobra Norato, 1937.

Xilogravura a cores, $27,4 \times 20,7 \mathrm{~cm}$.

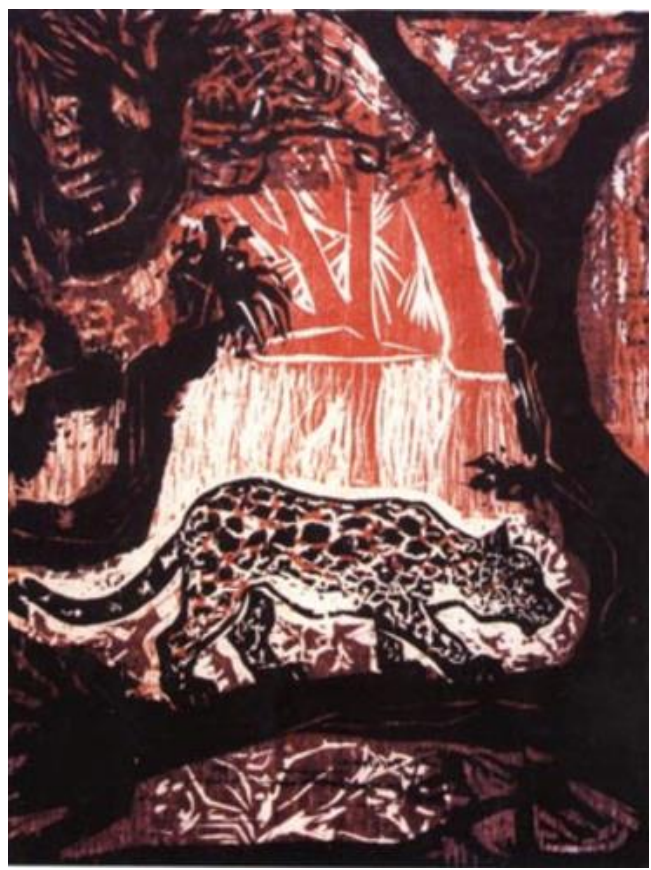

Figura 24: GOELDI, OSWALDO. Onça, Ilustração para Cobra Norato, 1937. Xilogravura a cores, $27,5 \times 20,7 \mathrm{~cm}$.

\footnotetext{
${ }^{58}$ Carta de Goeldi a Kubin, 08/05/1933. In: RIBEIRO, Noemi. Oswaldo Goeldi: um autorretrato. P.170.
} 
A policromia se manifestaria novamente na xilogravura para as ilustrações do livro Cobra Norato (Figs. 23 e 24), de Raul Bopp, em 1937, nas quais o contexto do mundo amazônico e suas lendas demandavam abundantes cores contrariamente aos habituais preto e branco. Utilizando a técnica de diversas matrizes, enquadrou a cor nos limites gráficos como um gravador, "não como um pintor gravando em cores" ${ }^{~} 59$. Em algumas ilustrações, aboliu o preto mantendo o desenho no limiar dos diferentes tingimentos. Goeldi acompanhou a impressão do livro, como faria em casos posteriores, para ter garantida a desejada qualidade nas gravuras. O resultado dos efeitos adquiridos no procedimento escolhido não foi satisfatório, vendo similaridade com a estampagem de tecidos. Uma volta aos primórdios das gravações no Ocidente, ainda no século XIV, quando os blocos de madeira já usados em reprodução de padronagens em tecidos foram aplicados em papel, dando origens às primeiras xilogravuras.

A partir de 1940, passou a incluir cor nas gravuras. A técnica encontrada foi a entintagem múltipla na mesma matriz. As cores eram isoladas e aplicadas com rolos de diversos tamanhos. O papel japonês era colocado sobre o bloco de madeira e, usando colher de pau ou "espátula de osso" "60, imprimia a cópia. Há uma peculiaridade interessante neste processo já que era bem difícil repetir com a mesma exatidão gestual a tiragem de outros exemplares. Nesse aspecto, Goeldi mantinha a "aura" da obra de arte mesmo em um processo de cópias seriais. Em sua teoria sobre a reprodutibilidade técnica, Walter Benjamim nos fala sobre a mudança radical no critério de autenticidade a que se aplicava à produção artística dos modernos processos de reprodução, principalmente referindo-se à impressão fotomecânica, fotografia e cinema. A tiragem de cópias substituiria a existência única pela serial: “O valor único da obra de arte autêntica tem seu fundamento no ritual, no qual teve o seu valor de uso original e primeiro" ${ }^{61}$. A experimentação com as aplicações múltiplas de cor levou à redução do número de cópias das gravuras. Com tiragens limitadas, alguns exemplares coloridos tiveram outras versões de tonalidade, ou também foram impressos em preto e branco, como é o caso de Luz sobre a praça (Fig.19). Goeldi trabalhava no limiar da exploração dos

\footnotetext{
${ }^{59}$ REIS JÚNIOR, José Maria dos. Goeldi, p. 15

${ }^{60}$ Ver nota de rodapé n. 35.

61 BENJAMIN, Walter. A obra de arte na era da sua reprodutibilidade técnica. Magia e técnica, arte e política: ensaios sobre literatura e história da Cultura.
} 
recursos gráficos, imprimindo cada folha com as próprias mãos, sem ajuda da prensa, controlando a pressão da espátula, e transformando a cópia em um paradoxo singular: cada xilogravura tornava-se uma obra única.

Desde os primórdios góticos da gravura, a coloração é aplicada como função decorativa. Mesmo com as inovações difundidas pelo expressionismo alemão, por Gauguin e Munch, essa prática não se modificou plenamente. A partir de Cobra Norato, as experimentações de Goeldi ambicionavam o patamar de uso da cor como elemento expressivo. A policromia foi introduzida discretamente partindo do lirismo dos meios-tons, passando por uma ou duas cores, ora suaves, ora intensas, até chegar ao efeito impactante das últimas obras na década de 1950. Ao suprimir o uso de várias matrizes e direcionar a cor para "expressar a construção e o bom funcionamento das massas pretas" ${ }^{\$ 2}$, procurou chegar a policromia como componente gráfico. O intenso trabalho tinha finalidade de não deixar que o negro limitasse ou aprisionasse outros matizes, tornando-as um elemento decorativo. As soluções ainda não o satisfaziam por estarem as gravuras ainda descritivas, literárias. Aprofundou mais a análise técnica e chegou a Sol Vermelho (Fig. 32), livre do contexto linear, em "massas de cromatismo violento"63 capaz de provocar impacto estético. "Usei a cor com um sentido diferente (do decorativo) meio simbólico, meio fantástico, como na gravura do Guarda-chuva vermelho (ChuvaFig. 34) e na Siri Vermelho (Fig. 31)." 64

Ao analisarmos as matrizes xilográficas, observamos que o processo goeldiano de goivagem sofreu várias transformações, tornando-se evidente a subjugação da matéria em relação à vontade criadora do artista. O material inicialmente "frio, duro e odioso" converte-se em imersão poética a partir de um obstinado duelo meticulosamente calculado. De trabalhos iniciais a derradeiros, clama por atenção o processo de evolução da delimitação das zonas de cor que passaram a ser definidas por sulcos espessos e/ou mais profundos ao redor, destacando as cores pelo contraste com o branco e o preto dos fios. Em Chuva (Fig. 34), o efeito de superposição do guarda-chuva fica mais evidenciado por

\footnotetext{
${ }^{62}$ Entrevista de Oswaldo Goeldi a Ferreira Gullar. Suplemento Dominical do Jornal do Brasil, em 12/01/1957. In: BRITO, Ronaldo. Oswaldo Goeldi. Coordenação de Silvia Roesler, Pg. 211.

${ }^{63}$ REIS JÚNIOR, José Maria dos. Goeldi, P. 15

${ }^{64}$ Idem, ibidem.
} 
espessas estrias do entorno, brancas na impressão, envolvidas pelo negro intenso adjacente. Do mesmo modo, a cor chapada do céu se intensifica com rasgos que reforçam os contornos das árvores, fazendo parte de um plano achatado que impede a passagem do olhar através da cena. A cor vermelha do guarda-chuva é escolhida estrategicamente para capturar o olhar, que novamente não consegue atravessar a cena. A gravação, assim como a entintagem e a impressão exigem um primoroso conhecimento da artesania, que Goeldi exercia religiosamente:

“A precisão com que Goeldi desenha, grava e imprime, e a determinação com que obtém os mais refinados contrastes entre preto e branco é fruto da experimentação e do estudo das possibilidades, inerentes ao material. Alcançar resultados expressivos só foi possível após anos de luta diária com a resistência da madeira, com a aplicação de quem sabe aonde quer chegar, vencendo passo a passo os obstáculos impostos por todas as limitações, tanto as de natureza individual como as exógenas."

A linha com função de contorno é marcante em alguns trabalhos de Van Gogh, como em $O$ salão de dança em Arles (Fig. 25), e Munch, influenciados pelas obras cloisonistas dos artistas que passaram pelo movimento sintetista, como Gauguin, Émile Bernard e Maurice Denis, e pela arte japonesa. O Cloisonismo ${ }^{66}$ pretendia simular na pintura o efeito dos vitrais medievais através de contornos escuros ao redor de zonas de cor intensa. Em O Cristo Amarelo (Fig.26), Gauguin reduziu a imagem a áreas de cores puras, divididas por grandes linhas negras, eliminando gradações sutis de cor sem ter consideração pela perspectiva clássica, rompendo assim com as duas regras mais relevantes da arte pós-renascentista. Mais tarde, caminharia para o Sintetismo onde imperava a economia de meios tendo forma e cor a mesma importância.

\footnotetext{
${ }^{65}$ RIBEIRO, Noemi. Oswaldo Goeldi: mestre visionário. P.15

${ }^{66} \mathrm{O}$ nome Cloisonismo ou Cloisonnisme tem origem na técnica cloisonné de pintura de esmaltes entre contornos de metal, do francês cloison (divisória). Surgiu dentro do movimento sintetista com o objetivo de desenvolver uma síntese das diferentes pesquisas plásticas que aconteciam simultaneamente na França. Segundo Argan, "enquanto Van Gogh, em Arles, descobre o princípio moral, Gauguin descobre o princípio técnico do que virá a ser o Expressionismo. Dá-lhe o nome de cloisonnisme". No Sintetismo-cloisonismo, o sentido da cor é dado pela forma das zonas coloridas, pelo contraste em relação a outras cores e pela relação com a luz. Gauguin continuou sua pesquisa sintetista-simbolista nas ilhas do Pacífico (ARGAN, G.C. Arte Moderna. P.216).
} 


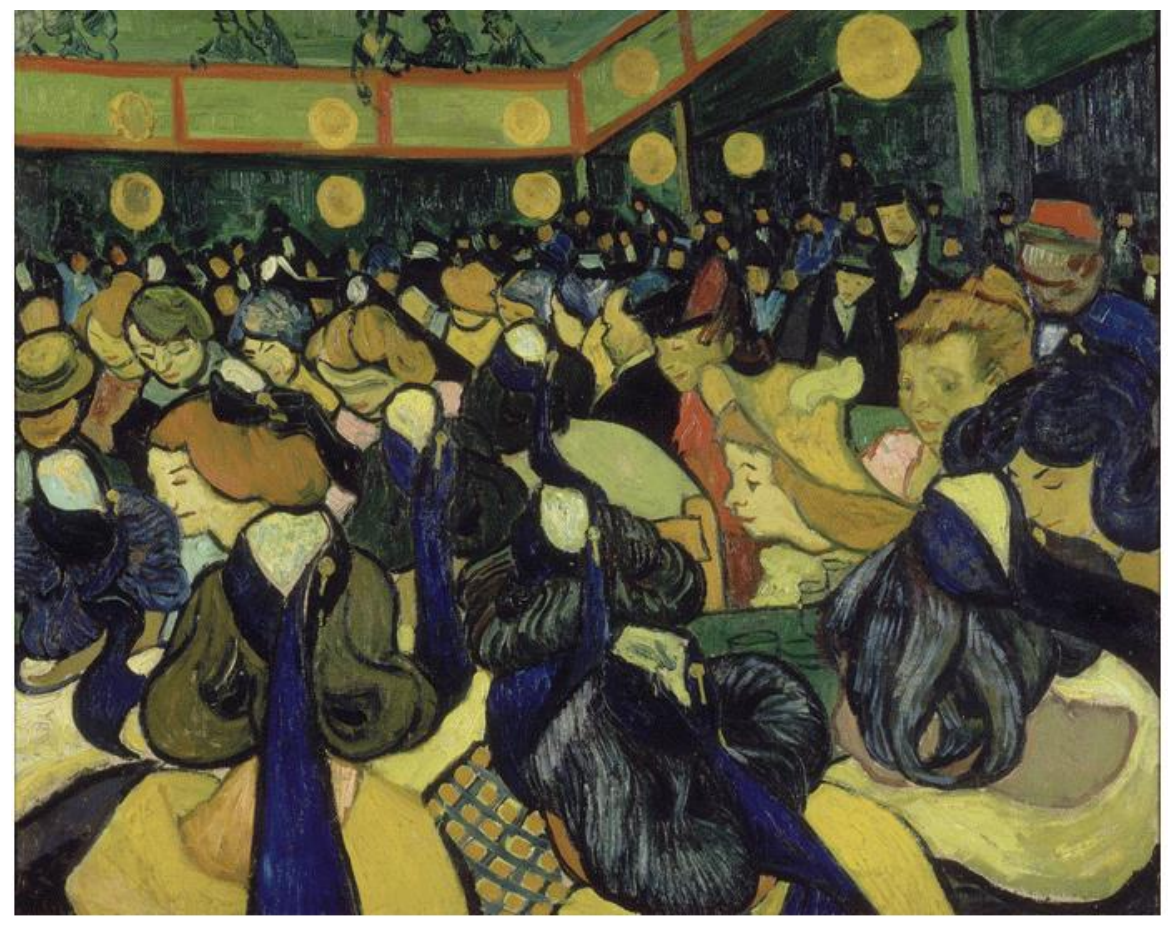

Figura 25: VAN GOGH, VINCENT. O salão de dança em Arles, 1888. Óleo sobre tela, 65 x $81 \mathrm{~cm}$.

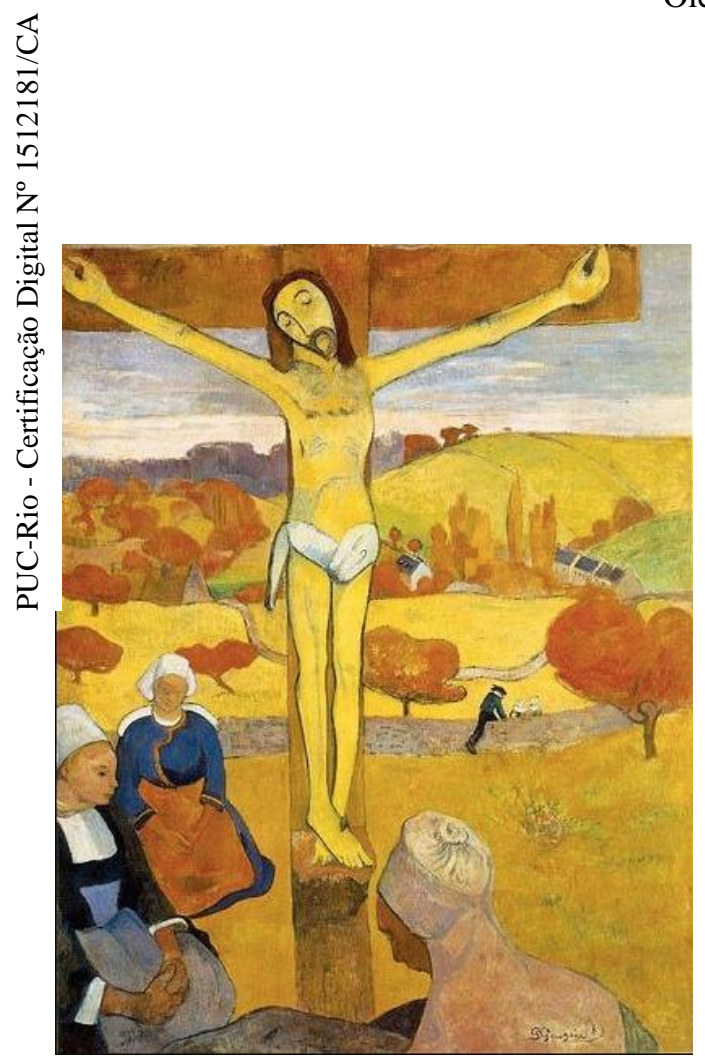

Figura 26: GAUGUIN, PAUL. O Cristo Amarelo, 1889. Óleo sobre tela, $73,3 \times 92 \mathrm{~cm}$.

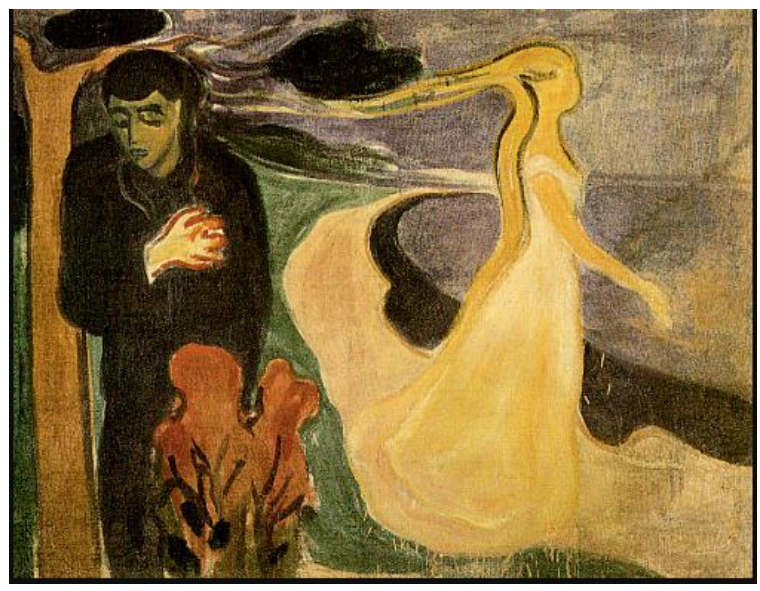

Figura 27: MUNCH, EDVARD. Separação, 1896. Óleo sobre tela, 96 x $127 \mathrm{~cm}$. 


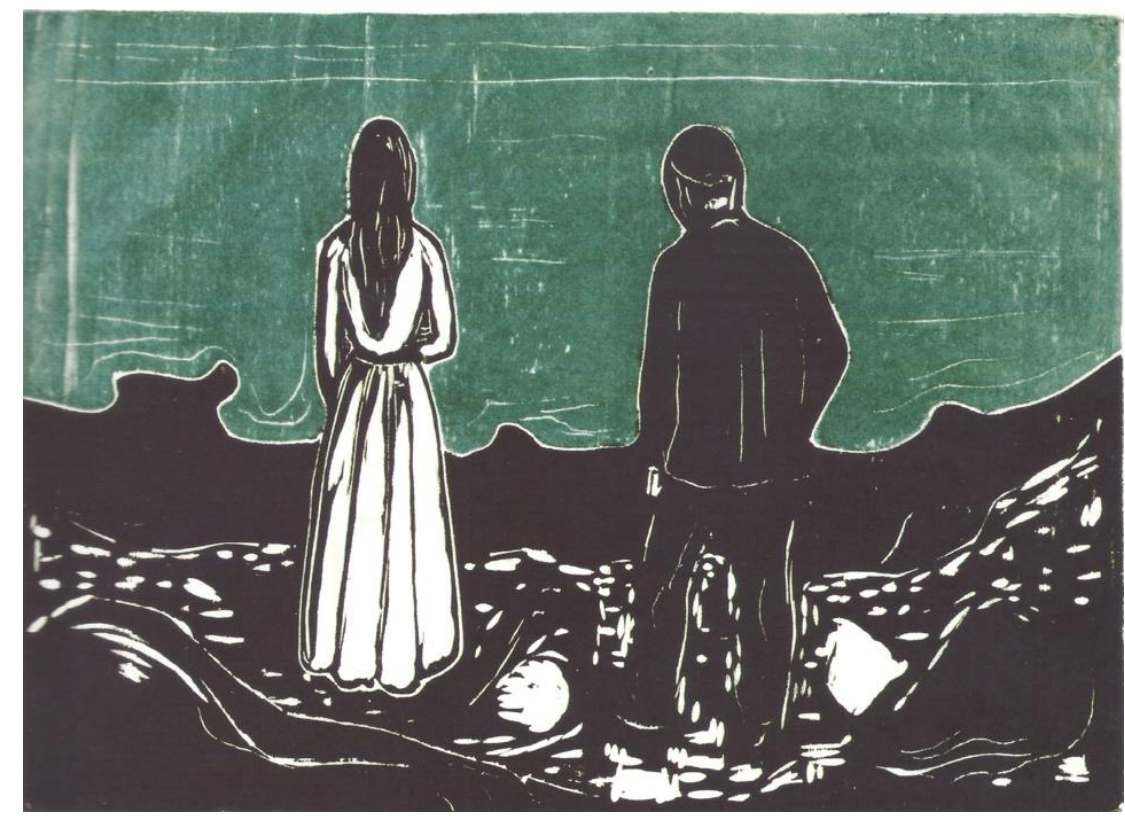

Figura 28: MUNCH, EDVARD. Dois seres humanos, dois solitários, 1899. Xilogravura, $39,3 \times 54,6 \mathrm{~cm}$

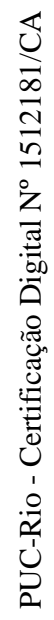

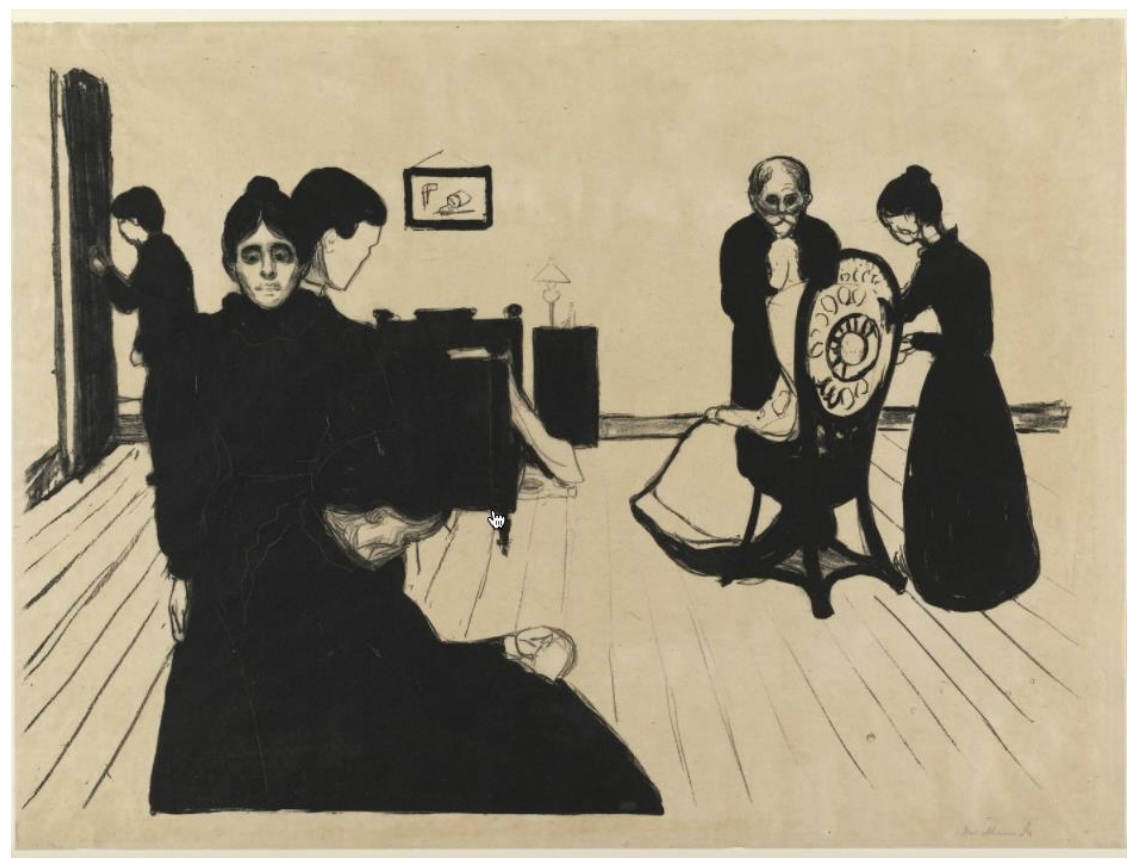

Figura 29: MUNCH, EDVARD. Morte no quarto do doente, 1896. Litogravura, $30,3 \mathrm{~cm}$ x 55,8 cm. 
Em algumas gravuras de Munch, a linha define certo padrão de ondulação rítmica principalmente em cenas litorâneas, como em Dois seres humanos, dois seres solitários (Fig. 28). Em Morte no quarto do doente (Fig. 29), a família é unida na dor pelo contorno que enlaça as pessoas numa única forma. Munch acreditava que as linhas também pudessem descrever energias invisíveis e forças psíquicas como forma de comunicação de uma pessoa com outra. Sobre a pintura Separação (Fig. 27), Munch explicou: "Eu simbolizei a conexão entre o casal separado com a ajuda do longo e ondulado cabelo (...). O cabelo comprido é um tipo de fio de telefone." 67

Em Goeldi, a economia de meios foi gradativa, restringindo o poder descritivo com menos incisões de goiva nos pequenos detalhes do desenho. Os efeitos estéticos da tensão e do movimento passaram a ser mais destacados tanto por uma goivagem mais precisa, com sulcos profundos e definidos, como por veios aparentes da madeira. A evolução desta composição se consolida efetivamente nas gravuras a cores a partir de 1950. Quando analisamos as obras dos últimos anos de Goeldi, onde imperava a satisfação do artista em ter alcançado a cor gráfica imaginada, principalmente em Chuva (Fig. 35), Sol Vermelho (Fig. 33) e Siri Vermelho (Fig. 31), identificamos uma aproximação com o Cloisonismo pós-impressionista como técnica de goivagem. Os contornos se tornam mais intensos, separando as massas de cor por branco ou preto. Nas matrizes, a goiva trabalhou profundamente, sulcando as formas de modo preciso. As zonas coloridas estão mais demarcadas e intensas. Os rasgos profundos facilitavam o isolamento da cor pretendida, sem interferências. Em Chuva (Fig. 35) e Siri Vermelho (Fig.31), a cor foi usada em sentido "meio simbólico, meio fantástico". ${ }^{68}$ Sem a intenção de remeter a vitrais, este processo pode ter sido a fórmula encontrada para solucionar a angústia goeldiana com a cor, separando bem as massas tonais por rasgos que na impressão se dispersavam e ficavam mais suaves, não remetendo a nenhum tipo de delimitação visual. Porém, através de contornos firmes e contrastes precisos, as cores falavam por si, expressavam independentemente histórias e conflitos. Não eram atributos decorativos, outorgavam expressão pelo furor cromático:

\footnotetext{
${ }^{67}$ MUNCH, E. Apud: LLOYD, Jill. Munch: Van Gogh. P.134.

${ }^{68}$ Entrevista de Oswaldo Goeldi a Ferreira Gullar. Suplemento Dominical do Jornal do Brasil, em 12/01/1957. In: BRITO, Ronaldo. Oswaldo Goeldi. Coordenação de Silvia Roesler, Pg. 211.
} 
"Essa nova maneira de trabalhar com a cor desperta e fortalece a minha fantasia e o misterioso aparece em nova forma. (...) Oscilações de sentimento escondidas e que, através de meios técnicos ainda desconhecidos, se revelam"69.

O sentido "meio simbólico, meio fantástico" parece inequívoco quanto ao uso da cor vermelha, mesmo em obras mais antigas, como Rua Molhada (Fig.44) e Tarde (Fig.30). Os elementos, isolados em um colorido chapado meio misterioso, se sobrepõem à superfície negra dando ao ambiente o tom de estranhamento que se quer expressar. Em Tarde (Fig.30), a sensação de vazio opressivo e solidão que o sol em vermelho e seus reflexos proporcionam jamais teria a mesma intensidade somente por contrastes em preto e branco. A bandeira flamulante que salta à superfície em Rua Molhada (Fig.44) produz a inversão perspéctica que lançará o olhar contra o poste no primeiro plano, nos aprisionando no espaço onde tudo parece perdido e abandonado. Em Chuva (Fig. 34), a combinação de contornos brancos, massas negras e riscos no guarda-chuva, deslocam o vermelho em sobreposição de forma que o entorno da cena parece se conter em um único plano achatado, onde massas negras em contraste com a cor verde chapada dissolvem o ponto de fuga. Ao investigar o fenômeno cromático, tentando preservar o sentido gráfico sem abrir mão do elemento simbólico, Goeldi alcança uma formulação de autonomia da $\operatorname{cor}^{70}$. A cor não só causa o estranhamento da percepção visual ao ser elaborada como signo, mais do que expressar o simbólico, produz o impacto visual imediato à maneira dos cartazes expressionistas $^{71}$.

As inovações técnicas permitiram produzir gravuras em cores sem qualquer prejuízo de sua natureza específica, pelo contrário, intensificando seu potencial estético. Assim, apresentou seus trabalhos na Bienal Interamericana do México, em 1960, obtendo o grande prêmio internacional de gravura, em um país com significativa tradição em artes gráficas. "Todo artista realmente criador inova, e

\footnotetext{
${ }^{69}$ Carta de Goeldi a Kubin, 10/04/1952. In: RIBEIRO, Noemi. Oswaldo Goeldi: um autorretrato. P. 178.

${ }^{70}$ CASTRO, Felipe Süssekind Viveiros de. Cor gráfica: a experiência cromática na obra de Goeldi. Dissertação de Mestrado. Rio de Janeiro: PUC-Rio, 2000.

${ }^{71}$ BRITO, Ronaldo. Oswaldo Goeldi, Chuva. Rio de Janeiro: IMS, 2011.
} 
isso porque ele amplia seus meios de expressão. Só essa inovação é legítima - a inovação que é ditada por uma necessidade interior". ${ }^{72}$

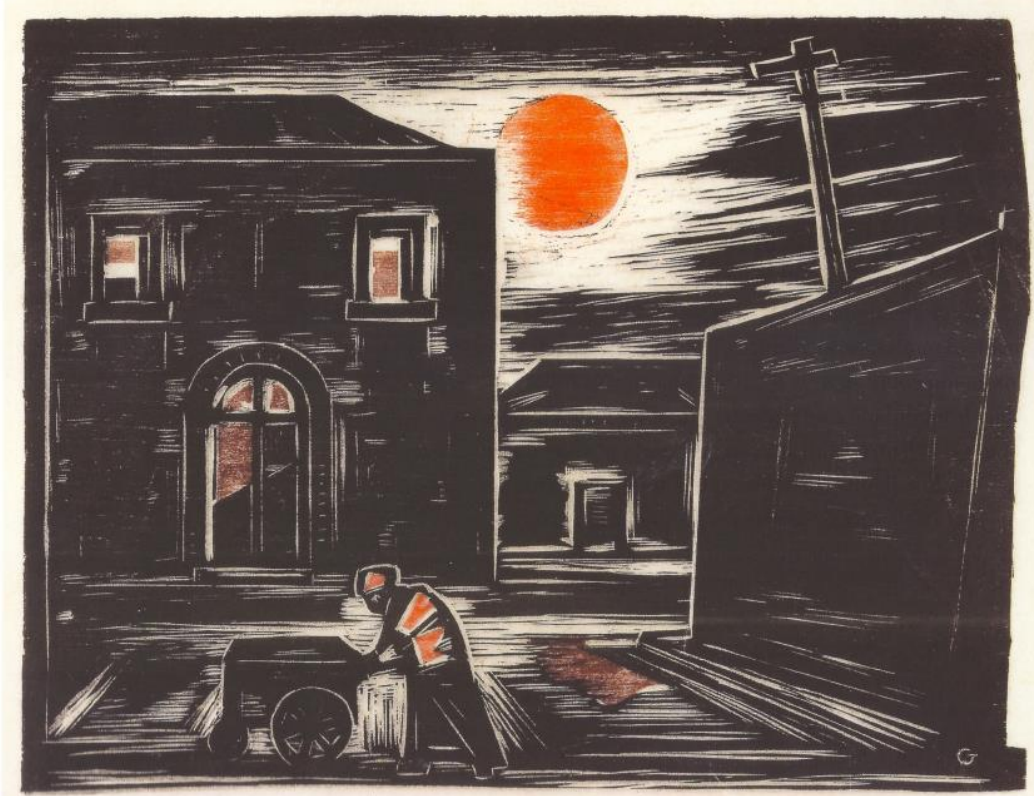

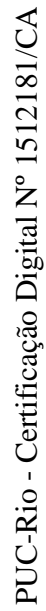

Figura 30: GOELDI, OSWALDO. Tarde, 1954.

Xilogravura, $20,5 \times 26,5 \mathrm{~cm}$.

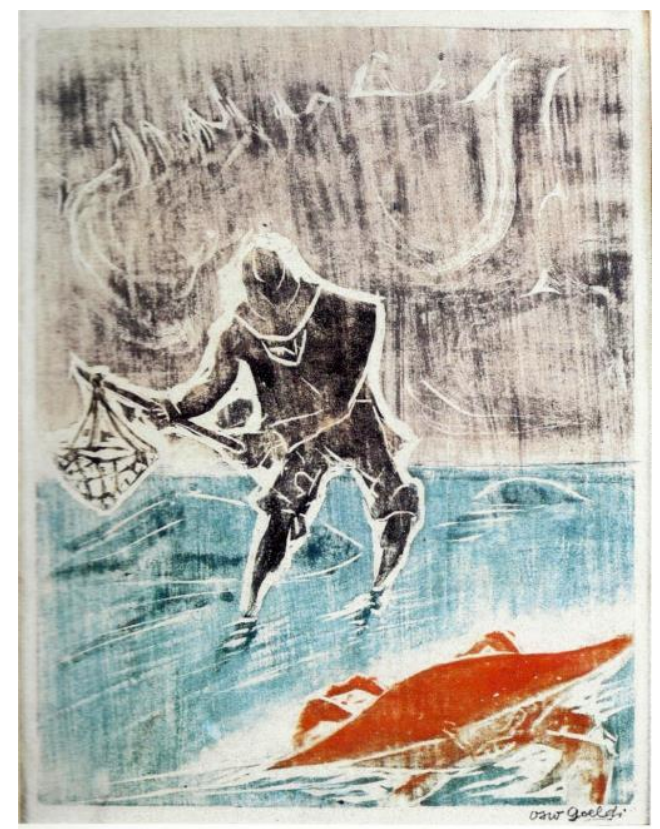

Figura 31 GOELDI, OSWALDO. Sem título (Siri), 1955. Xilogravura, 29,9 x 39,6 cm.

\footnotetext{
${ }^{72}$ Entrevista de Oswaldo Goeldi a Ferreira Gullar. Suplemento Dominical do Jornal do Brasil,
} em 12/01/1957. In: BRITO, Ronaldo. Oswaldo Goeldi. Coordenação de Silvia Roesler. Pg. 208. 


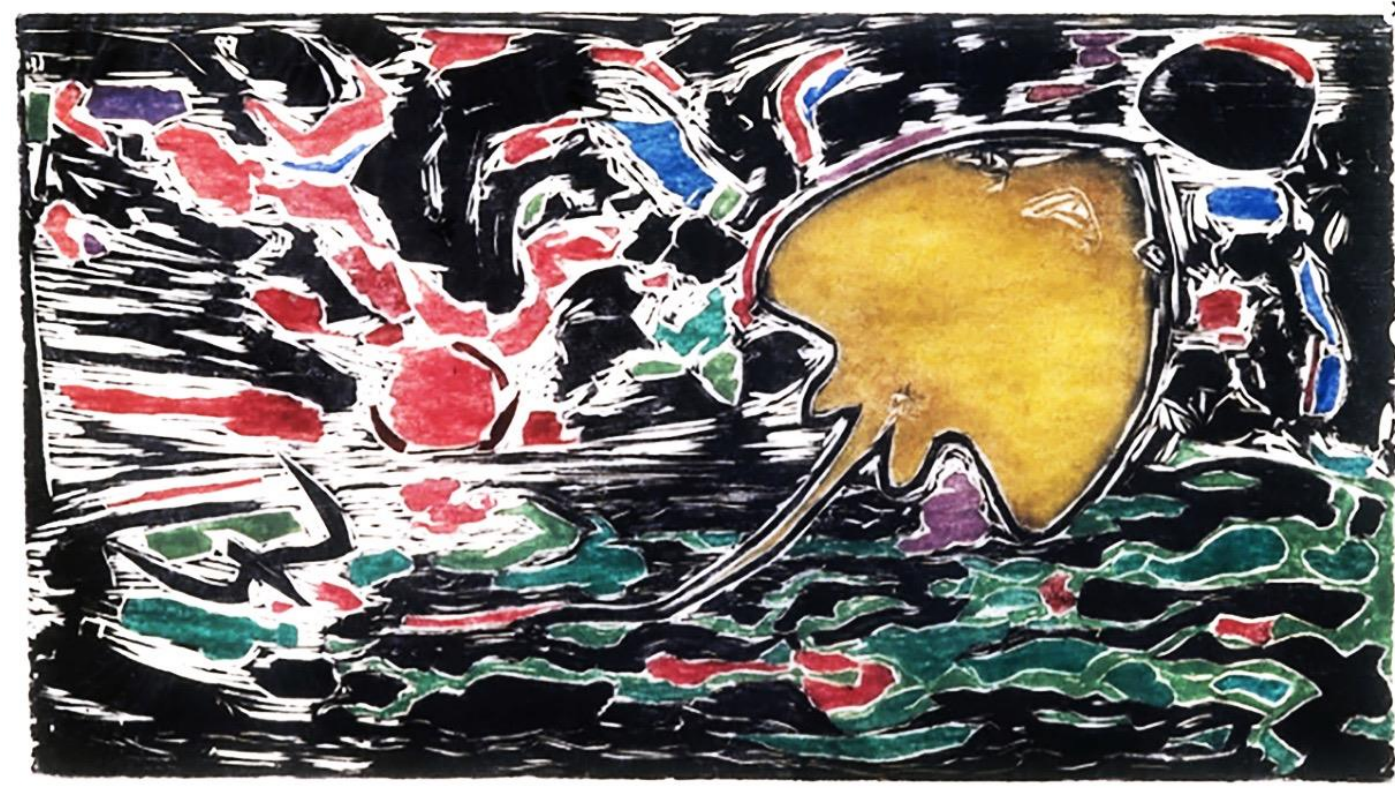

Figura 32: GOELDI, OSWALDO. Sol Vermelho, 1957. Xilogravura, 23 x $41,1 \mathrm{~cm}$.

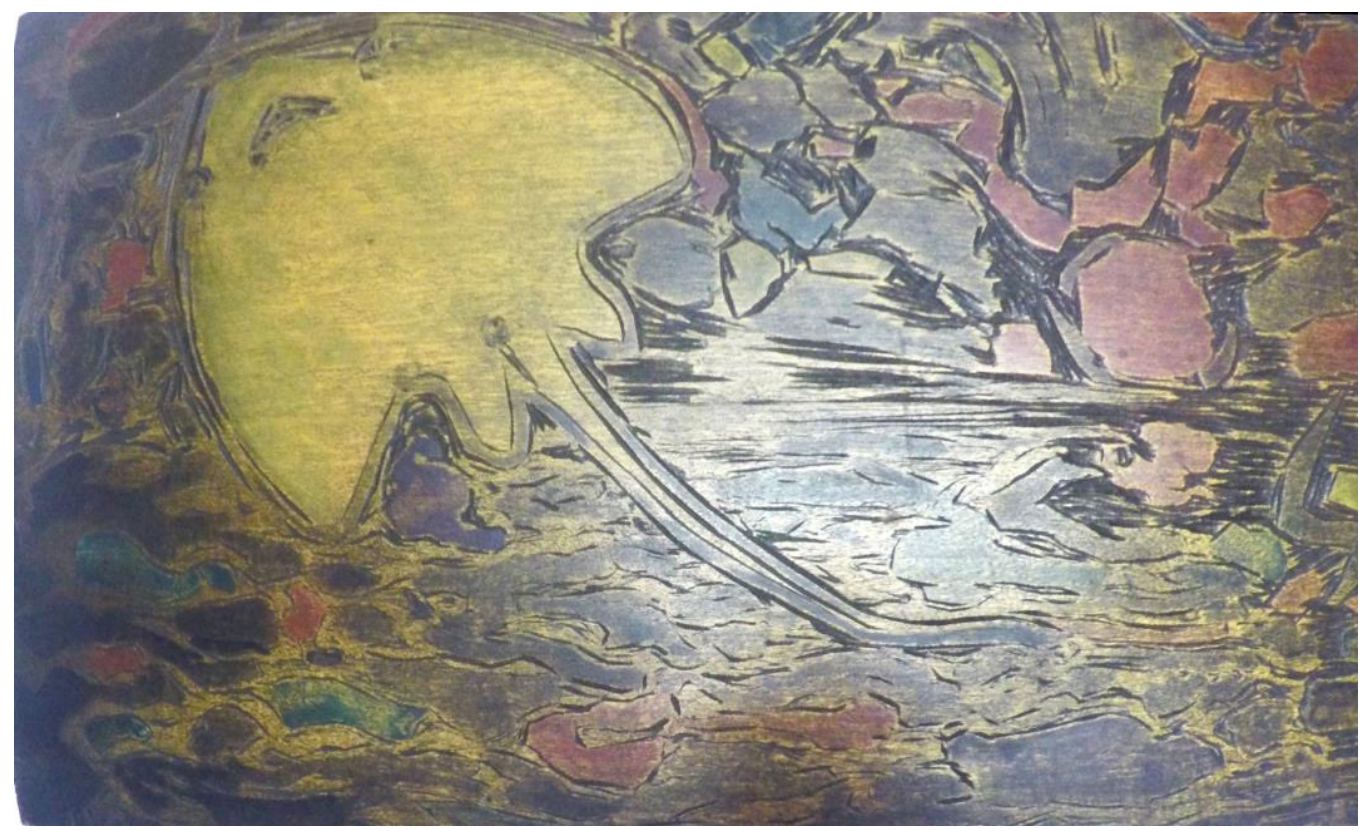

Figura 33: GOELDI, OSWALDO. Sol Vermelho, 1955.

Matriz xilográfica, 23 x 41,2 x 1,3 cm, MNBA. 


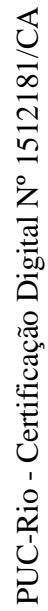

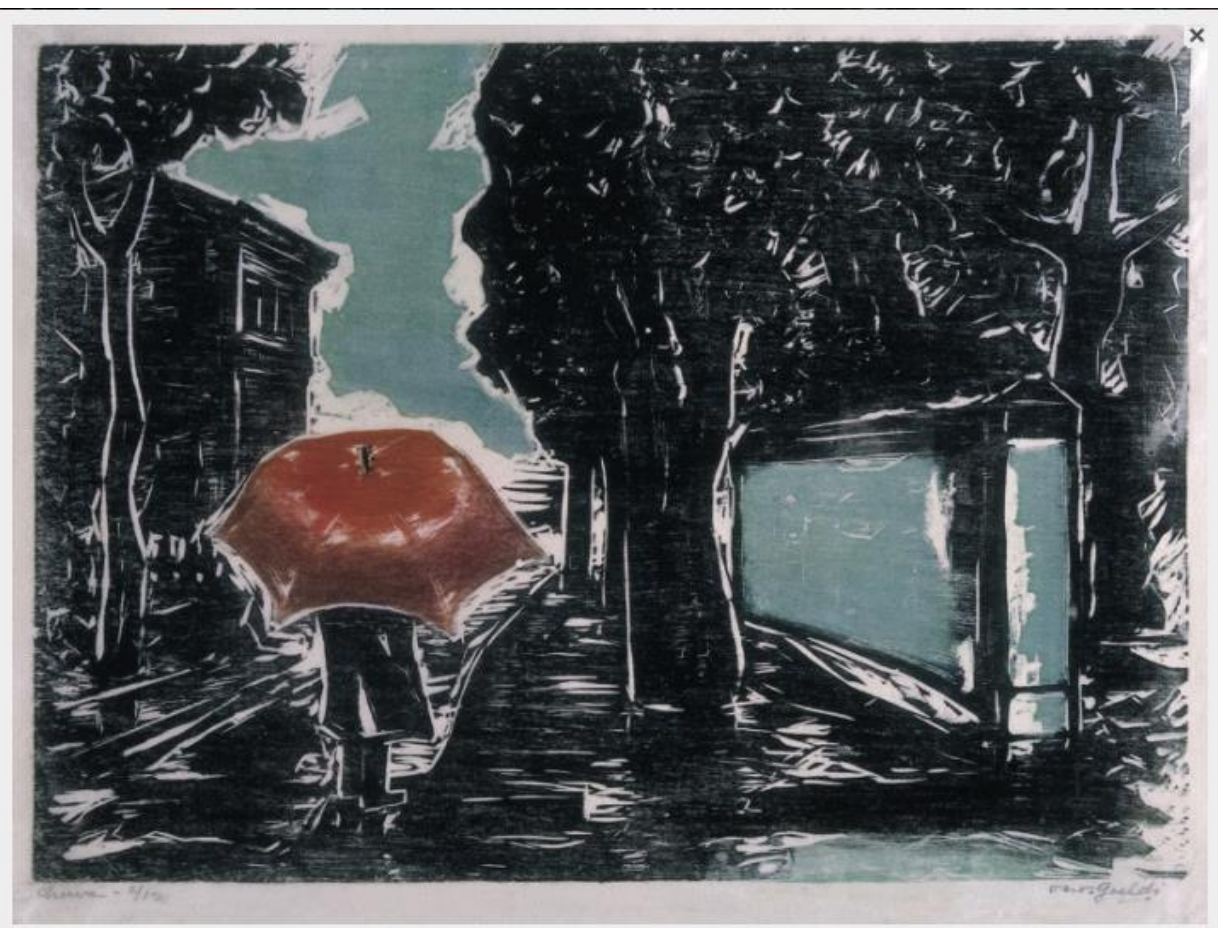

Figura 34: GOELDI, OSWALDO, Chuva. 1955. Xilogravura a cores, $22 \times 29,5 \mathrm{~cm}$.

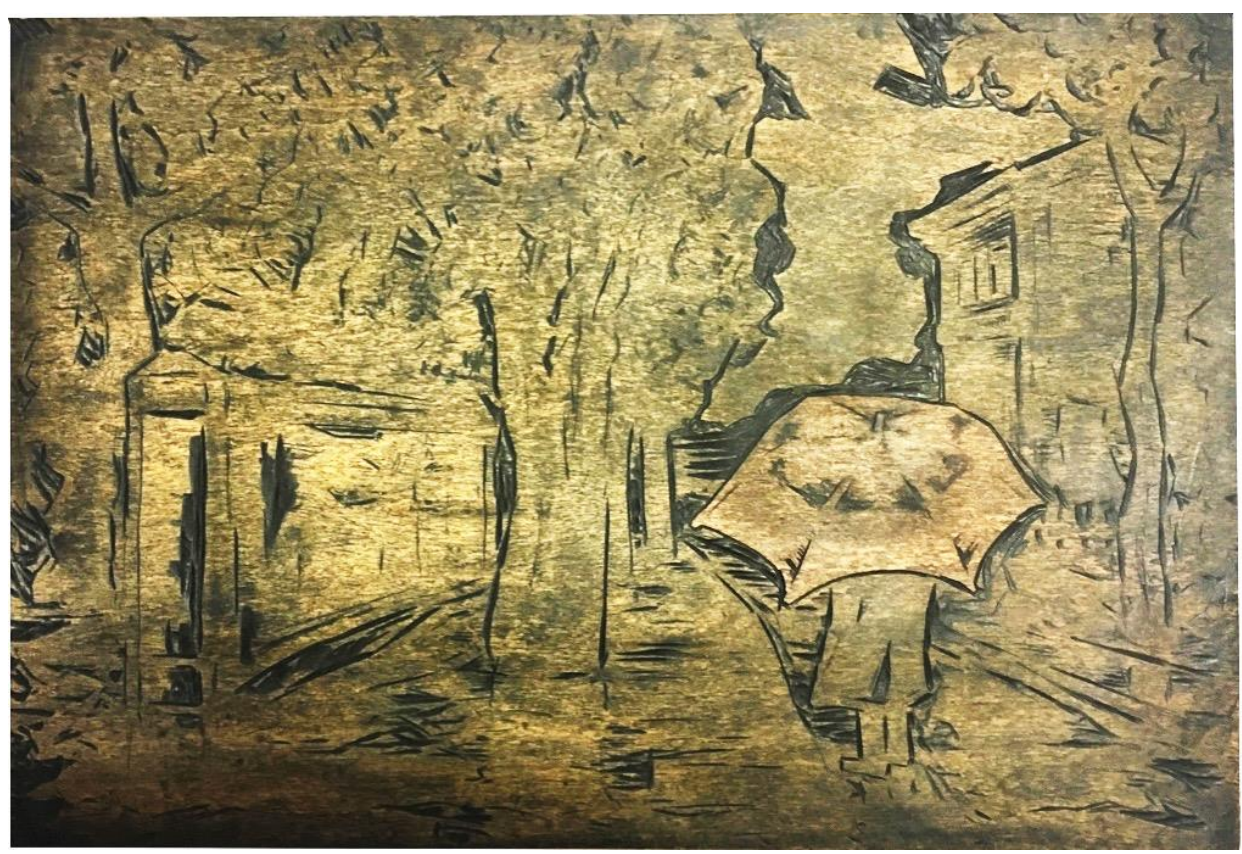

Figura 35: GOELDI, OSWALDO. Chuva, 1955.

Matriz xilográfica, 21,6 x 29,8 x $1 \mathrm{~cm}$, MNBA 


\section{3. Imensidão íntima}

"O mundo é grande mas em nós ele é profundo como o mar." Rilke $^{73}$

3.1.

\section{Casa e refúgio}

As casas goeldianas não são lugares acolhedores. Grandes casarões antigos, que abrigam mistério e sonhos, chegam a ser fantasmagóricos, sem mostrar seu interior. Imponentes mas sombrios, ocupam grande parte do espaço das cenas, desproporcionalmente maiores que os passantes. $\mathrm{Na}$ fenomenologia da imaginação, a casa representa o nosso lugar no mundo, nosso primeiro universo. Onde nos enraizamos, é o local em que emanam as imagens de valores do espaço habitado, do não-eu que protege o eu. Uma das grandes forças de integração para pensamentos, lembranças e sonhos do homem, tendo o devaneio como princípio de ligação.

Antes de ser lançado ao mundo, o homem é acolhido no berço onde a vida começa protegida e agasalhada. As lembranças desse espaço levam a imaginação ao lugar de uma infância imóvel, onde fixações de felicidade trazem o conforto da proteção do início da vida. Lugares onde se viveu a fantasia em profundidade se organizam por si mesmos em um novo sonho e, assim, as lembranças das antigas moradas revividas transformam as casas do passado em imorredouras.

Goeldi nasceu na Ladeira do Ascurra, no bairro do Cosme Velho, no Rio de Janeiro, em 1895. A família se transferiu para Belém, no Pará, logo após seu nascimento. Filho do importante botânico suíço, Emílio Goeldi, que foi contratado pelo Imperador D. Pedro II para pesquisar a flora e a fauna amazônicas e reorganizar o Museu Paraense. Permaneceram apenas seis anos em terras belenenses, tempo suficiente para que Goeldi tivesse suas faculdades perceptivas aguçadas pelo "espetáculo surpreendente da multiplicidade das formas e das cores" ${ }^{, 74}$, constituindo um pano de fundo de sua memória visual.

Voltando à Suíça, passou da infância à adolescência em uma ambiência burguesa de valorização da arte e da cultura. Lembranças nostálgicas do Brasil

\footnotetext{
${ }^{73}$ RILKE, Rainer Maria. Apud BACHELARD, Gaston. A poética do espaço. P.189.

${ }^{74}$ REIS JÚNIOR, José dos. Goeldi. P.31.
} 
eram mantidas por Emílio, que muito se afeiçoou ao Brasil, de onde todos sentiam a ausência "do sol, da paisagem e dos costumes tropicais"75. Os anos em Berna podem ter contribuído para o fortalecimento de sua índole romântica, e, certamente, a formação europeia possibilitou o desenvolvimento de habilidades fundamentais para a construção de sua poética, como a disciplina e a seriedade com que se debruçou sobre o ofício. Entretanto, à exceção dos primeiros desenhos, não se percebe influência do cenário suíço na construção de sua temática.

A metafísica da consciência acontece a partir do momento em que o homem é lançado no mundo sem o acolhimento que está associado primitivamente ao ser. Para ser completa, englobando consciente e inconsciente, deixa no interior a garantia de seus valores. Quando se sonha com a casa natal, na extrema profundeza do devaneio, volta-se a esse aquecimento inicial, à maternidade da casa.

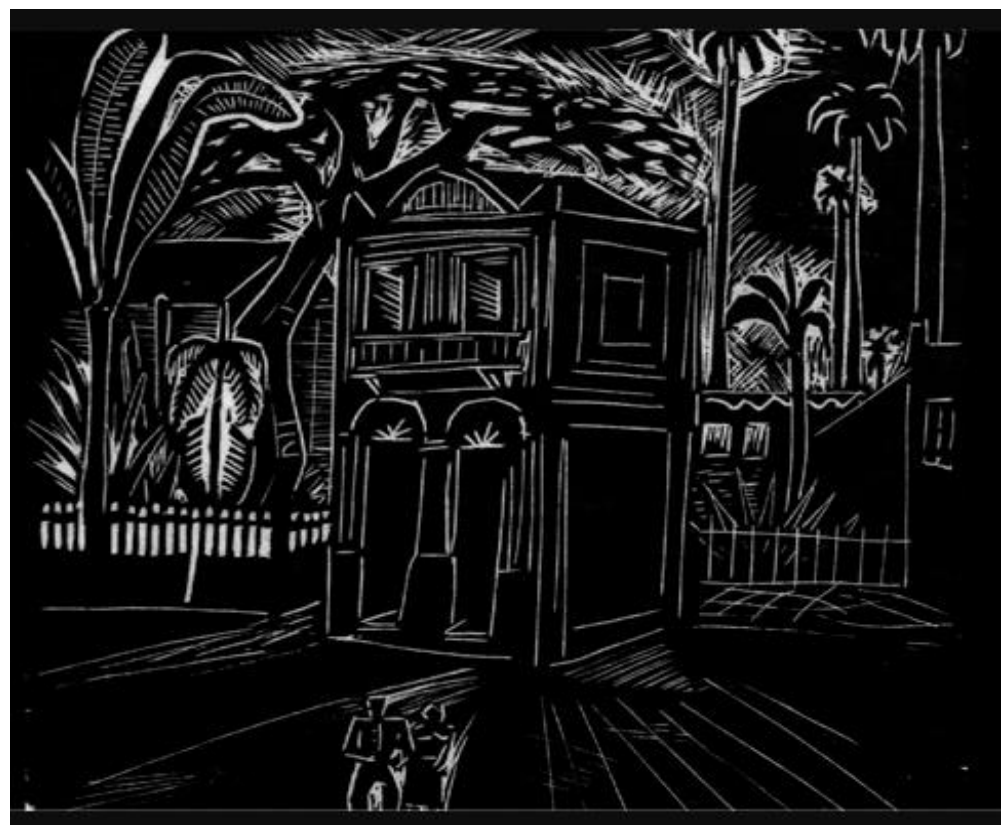

Figura 36: GOELDI, OSWALDO. Jardim Tropical, circa 1930. Xilogravura, $14,5 \times 14,7 \mathrm{~cm}$.

\footnotetext{
${ }^{75}$ REIS JÚNIOR, José dos. Goeldi. P.31.
} 
Há uma profundidade intrínseca ao negro que tenta nos levar ao interior denso, escuro e misterioso das casas goeldianas, contudo permanecemos nos limites de portas e janelas. Nos meandros do devaneio, o caráter imaginativo da representação de uma morada pode ocultar a sua intimidade, oniricamente a casa deve preservar "sua penumbra". O que Goeldi nos diz sobre sua residência de infância é justamente o necessário para se posicionar no limiar de uma divagação que repousa no passado: a particularidade do seu interior não nos é dada a ver. Como em Noturno (Fig. 37), de 1940, onde os casarões estão protegidos por uma grande muralha em torno da praça assegurando os limites intransponíveis do seu recôndito. Por ser a representação da casa um estado da alma, mesmo que reproduzida em seu aspecto exterior, sempre falará de intimidade. Bachelard trouxe para seu estudo uma pesquisa com crianças polonesas e judias que sofreram com a ocupação alemã na Segunda Grande Guerra. Com interpretações de psicólogos, em texto de 1957, o estudo identificou em desenhos que a marca das angústias do grupo se expressava mais nas imagens das casas do que em outras partes dos desenhos. A análise detectou grande rigidez e imobilidade nas casas que se apresentavam frias e fechadas.

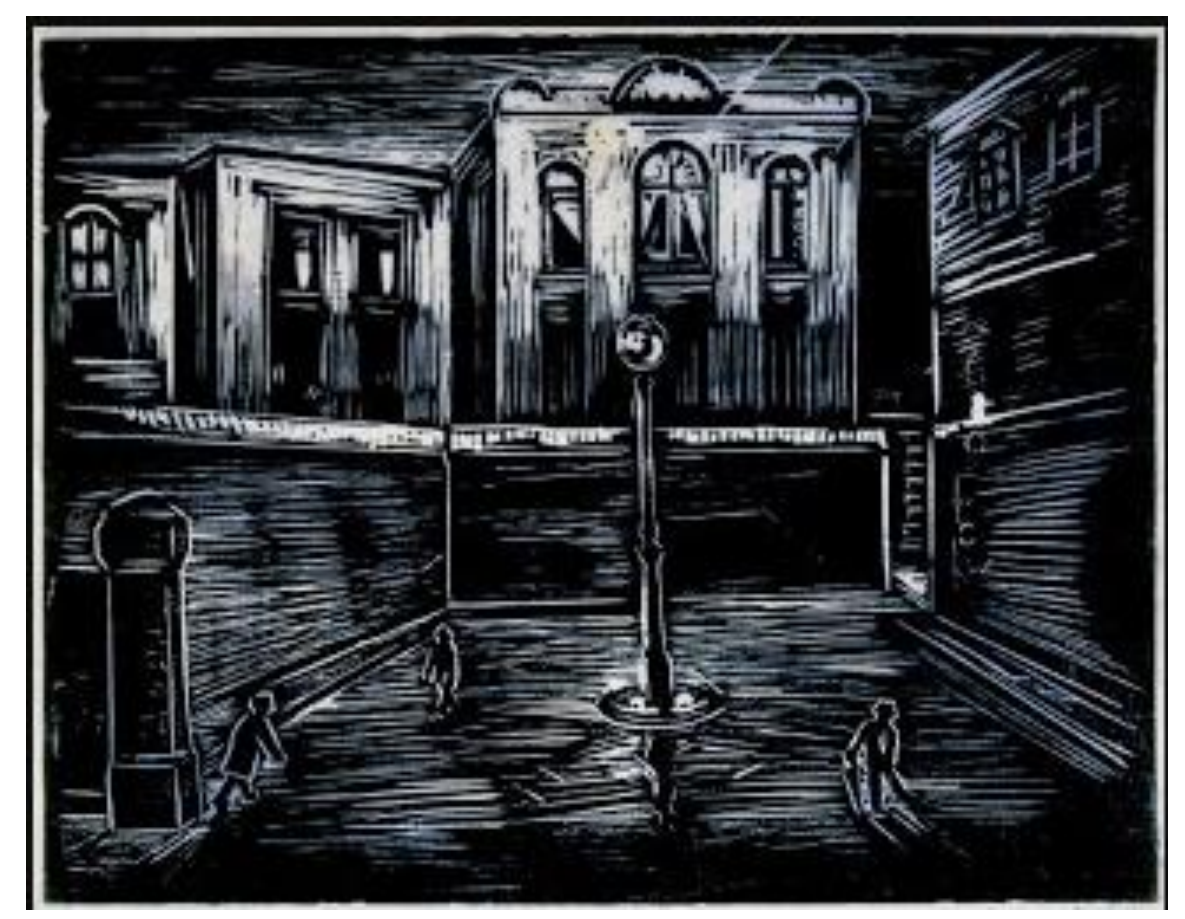

Figura 37: GOELDI, OSWALDO. Noturno, 1950.

Xilogravura, 20,8 x 26, $9 \mathrm{~cm}$. 
Sendo a casa um objeto geométrico, visível e tangível, há a tendência em analisa-la racionalmente. Concebida predominantemente em linhas retas, de sólidos bem construídos, de estrutura simétrica bem encaixada, poderia resistir a metáforas relativas à alma humana. A racionalidade abre campo para o onírico quando a habitação passa a ser vista como um espaço de conforto e interioridade. Contudo, não perde toda a objetividade, já que a relação realidade-sonho nunca é definitivamente resolvida. As moradas antigas podem até ser registradas como uma representação do real, num gesto objetivo como um documento rígido e estável que marca uma biografia. Em uma simples apreciação da expressão adequada, a reprodução realista logo prolonga-se em contemplação e o sonho volta a habitar o desenho.

A casa significa um conjunto de imagens que traz ao ser razões ou ilusões de estabilidade. Ao reimaginar a realidade deste lugar, o homem distingue todas essas imagens e revela uma alma da casa que pode ser imaginada numa consciência de verticalidade na polaridade entre porão e sótão. O sótão remete à racionalidade do abrigo da chuva ou do sol, revelando imediatamente sua razão de existir. Os pensamentos ligados ao telhado são claros. Quanto ao porão, que revela a forte estrutura do vigamento, a racionalização pode acontecer no que diz respeito à utilidade, mas, em princípio, é a parte que reflete a obscuridade da casa, portanto, reflete o âmbito inconsciente. $\mathrm{O}$ sonho com a potência subterrânea do alicerce leva à irracionalidade das profundezas psíquicas do ser. C. G. Jung utiliza a dupla imagem do porão e do sótão para analisar os temores que habitam a casa: "a consciência comporta-se então como um homem que, ouvindo um ruído suspeito no porão, precipita-se para o sótão para constatar que lá não há ladrões e que, por conseguinte, o ruído era pura imaginação. Na realidade, esse homem prudente não ousou aventurar-se no porão" ${ }^{, 76}$. Em vez de enfrentar o inconsciente do porão, o homem precavido de Jung procura sua coragem no sótão, ali onde os medos racionalizam-se com mais facilidade, onde o dia dissipa os temores noturnos. No porão, a racionalização pode ser lenta, menos clara e nunca definitiva, é o lugar onde há trevas dia e noite.

\footnotetext{
${ }^{76}$ JUNG, C.G. Apud BACHELARD, Gaston. A poética do espaço. P.37
} 


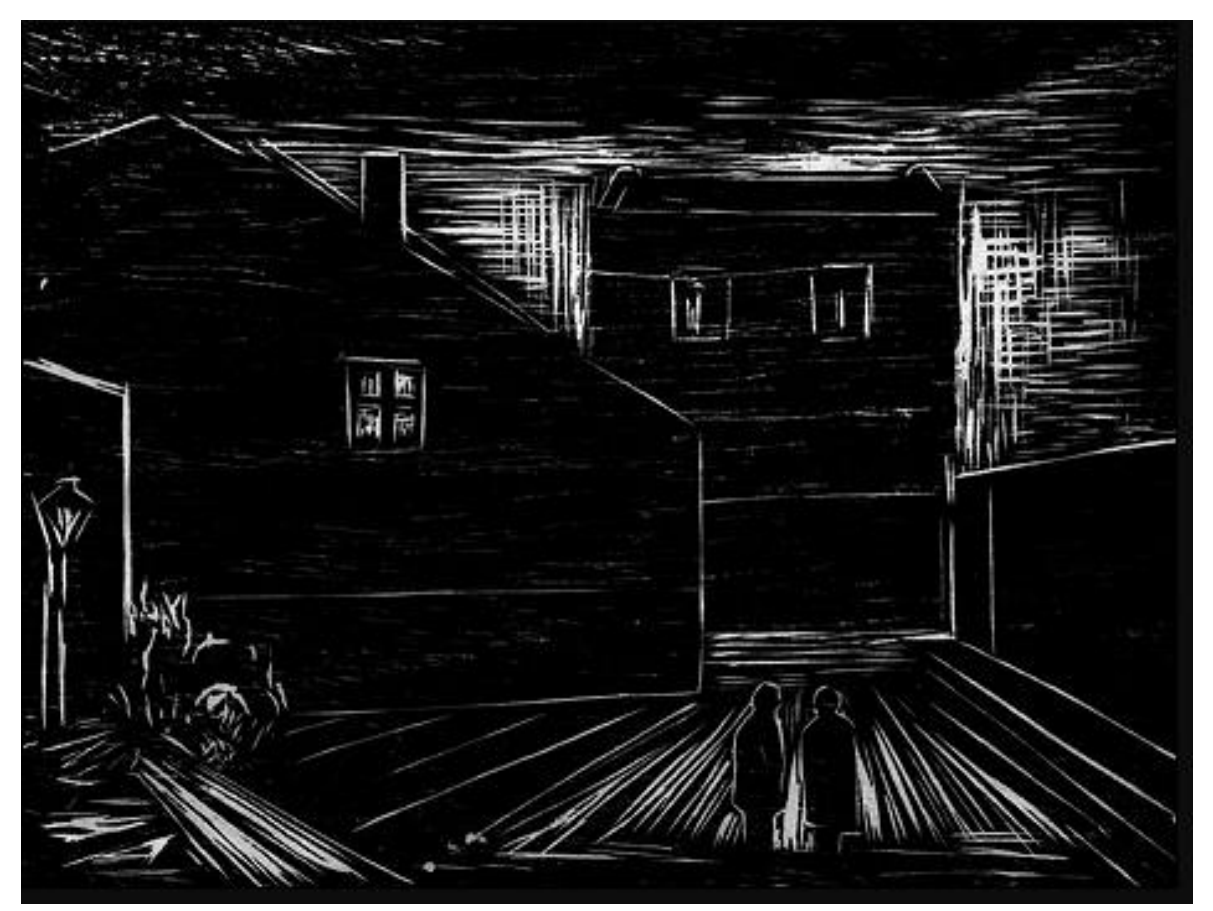

Figura 38: GOELDI, OSWALDO. Silêncio, 1957. Xilogravura, $18,7 \times 24 \mathrm{~cm}$.

As casas goeldianas têm alma, são personagens autênticas, entidades vivas em gravuras e desenhos. Recebem feições ameaçadoras por meio de janelas e portas impenetráveis que amedrontam tanto quanto as tempestades. A polaridade destas residências está no dentro e fora. O ser prudente jungiano não ousa penetrar as casas porque o fantástico transformou-as em fantasmas. Na dialética de interior e exterior, a porta adquire suma importância simbólica para o estudo das moradas. Esquematiza as divagações quando está bem fechada, com a tentação de abrir o ser em seu âmago, e quando está aberta, com o desejo de conquistar os reticentes. Proporciona ainda muitas outras imagens como hesitação, segurança, acolhida ou respeito. Em Silêncio (Fig. 38), não há portas nos grandes casarios. A possibilidade de se imaginar interior e exterior é praticamente eliminada. As construções fortes, graves e inflexíveis ocupam a verticalidade do espaço ainda marcado por um muro alto e severo, ambiência de opressão que remete à carência e solidão. As imagens mudas que rejeitam a proximidade geram desconforto, não havendo possibilidade de uma convivência tranquila, incomodam mais pela impossibilidade de nelas nos escorarmos.

A volta de Goeldi ao Brasil foi marcada por frustrações. Encontrou um ambiente hostil e impermeável a suas ideias, no meio artístico como nas relações 
familiares. Em 1921, realiza a primeira exposição no Liceu de Artes e Ofícios do Rio de Janeiro. O público, desinformado das questões contemporâneas da arte, não compreendeu a abordagem expressiva pouco realista. Os raros críticos de arte olharam sua obra com desconfiança. A experiência foi desastrosa para o artista e o isolamento viria como consequência. No entanto, alguns intelectuais como o crítico literário Otto Maria Carpeaux, e escritores como Álvaro Moreyra, Olegário Mariano, Rachel de Queiroz, Aníbal Machado e Manuel Bandeira se interessaram por sua obra pela intensa força poética.

Mas a falta de êxito na exposição entre os artistas plásticos levou-o à incerteza sobre o caminho a seguir. "Nesse pleno abandono e se deixando levar pela ânsia de artista, torna-se boêmio"77. Um conselho de família decide manda-lo de volta à Europa, deixando-o atônito. Em 1922, embarca na terceira classe do vapor Valdívia mas não chega ao destino, sendo trazido de volta ao Rio pela solidariedade de amigos, como a poetiza francesa Béatrix Reynal, que rapidamente se movimentou a levantar recursos. Não mais se relacionaria com sua família, optando pela solidão transfigurada nos "claros-escuros das visões

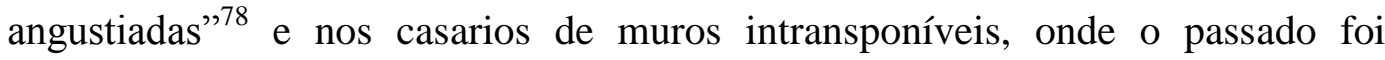
guardado, residindo com as amarguras.

Com frequência a psicanálise situa as paixões no mundo. Para a teoria bachelardiana, elas se desenvolvem na solidão. No estado de insulamento é que o ser passional organiza suas explosões ou ações. Os espaços das solitudes passadas são indestrutíveis no ser, que não deseja apaga-los por saber instintivamente que constituem sua essência. E é nesse âmago que a casa natal está inserida. As sucessivas moradas em que se habita ao longo da vida podem banalizar gestos, mas ao se voltar à antiga, percebe-se que os mais delicados, iniciais, subitamente estão presentes, vivos e perfeitos. Todas as outras passam a ser apenas variações de um tema fundamental.

Goeldi vivia uma profunda solitude criadora. Os ambientes em que escolhia para viver influenciavam diretamente seu trabalho. Morou durante um período em Niterói, cruzando a Baía de Guanabara todos os dias, época em que descobre a

\footnotetext{
${ }^{77}$ REIS JÚNIOR, José Maria dos. Goeldi. P. 15

${ }^{78}$ Idem, ibidem.
} 
xilogravura no ateliê do artista Ricardo Bampi. Mais tarde, mudou-se para Ipanema, onde morava em um humilde sobrado perto dos amigos Reis Jr. e Béatrix Reynal. Da sua mesa de trabalho, avistava a Lagoa Rodrigo de Freitas, do Corcovado ao Morro Dois Irmãos. Ainda havia areais e cajueiros, local silencioso principalmente à noite, cenário insólito, clareado pelo luar ou por tempestades que inspiravam o artista em suas narrativas gráficas. Goeldi transpunha para a linguagem plástica os reflexos produzidos pela imagem real dos seus abrigos.

Preferia o ambiente ermo para morar e trabalhar, um refúgio onde pudesse viver o mundo romântico e sua intensa vida interior. Anos depois, vai morar na Rua Almirante Guilhem, no bairro do Leblon, em um modesto apartamento-ateliê de onde nunca mais sairia. A busca pela solidão do recanto singular não o impelia ao convívio em sociedade. Nesse Leblon antigo, convivia com pescadores, humildes operários e artesãos em comunhão com a natureza. Com um misto de lirismo, ironia e dramaticidade, perseguia o aperfeiçoamento de sua poética para que expressasse com a maior fidelidade possível suas vibrações íntimas.

A cabana do eremita é a representação da solidão centralizada. A cabana tem uma intensidade de pobreza, um despojamento que dá acesso ao absoluto do refúgio. Ficamos hipnotizados tanto pela solidão quanto pela casa vazia. A ideia da cabana, em sua forma mais simplificada, condensa a intimidade do refúgio. E é preciso chegar à primitividade do refúgio para reabrir o campo das imagens que foram os centros de fixação das lembranças. Os retiros criadores escolhidos por Goeldi denotam sua paixão pela natureza e pelo homem comum, remetem à Belém e a sua infância numa Amazônia de mistérios, bichos, gente humilde, tempestades com que tanto se identificou ao longo do caminho artístico. 


\section{2.}

\section{Infância e natureza}

"É sempre desse modo, como um fogo esquecido, que a infância pode ressurgir em nós ${ }^{79,}$.

Gaston Bachelard

Em seu discurso filosófico sobre os devaneios, Bachelard propõe uma outra abordagem ao analisar as imagens da infância. A "poético-análise" nos ajudaria a reconstruir em nós mesmos o ser das solidões libertadoras, devolvendo ao homem todos os privilégios da imaginação, assim "deixemos à psicanálise o cuidado de curar as infâncias maltratadas." As lembranças guardadas dos primeiros anos de vida são manifestações da criança permanente, uma continuidade dos sonhos em cenas da solidão. Sendo a memória um campo de ruínas psicológicas, toda a meninice é reimaginada dando a possibilidade de reencontrá-la na própria vida de nossas divagações. Segundo este pensamento, há a permanência de um núcleo de infância na alma humana, imóvel mas sempre viva, disfarçada em história quando contada, que só viria a ser real nos instantes de sua manifestação poética.

Quando nos reencontramos com o primitivo do que se imagina, mais do que em sua realidade, revivemos suas potencialidades. Sonhamos tudo o que poderia ter sido, no limite da história e da lenda. Se quando sonhava sozinha, a criança conhecia uma existência sem limites, a fantasia não é somente fuga, ela também ajuda a alçar voos. $\mathrm{O}$ mundo das divagações da infância é bem maior que o oferecido pelos sonhos do presente. Psicologicamente falando, é no devaneio que somos seres realmente livres. Em Goeldi, a liberdade das fantasias infantis foi se mostrando gradativamente e com mais força no longo processo de experimentação cromática. Apesar do resultado aquém do esperado, as ilustrações para o livro Cobra Norato (Figs. 23 e 24) trouxeram à Goeldi a materialidade de imagens da memória de criança, levando-o a inaugurar uma exposição em Belém apenas sete

\footnotetext{
${ }^{79}$ BACHELARD, Gaston. A poética do devaneio. P.98.
} 
meses depois ${ }^{80}$. Reis Jr. ressalta este momento em que o artista passa a dialogar com a imensidade primitiva das lembranças:

“A peregrinação pelo seu mundo de infância, cujas imagens perduravam vividas através do tempo, foi de grande importância para o artista: fê-lo compreender a razão recôndita da permanência daquelas imagens - elas estavam integradas no seu ser, também trabalhado pelas mesmas forças telúricas criadoras daquele mundo. Estabeleceu-lhe a origem da sua linguagem plástica, deu-lhe absoluta certeza do quanto era organicamente sua. ${ }^{81,}$

Na década de 1950, quando relata a Kubin ter sido "uma luta árdua chegar ao colorido sem perder o sentido gráfico ${ }^{82 \%}$, referia-se tanto às experimentações no processo técnico da policromia chegando às múltiplas entintagens em uma única matriz, bem como à batalha de harmonização entre criação, cor, técnica e imensidão de registros visuais que guardava nas lembranças. Como definiu Goeldi: “oscilações de sentimentos escondidas que, através de meios ainda desconhecidos, se revelam ${ }^{83}$ ", formando uma tríplice ligação imaginação, memória e poética. Os meios técnicos que levavam à cor perpassavam pelo onirismo solitário da infância e tornavam o processo de experimentação ainda mais difícil, já que nesta primitividade psíquica, imaginação e memória surgem como um complexo indissolúvel.

A história da infância não consegue ser datada psiquicamente. A noção de época é acrescida às lembranças por outras pessoas a posteriori, de lugares diferentes e de um tempo diverso do vivenciado. Narrativas que são pertencentes ao período em que são contadas. Goeldi provavelmente consolidou estas lembranças pretéritas na Suíça, contadas por seus pais em uma conexão direta com a nostalgia familiar, constituindo já como valor de imagem a ideia de expatriação, que mais tarde definiria parte da essência de sua poética.

Quando o menino atinge a idade da razão e "perde" seu direito absoluto de imaginar o mundo, os adultos lhe propõem a objetividade. Torna-se, assim, psicologicamente, um homem prematuro, em estado de infância recalcada.

\footnotetext{
${ }^{80}$ O livro Cobra Norato foi finalizado em agosto de 1937 e a exposição de Belém aconteceu em março de 1938.

${ }^{81}$ REIS JÚNIOR, José Maria dos. Goeldi. P. 31

${ }^{82}$ Carta de Goeldi a Kubin, 15/12/1950. In: RIBEIRO, Noemi. Oswaldo Goeldi: um autorretrato. P. 177.

${ }^{83}$ Carta de Goeldi a Kubin, 10/04/1952. In: RIBEIRO, Noemi. Op.cit. P. 178.
} 
Apenas com o amadurecimento da existência que se descobre, em profundidade, as solidões infantis e adolescentes. Quando a última parte da vida revive a primeira, conclui-se que a infância aguardou um tempo enorme para se reintegrar ao ser, como se adolescência, que subsiste em nós, erguesse barreiras à origem que espera por ser revivida. O começo da vida é o reino de si mesmo, do Selbst ou Self jungiano ${ }^{84}$, enquanto que "a integração do $\mathrm{Si}$, considerada em seu sentido profundo, é uma questão da segunda metade da vida ${ }^{85}$ ".

O ser do devaneio atravessa sem envelhecer todas as idades do homem, da infância à velhice. No amadurecimento, experimenta uma espécie de recrudescimento das lembranças quando tenta reviver as divagações da infância. Sobre um dos últimos trabalhos de ilustração de Goeldi, para o livro Poranduba Amazonense, tendo acompanhado seu processo criativo, Reis Jr. revelou que, durante o desenvolvimento das xilogravuras, o artista voltou intensamente às reminiscências da infância que marcaram sua sensibilidade por toda a vida. Extraindo da temática lendária formas igualmente ricas esteticamente, aprimorando o processo técnico que empregou em Sol Vermelho (Fig. 32), conseguiu imprimir duas xilogravuras para este livro antes de sua morte, deixando a obra inacabada, como se houvesse uma reconciliação com as lembranças presas nos limites interiores dos casarios sombrios.

A criança sonhadora vive sozinha no mundo do seu devaneio, com uma solidão menos social do que o adulto. Este é um estado de divagação natural de solitude que não pode ser confundido com timidez ou qualquer outra questão de personalidade que cause isolamento da sociedade. Em seus momentos de insulamento feliz, o menino sonhador conhece o devaneio cósmico, que é aquele que nos une à realidade do mundo. O lugar das lembranças dessa solidão cósmica é onde encontramos o núcleo de infância que permanece no centro da psiquê

\footnotetext{
${ }^{84} \mathrm{O}$ si mesmo é um dos três principais arquétipos jungianos, juntamente com o animus (imagem do masculino) e o anima (imagem do feminino). Os arquétipos constituem o inconsciente coletivo, base da psique, estrutura imutável, espécie de patrimônio simbólico de toda a humanidade. Essa representação da psique é complementada por tipos psicológicos e por um processo de individuação que conduz o ser humano à unidade de sua personalidade. A criança emerge do inconsciente coletivo para ir até a individuação, assumindo o animus ou o anima. RODINESCO, PLON, Michel; ROUDINESCO, Elisabeth. Dicionário da Psicanálise. Rio de Janeiro: Zahar, 1998.

${ }^{85}$ JUNG, C.G. Die Psychologie der Uebertragung. Apud BACHELARD, Gaston. A poética do devaneio. P. 102.
} 
humana, onde o ser interliga real e imaginário, vivendo com toda a inventividade as cenas da realidade.

Uma cosmicidade da infância de Goeldi residiu em seu ser, reaparecendo nos devaneios solitários de artista. Parece ter devolvido vida a uma vivência que não havia acontecido em sua totalidade, que foi apenas imaginada na exuberância da natureza paraense, deslocada com a mudança drástica de panorama visual com a ida para a Europa, mas que ficou impressa nas percepções de criança. A imaginação dos primórdios do ser vive em suas próprias fábulas e não nas que são contadas a ela. Estas fábulas não divertem, encantam. Para redescobrir a linguagem das fábulas, é necessário substituir a percepção pela admiração e passar a admirar a lembrança. Passa a existir em nosso íntimo, então, não uma memória de história, mas de imaginação cósmica. Enfocando a lembrança de forma mais ampla, Baudelaire define:

\begin{abstract}
"A verdadeira memória, considerada do ponto de vista filosófico, não consiste, acho eu, senão numa imaginação muito viva, fácil de emocionar-se e, por consequência, suscetível de evocar em apoio de cada sensação as cenas do passado apresentando-as como encantamento da vida ${ }^{86 "}$.
\end{abstract}

${ }^{86}$ BAUDELAIRE, Charles. Curiosités esthétiques. P.160 


\section{3. \\ Águas}

"Homem liberto, hás de estar sempre aos pés do mar! O mar é teu espelho; a tua alma aprecias

No infinito ir e vir de suas ondas frias, E nem teu ser é menos amargo ao se abismar" ${ }^{87}$

Charles Baudelaire

Em sua vastidão simbólica de sonhos, mistérios, vida e morte, a força imagética da água foi presença constante na obra de Goeldi. No entanto, apenas criar conexões do mundo interior goeldiano com o mar, o rio, a chuva ou a poça seria quase uma redundância alegórica na análise de sua obra. O que pretendemos aqui é estreitar o diálogo entre a força poética do artista e sua predileção por imagens fluidas impregnadas de signos.

O cenário insólito de mares quase sempre bravios se adentra por noites profundas de lua cheia ou tardes envoltas em nuvens que profetizam chuvas torrenciais e vento, muito vento. Metáforas de fúria e raiva no devaneio solitário do oceano. Pescadores de capas e chapéu na praia, arrastando redes, em barcas, dentro de barracas ou limpando peixes no mercado. Mesas, facas, ganchos, cestos e caixas de gelo espalhadas pelas cenas. $\mathrm{O}$ ar úmido prevalecendo em névoas de madrugadas frias, chuvas e poças, espelhos d'água. Nessa ambiência da atividade pesqueira, o relato captado in loco sobre a vida humilde de protagonistas anônimos que eximem o artista de ter "que lidar com a psicologia particular de cada um" ${ }^{\prime 88}$. O mar favorece a meditação que proporciona uma contemplação que decifra a intimidade do mundo, "à aflição de uma alma corresponde a desgraça de um oceano ${ }^{89}$ ".

As imagens da água participam formalmente como ornamento da paisagem e não como substância. Contudo, existe toda uma representação onírica sob a superficialidade do adorno que oculta a tonalidade profunda do devaneio criador. Uma imaginação material da água que a princípio remete à dispersão e volatilidade pode ser densa e pesada quando analisada sob a ótica do devaneio

\footnotetext{
${ }^{87}$ BAUDELAIRE, Charles. O homem e o mar. Flores do Mal. P.145.

${ }^{88}$ SIQUEIRA, Vera Beatriz. Cálculo da Expressão. P.21.

${ }^{89}$ BACHELARD, Gaston. A água e os sonhos. P.180.
} 
materializante - aquele que sonha com a matéria - que está além da forma. A água passa a enviar a mensagem de seus reflexos por sua massa e não mais por sua superfície, já que "só a massa pode receber a carga das impressões e dos sentimentos múltiplos"90.

O espelho d'água nas gravuras tanto pode refletir o vai e vem das ondas, das chuvas ou das luzes do céu na reincidência rítmica do movimento que gera tensão, como pode representar um olhar sobre a rotina condicionante do trabalho dos pescadores em sua árdua luta cotidiana. $\mathrm{O}$ espelho que revela os passos, o ir e vir da insistência e da repetição. Torna-se, assim, um signo do processo artesanal do ofício da xilogravura, que assim como a atividade dos pescadores, tinha para Goeldi um modus operandi quase ritualístico. O gestual sistemático nos procedimentos de escolha e preparação da madeira, desenho, entalhe, impressão, trabalhando laboriosamente para exprimir o instante único captado na cena ordinária. A experiência desse flagrante da realidade cotidiana é o que aproxima as gravuras goeldianas da linguagem fotográfica ${ }^{91}$, apesar da falta do naturalismo e da perspectivação próprias do registro da câmera.

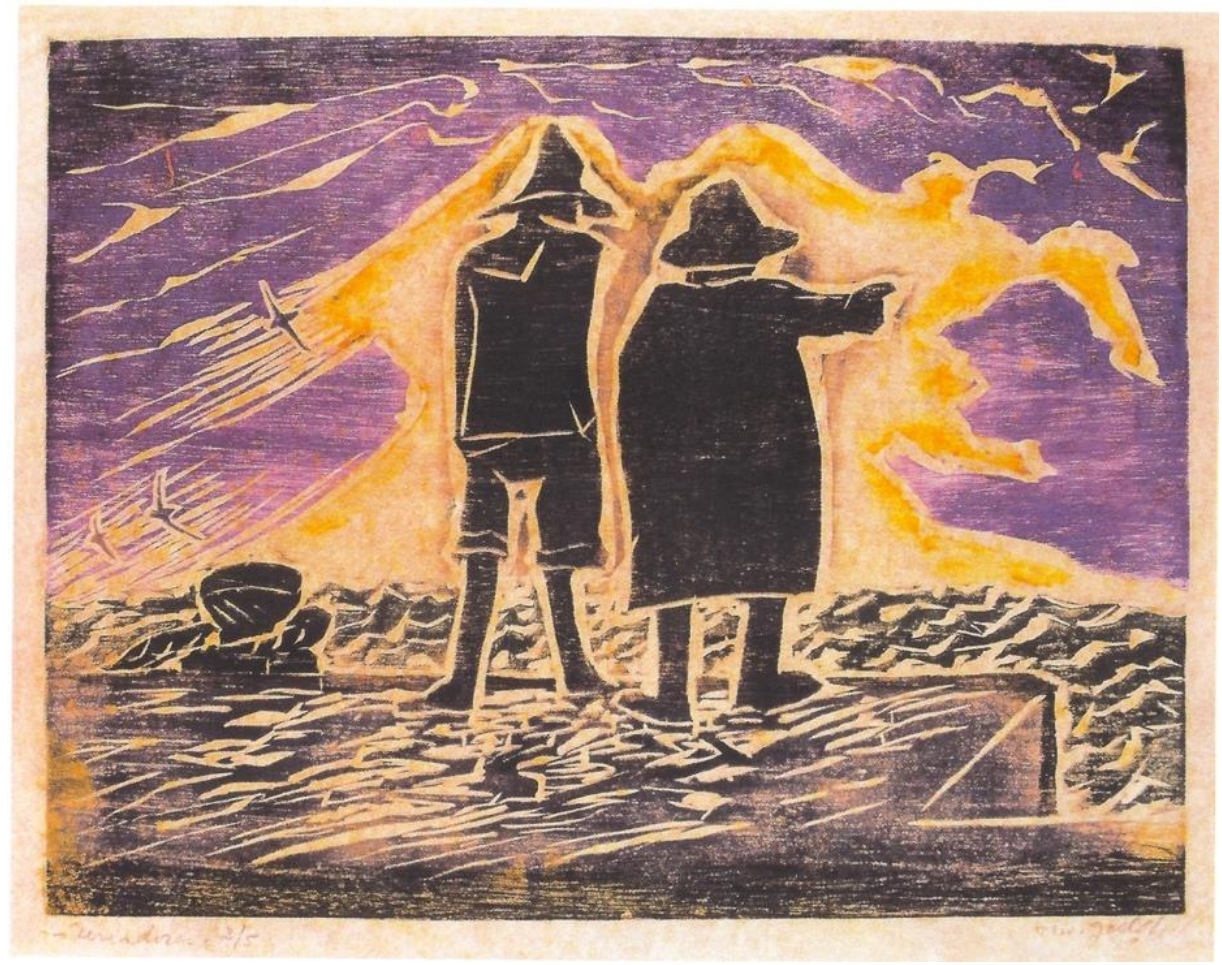

Figura 39: GOELDI, OSWALDO. Pescadores, 1955.

Xilogravura a cores, $21 \times 27 \mathrm{~cm}$.

\footnotetext{
${ }^{90}$ BACHELARD, Gaston. A água e os sonhos. P.53.

${ }^{91}$ SIQUEIRA, Vera Beatriz. Cálculo da Expressão. P.23.
} 
Em Pescadores (Fig. 39), a água aos pés dos homens reflete pouco de suas formas, espelha a luminosidade do céu por traços nervosos dando o tom de tensão da cena no prolongamento do mar revolto. Toda a ação das águas e das nuvens é interrompida pela posição estática dos pescadores ao centro. Paramos os olhos neles, na mão que aponta para o firmamento, longínquo e inacessível aos nossos olhos, ostentando o que não podemos ver. "Nos nossos olhos é a água que sonha" ${ }^{\text {92 }}$. Na natureza, o olho da terra é a água, portanto, é ela que vê e que sonha, tudo se compõe em torno dela, é a origem de tudo. $\mathrm{Na}$ imaginação, com todas as forças do sonho e da contemplação, a água é o olhar que vem da terra. Na gravura Pescadores (Fig. 38), os corpos vão até a margem, mas o olhar não para por ali, navega com as ondas, sonha com o horizonte, viaja com fluidez da própria imaginação. Quase podemos ouvir o barulho das ondas que parecem ressonar na imaginação do artista e nos perguntamos o que pode existir nesse mar de dúvidas, o que eles estão vendo do mundo que nós não vemos, ou que o artista não quer que vejamos.

Retratado em muitas gravuras de Goeldi, o espelho d'água, seja na areia da praia, no rio ou na poça de chuva, carrega o fardo simbólico da contemplação do Eu, do espelho narcísico. A água dá mais naturalidade e leveza à contemplação egoística do espelho de vidro, mas ainda assim remete ao olhar a si mesmo. Em Nuvens Pretas (Fig. 40), o pescador que se vê ao chão apressa-se em fugir da tempestade iminente. $\mathrm{O}$ espelho d'água colorido em verde, assim como o mar, dão um tom de lirismo à cena, de fluidez e continuidade, diminuindo o peso opressor do céu negro. Os riscos traçados no sentido das estrias da madeira determinam percursos, ora do vento, ora da água, dando o grau de intensidade da chuva.

\footnotetext{
${ }^{92}$ BACHELARD, Gaston. A água e os sonhos. P.33.
} 


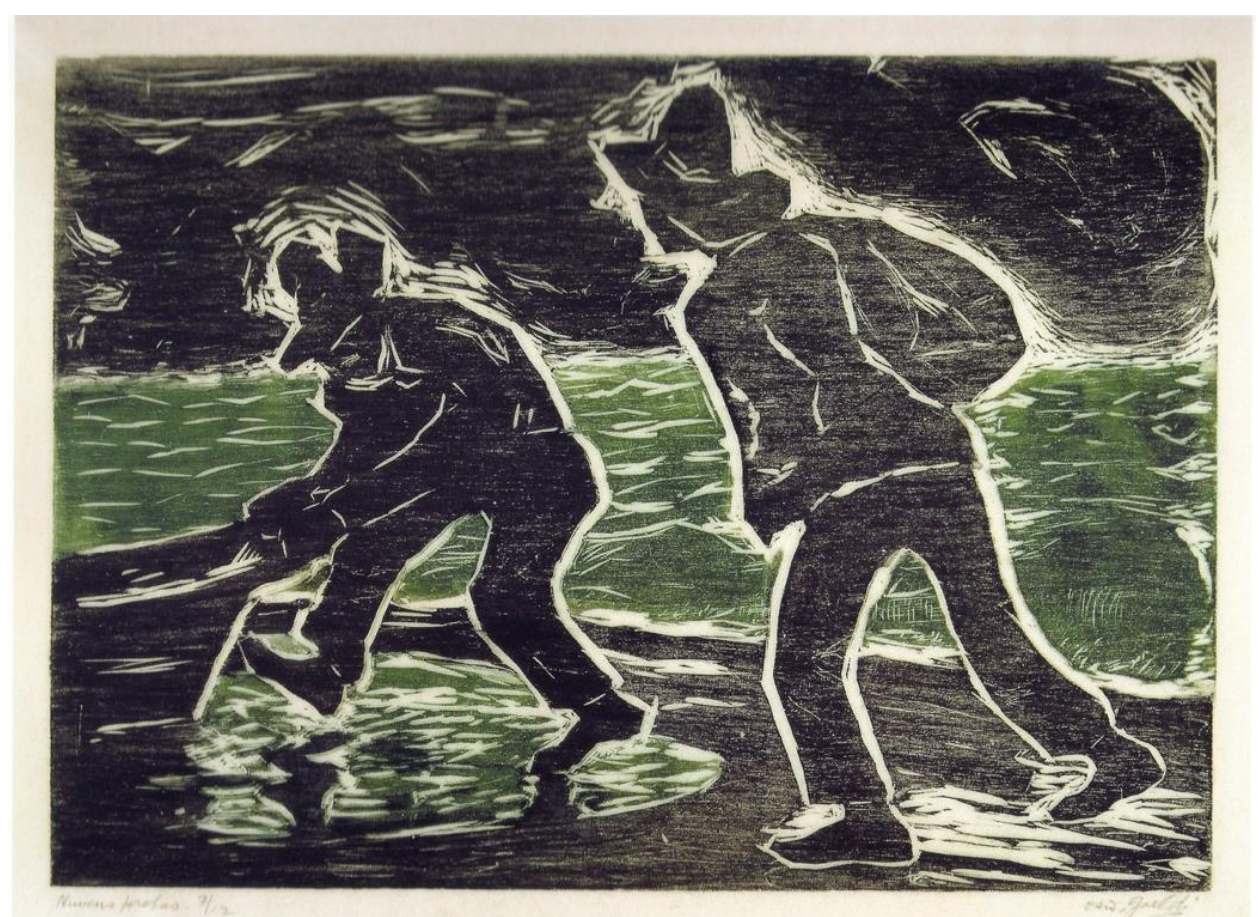

Figura 40: GOELDI, OSWALDO. Nuvens pretas, 1953. Xilogravura a cores, 22,2 x 29,8 cm.

A água é o elemento triste da natureza. O símbolo da morte jovem e bela, dos dramas da vida, como se os mares e os rios reunissem todas as lágrimas do mundo. A relação da água com a morte vem das imagens da viagem fúnebre, do que é levado para longe e se dissolve. Assim como o fogo e a terra têm sua dissolução em fumaça e pó, a água dá a impressão de se dissolver mais facilmente em si mesma, longe dos olhos. O devaneio de dispersão que a água promove nos remete ao rápido aniquilamento, o morrer totalmente: "para certas almas, a água é a matéria do desespero" $" 93$.

Em Crepúsculo (Fig. 41), em um habitat de desalento e obediência ao absoluto, a natureza contemplada e a natureza contemplativa se interagem com diferenças muito sutis. O que está sendo observado incentiva o expectador a contemplar, numa relação de dependência que se amplia entre nós, observadores, e a cena. Queremos ver o que há além da imobilidade letárgica dos pescadores, o transcendente à imagem, mas uma perfeita muralha que se forma com os corpos a nossa frente impede os olhos de mergulhar a fundo. A estrutura perspéctica, em sua bidimensionalidade, não permite que nosso olhar chegue ao horizonte iluminado, de que temos uma visão parcial. No espaço único de fuga, acima do

\footnotetext{
${ }^{93}$ BACHELARD, Gaston. A água e os sonhos. P. 95.
} 
pescador agachado, nos deparamos apenas com o negro do céu, que achata e retém o fundo. Há uma tensão van goghiana nos contrastes dos riscos de luz e contornos, quebrando o silêncio litúrgico que o momento condiz. O último pescador à direita, que parece estar posicionado de frente para nós, desestabiliza a cena com seu deslocamento, impede a transcendência dos devaneios da água, nos faz questionar o porquê da matéria. Deixando de contemplar a natureza por um instante, torna-se o elemento que dá o limite à experiência dos sonhos.

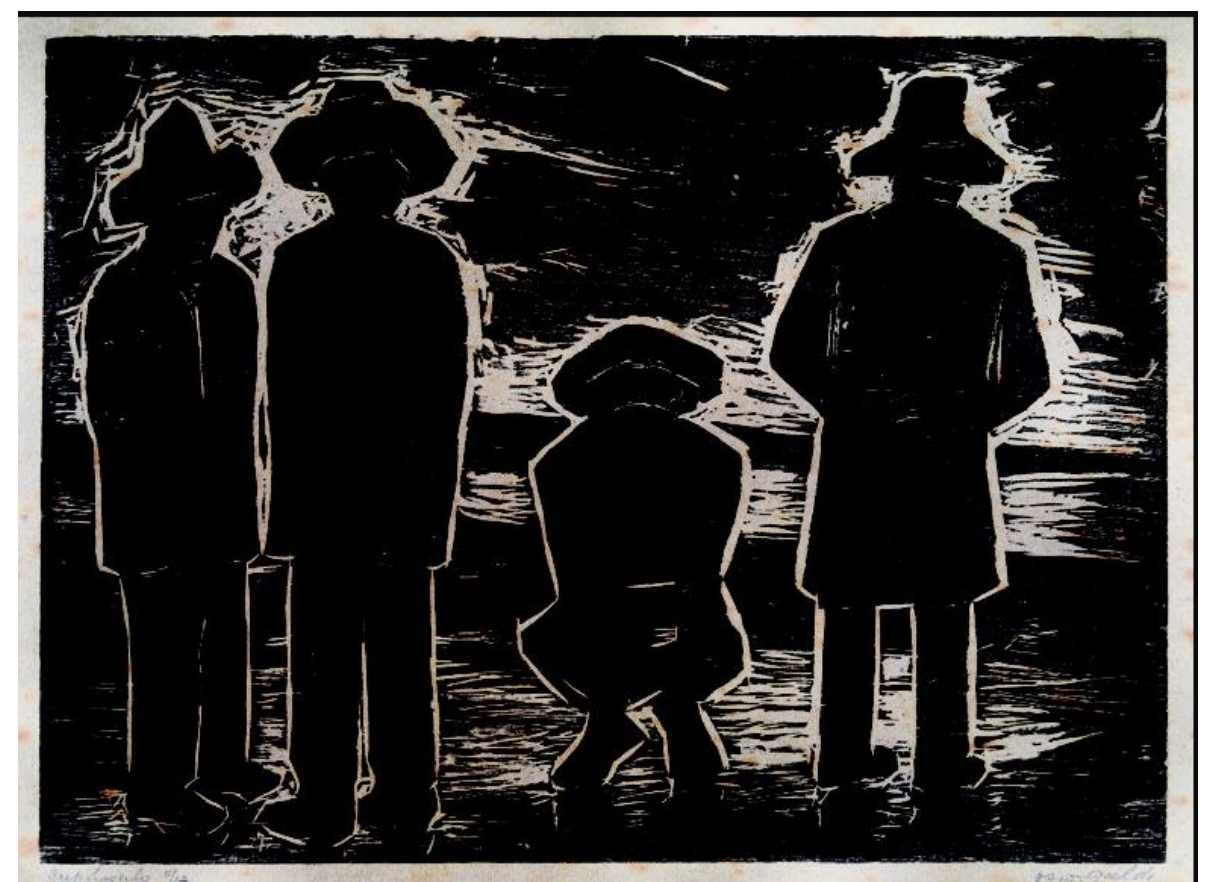

Figura 41: GOELDI, OSWALDO. Crepúsculo, 1957. Xilogravura, 22,2 x $30 \mathrm{~cm}$.

Há no signo da água uma representação de pureza, não em relação ao mérito dos rituais formais de purificação, mas como símbolo natural da matéria pura. Nas gravuras de rios e lagos, há a comunhão com a fauna nativa em uma certa candura selvagem na ideia de paraíso tropical. Um ambiente distante das máquinas e do progresso que prometiam salvar o homem, no qual Goeldi não acreditava. Preferia a simplicidade pura da natureza e dos que com ela conviviam:

"Os fenômenos da natureza me empolgam - trovoadas, ventanias, nuvens pesadas, céu e mar, sol e chuva torrencial e noites cheias de mistério, pássaros e bichos. Os dramas da alma humana me comovem, sinto-me bem com os simples e às vezes me confundo com eles"

\footnotetext{
${ }^{94}$ GOELDI, Oswaldo. Notas íntimas. Apud REIS JÚNIOR, José Maria dos. Goeldi. P.28
} 
Para a psicanálise, os traços objetivos da paisagem são insuficientes para explicar o sentimento profundo do homem em relação à natureza. O mar-realidade por si só também não exerceria tamanha fascinação nos seres humanos. Há um quê de nossas lembranças inconscientes associado ao mar azul ou à montanha verde que nos atrai além da imagem real. A natureza como um todo seria uma projeção da figura materna ampliada, eterna e lançada no infinito - a ideia de mãe-natureza caberia aqui. O primeiro princípio ativo da projeção das imagens, força propulsora da imaginação, estaria relacionado aos sentimentos primevos entre filho e mãe. Na inevitável conexão das imagens da água com a maternidade, o mar é considerado um dos maiores símbolos maternos, que remeteria à ideia de abrigo-nutrição e à infinitude do amor maternal.

Em seu texto A água e os sonhos, Bachelard analisa a obra de Edgar Alan Poe a partir dos estudos psicanalíticos de Marie Bonaparte sobre a poética do escritor americano. ${ }^{95}$ Considerando que, por várias formas, a imaginação oculta um elemento privilegiado que determina a unidade e hierarquia dos meios de expressão, o filósofo demonstra que esta química poética teria a água como substância superlativa em Poe. As imagens da água seguiam o destino da principal marca inconsciente do escritor que era o devaneio da morte, mas precisamente o que revia o falecimento materno nas principais passagens das mulheres de suas histórias. "O humano, em Poe, era a morte"96, e a água escura e pesada tinha o papel de "absorver o sofrimento" da orfandade e escoar a lembrança do passamento.

Podemos dizer que a água era, certamente, um eminente personagem no universo de signos goeldianos. Se na literatura, "não há epopeia sem uma cena de tempestade ${ }^{97}$, em Goeldi, há poucas gravuras sem a percepção de umidade, seja com sua presença propriamente visível no desenho, seja diluída na ambiência formada pelas finas estrias que compõe as cenas. Sendo a violência da água uma das principais metáforas da cólera, do ressentimento e do medo, a expressão de temor se intensifica com a combinação de imagens líquidas e noturnas. O mar

\footnotetext{
${ }^{95}$ BONAPARTE, Marie. The life and works of Edgar Allan Poe. Apud em BACHELARD, Gaston. A água e os sonhos, ensaio sobre a imaginação da matéria. P.47.

96 Idem, ibidem.

${ }^{97}$ BACHELARD, Gaston. Op.Cit. P.184.
} 
revolto e as fortes chuvas frequentes nas xilogravuras remetem a esse universo do fenômeno que não controlamos, sobre o qual conseguimos até sentir alguma proteção em um guarda-chuva ou à beira-mar, mas não ficamos livres da tensão intrínseca. A luta contra a água, com suas vitórias e derrotas na pesca, nas tempestades ou fora delas, se insere na ambivalência da alegria e da dor, presente em toda a obra do artista.

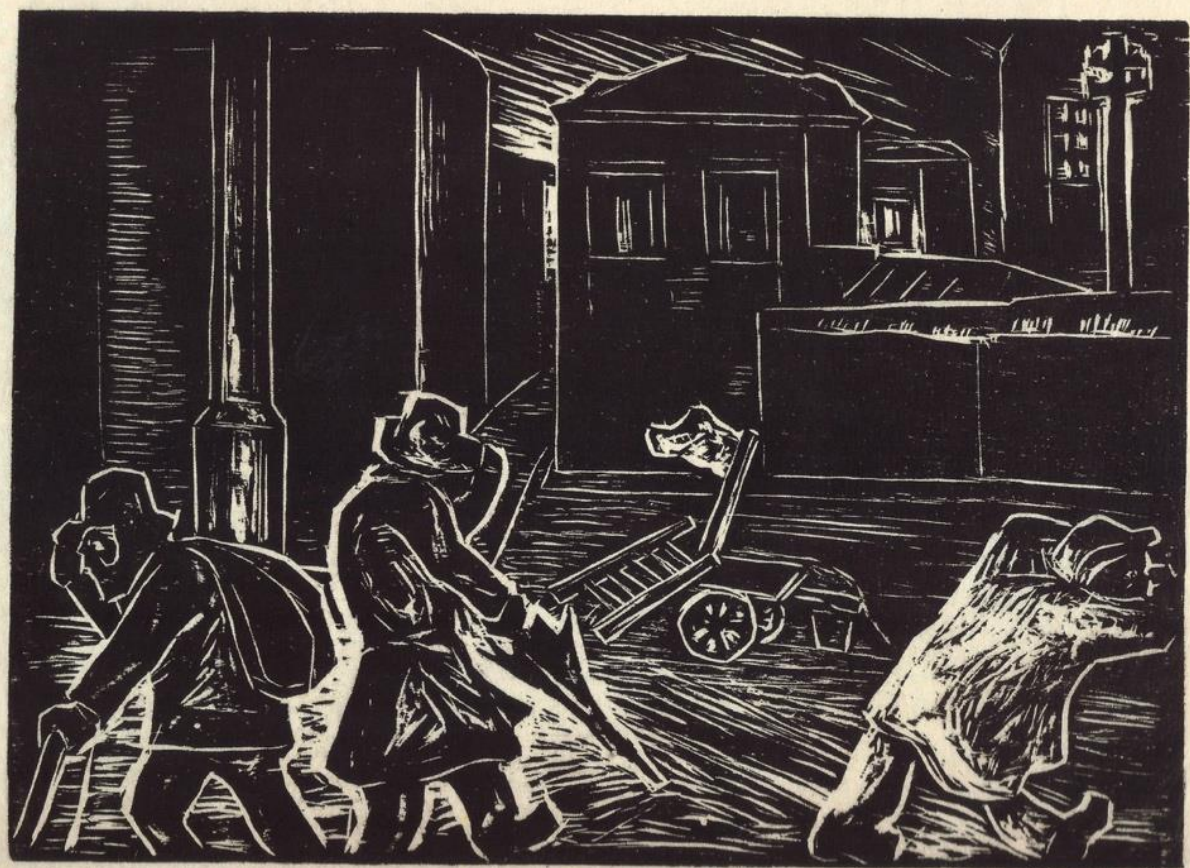

Figura 42: GOELDI, OSWALDO. (Ameaça de chuva), 1945. Xilogravura, 19,9 x 27,5 cm. 


\title{
3.4 .
}

\section{A cidade e a morte}

"Eis a noite sutil, amiga do assassino; Ela vem como um cúmplice, a passo lupino; Qual grande alcova o céu se fecha lentamente, E em besta fera torna-se o homem impaciente."

Charles Baudelaire ${ }^{98}$

O devaneio poético propicia ao Eu um não-eu que encanta e que permite viver a confiança de se estar no mundo. Quando entregue a inumanidade mundana, as exigências sobre a função do real obrigam o homem a adaptar-se à realidade, a auto constituir-se como ela e a produzir obras factíveis. A divagação criadora, em sua própria essência de libertar-nos do concreto, é o testemunho de um encargo do irreal, que protege o psiquismo humano de um não-eu hostil. Mas há momentos para o artista em que o devaneio assimila o próprio real e o que ele percebe é absorvido pelo mundo imaginário. Pela imaginação, e não pela percepção, em virtude das sutilezas do irreal, reingressa na confiança perdida. Em Goeldi, as imagens do devaneio transmutavam-se em concretude na medida em que cenas visionárias se tornavam tangíveis nas ruas do Rio de Janeiro. O recurso utilizado pelo artista era "assimilar as formas reais por meio do desenho e transformá-las novamente em imagem" ${ }^{99}$. O traço agitado solicitava urgência para dominar o "ambiente convulso"

\begin{abstract}
"A paisagem brasileira me pareceu estranha, era como se eu nunca houvesse estado aqui. Procurei então assimilar as formas que, com a minha ausência, tinham mudado de fisionomia e de expressão. Desenhei muito para me assenhorear das formas ambientes, do novo mundo visual que ia ser a matéria de minha expressão. O que me interessava eram os aspectos estranhos do Rio suburbano, do Caju, com postes de luz enterrados até a metade na areia, urubu na rua, móveis na calçada, enfim coisas que deixariam besta qualquer europeu recém-chegado. Depois descobri os pescadores e toda madrugada ia para o mercado ver o desembarque do peixe eldesenhava sem parar."
\end{abstract}

\footnotetext{
${ }^{98}$ BAUDELAIRE, Charles. O crepúsculo vespertino. As flores do mal. P. 323

${ }^{99}$ SIQUEIRA, Vera Beatriz. Cálculos da Expressão. P.14.

${ }^{100}$ Idem, ibidem.

${ }^{101}$ Entrevista de Oswaldo Goeldi a Ferreira Gullar. Suplemento Dominical do Jornal do Brasil, em 12/01/1957. In: BRITO, Ronaldo. Oswaldo Goeldi. Coordenação de Silvia Roesler. Pg. 210.
} 
Quando João do Rio escreveu sobre a alma das ruas, informou a seus leitores que para compreender a psicologia urbana é preciso ter um curioso "espírito vagabundo", ser um "flâneur e praticar o mais interessante dos esportes a arte de flanar" 102 , que seria a "distinção de perambular com inteligência"103 para captar e compreender a fisionomia e o espírito desse "fator" da vida das cidades: a rua. Percebeu a volatilidade e fugacidade das cidades que se rendem a cada época, onde mapas se transformam radicalmente de um século a outro, concluindo que "as ruas são perecíveis como os homens". ${ }^{104} \mathrm{Na}$ obra A alma encantadora das ruas, João do Rio transforma a cidade em personagem, "literalizando o mundo urbano"105 e procurando em seu "caminho crítico pela cidade, elementos que possam ajuda-lo a completar a sua cartografia sócio urbana”. 106

Enquanto Baudelaire e Poe flanavam captando as angústias dos seres citadinos na multidão, percebiam que, apesar de todas as singularidades, esses homens não conseguiriam sair do que Benjamin chamou de círculo mágico do tipo social, ${ }^{107}$ que se submetiam ao automatismo lentamente alcançado e sedimentado por esta primeira modernidade que viabilizaria a desumanidade desenfreada do século posterior. A fantasmagoria angustiante destes homens autômatos que se multiplicavam pela Europa é representada por Baudelaire no poema Os sete velhos:

"Outro o seguia: barba, dorso, olhos, molambos, Enfim, tudo era igual, do mesmo inferno oriundo (...) Sete vezes contei, minuto após minuto, Esse sinistro ancião que se multiplicava!",108

\footnotetext{
${ }^{102}$ RIO, João do. A alma encantadora das ruas. P.31.

${ }^{103}$ Idem, ibidem.

${ }^{104}$ Idem, ibidem.

${ }^{105}$ RODRIGUES, Antonio Edmilson Martins. João do Rio: a cidade e o poeta, o olhar de flâneur na belle époque tropical. P.41.

106 Idem, ibidem.

${ }^{107}$ BENJAMIN, Walter. Nota sobre os "Quadros Parisienses". Baudelaire e a modernidade. P. 200

${ }^{108}$ BAUDELAIRE, Charles. Os sete velhos. As flores do mal. P. 307
} 


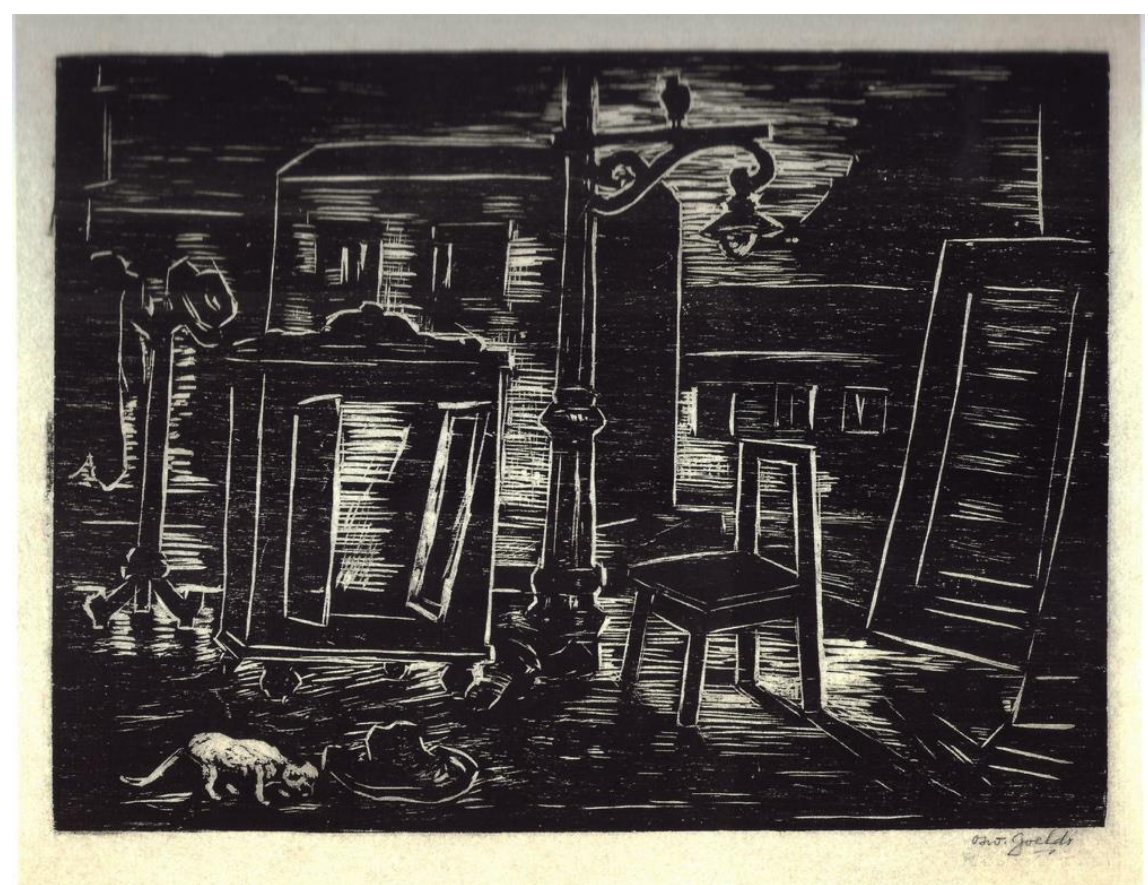

Figura 43: GOELDI, OSWALDO. Sem título, 1950.

Xilogravura, 20,5 x $27,7 \mathrm{~cm}$.

O espaço urbano de Goeldi não se insere na designação de lugar público que faculta a convivência social. Há uma ambiência de solidão e silêncio onde transeuntes passam por ruas abandonadas sem se perceberem, homens invisíveis entre si que caminham determinados para algum lugar distante da cidade que conhecemos. Não estão inseridos na multidão, mas, escravos do automatismo social, vagam por madrugadas vazias em ruas que têm almas próprias, silenciosas e espectrais. $\mathrm{O}$ olhar de Goeldi acompanha esses passantes a flanarem juntos pelos becos desventurados da cidade. Assim como casas e ruas, a cidade de Goeldi também se torna personagem.

Há uma certa transferência do interior dos casarios para o lado externo das ruas. A interioridade do $\mathrm{Eu}$ extravasa para uma dimensão anárquica, meio fantástica, mas que é muito mais real do que parece. Um sótão e um porão de itens que aparecem perdidos pela cidade, fora do lugar íntimo da nossa conveniência imaginária. Objetos soltos, caídos, quebrados, no meio da ventania, cercados por urubus e ratos, dão o tom cruel de abandono e miséria dos subúrbios brasileiros. Como em Sem título (Fig. 43), onde cadeira, chapéu, armário e até um cabideiro encontram-se espalhados em plena rua, inspirados em despejos e mudanças da periferia carioca, retratam a cidade invisível que permaneceu à margem do processo de modernização urbana do início do século XX. O interior e a 
intimidade das casas, observados pelos olhos imóveis das próprias ao fundo, têm o silêncio sutilmente quebrado pelo cachorro que fareja o chapéu, trazendo alguma ideia de realidade à cena absurda. Em Rua Molhada (Fig. 44), a disposição geométrica das formas é abalada pelos postes cambaleantes, que modulam a percepção de desordem, intensificada pela lata derrubada e pelo guarda-chuva deixado no meio do caminho.

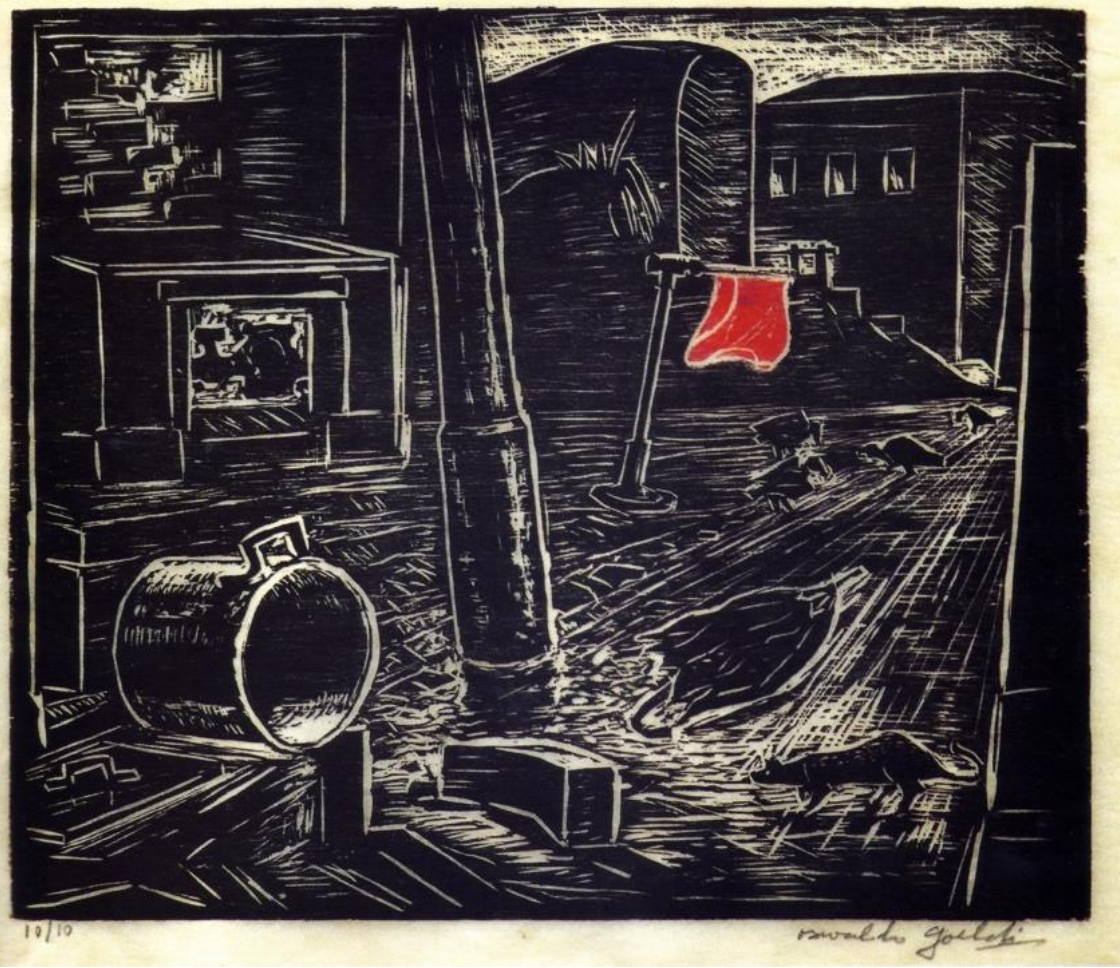

Figura 44: GOELDI, OSWALDO. Rua molhada, 1937. Xilogravura, $21 \times 27,5 \mathrm{~cm}$. 


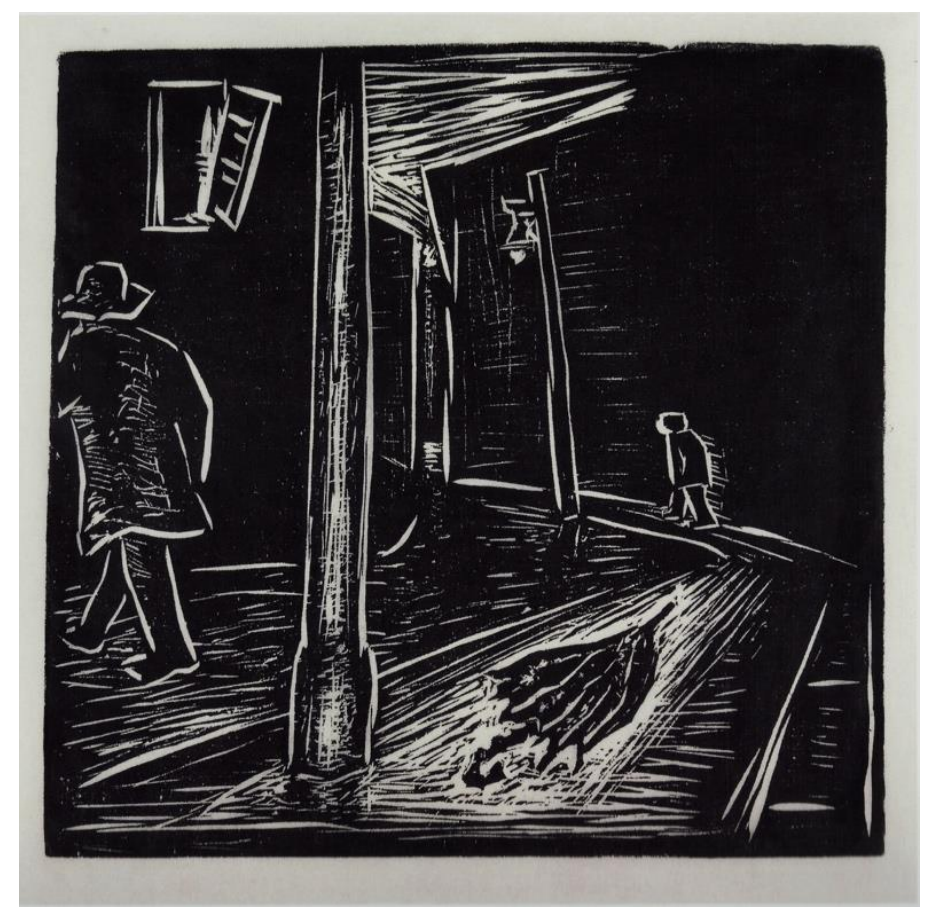

Figura 45: GOELDI, OSWALDO. A morte do guarda-chuva, 1937. Xilogravura, 25 x $24,5 \mathrm{~cm}$

Personagem-objeto também atuante em A morte do guarda-chuva (Fig. 45), a sombrinha representa uma inversão no simbolismo de proteção surgindo, ironicamente, afogada no próprio elemento de que deveria nos resguardar. A morte, como se sabe, era tema romântico recorrente, assíduo na maioria dos artistas expressionistas germânicos. Em Goeldi, a morte assume uma posição ora simbólica, ora irônica, muito presente no ambiente hostil e fantasmagórico de várias gravuras, no mar revolto, nos urubus, nas ruas frias, úmidas e vazias das madrugadas.

A perplexidade diante da cidade, que não conseguia reconhecer, dominava sua curiosidade sensível. Na representação do agouro sistemático do urubu sempre pousado em obras como Urubus (Fig. 46), de 1932, a solidão e a finitude deixam de ser meros atributos expressivos para atestarem a própria condição existencial. Operando com transgressões e distorções no sistema perspectivo, compõe o vazio da cena pela contenção. A mesma contenção nos devaneios e na imaginação que o motivou a trocar os desenhos pela xilogravura, de lugares não vistos, de ruas e casas que impunham com suas estruturas e sombras "um silêncio 
de mau agouro e crime" ${ }^{\text {109 }}$. Com precisão nos traços e nos golpes de goiva, visível através da luz que emana por trás da superfície negra, domina e contém a cena nos finos filetes esculpidos, evitando assim que se estabeleça o caos ${ }^{110}$. Apesar de manter a unidade espaço-tempo da cena pós-renascentista ${ }^{111}$, já nesta época, consegue compreender o alcance do espaço moderno, extrapolando a cena pelos limites da matriz.

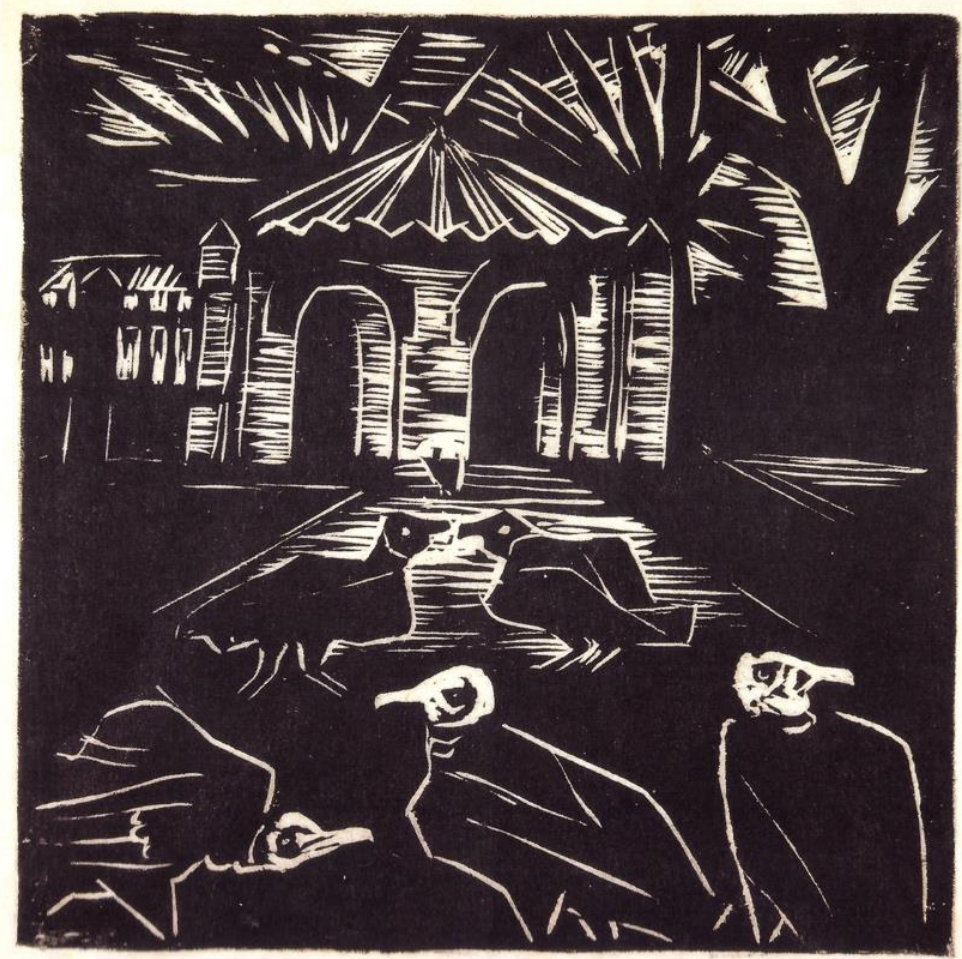

Figura 46: GOELDI, OSWALDO. Urubus, circa 1929.

Xilogravura, $14,8 \times 14,8 \mathrm{~cm}$

A assiduidade de aspectos relacionados à morte se intensificaria na obra goeldiana com a Segunda Grande Guerra, detonando um período aflitivo que passou a interferir na vida cotidiana do artista com notícias desoladoras que chegavam da Europa diariamente. O afastamento do Rio foi providencial, fazendo da ambiência baiana a distração necessária por um período de exílio temporário, de lá trouxe desenhos aquarelados, como Baiana (Fig. 47). Convidado a ilustrar Dostoievsky, Goeldi uniu a tragicidade da temática em pauta ao ambiente carregado de sofrimentos da Guerra. Sobre a facilidade com que criou estas

\footnotetext{
${ }^{109}$ MACHADO, Aníbal. Goeldi. Coleção Artistas Brasileiros. P.6.

${ }^{110}$ RAMOS, Nuno. Goeldi: agouro e libertação. Catálogo da exposição A noite morta, 1995.

${ }^{111}$ BRITO, Ronaldo. Oswaldo Goeldi, nossa sombra. Coordenação Silvia Roesler. P.20.
} 
ilustrações, Raquel de Queiroz escreveu: "Parece que o mundo dostoievskiano é um ambiente seu, uma atmosfera propícia onde mergulha sem se sufocar" ${ }^{, 12}$, afinizado que estava com a miserabilidade da condição humana dos personagens. Para Rodrigo Naves, estas ilustrações (Fig. 48) se distanciaram muito de outros importantes trabalhos do artista, aproximando-se mais das formas expressionistas canônicas ${ }^{113}$, facilitadas pela própria poética do escritor russo. Além de ilustrações para jornais e livros, Goeldi desenhou paralelamente a série As luzes se apagam, agitam-se os monstros, simbolizando a dor e o repúdio à eclosão das forças instintivas do homem nos conflitos, com técnica inspirada em cartões de Seurat, ${ }^{114}$ utilizando efeitos de luz que propiciavam atmosfera funesta às imagens. Ainda na mesma época de incertezas, desenvolveu a série de xilogravuras Balada da Morte (Fig.51) para a revista Clima, de São Paulo. Segundo Reis Jr, a partir deste período obscurecido pela Guerra, passa a perseguir o tema da morte obsessivamente $^{115}$, mergulhando em uma sombria imaginação de amargura.

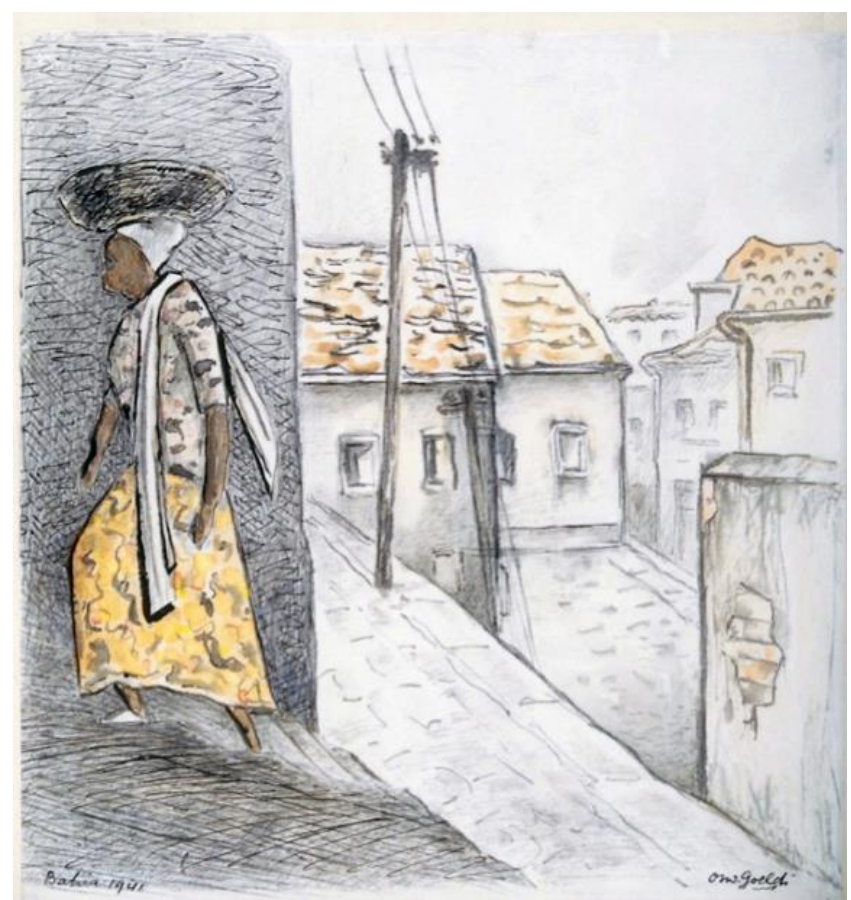

Figura 47: GOELDI, OSWALDO. Baiana, 1941. Bico de pena e aquarela, $27,5 \times 25,5 \mathrm{~cm}$.

112 QUEIROZ, Raquel de. Exposição de gravuras. Jornal Folha Carioca, Rio de Janeiro, 01/07/1944.

${ }^{113}$ NAVES, Rodrigo. Goeldi. P.30

${ }^{114}$ REIS JÚNIOR, José Maria dos. Goeldi. P.38.

${ }^{115}$ Idem. P.39. 


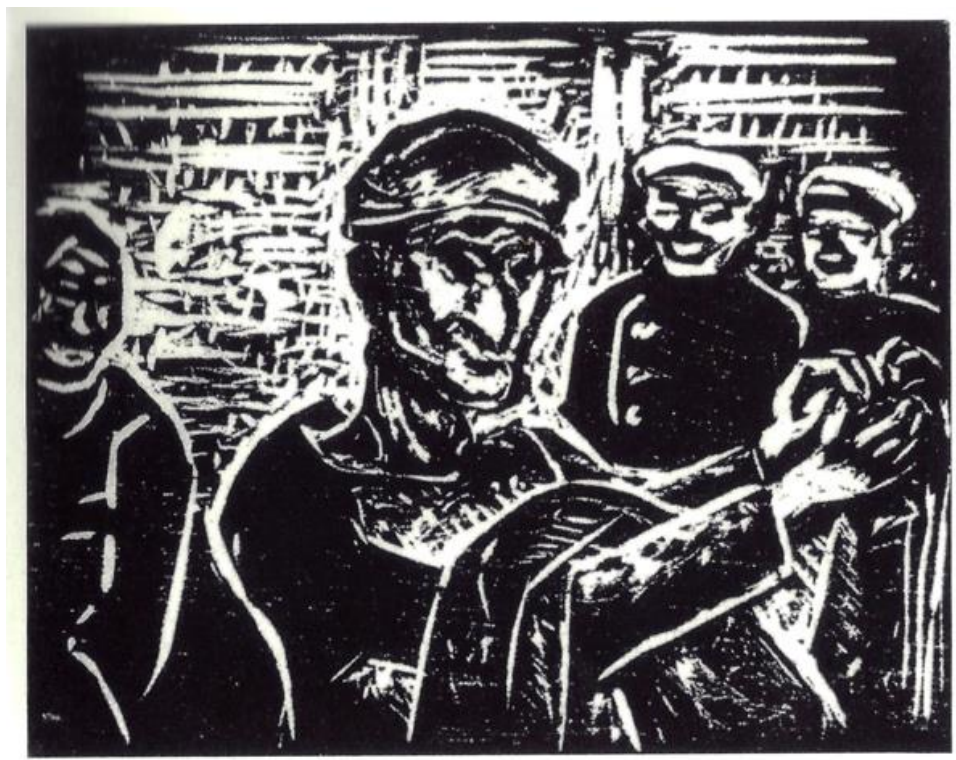

Figura 48: GOELDI, OSWALDO. Ilustração para Recordação da Casa dos Mortos, 1941.

Os dias calamitosos abalavam a sensibilidade e produção de artistas em todo

o mundo. No Brasil, foram mais fortemente afetados os que tinham, além das afinidades expressionistas, o olhar estrangeiro para os eventos belicosos, como Goeldi e Lasar Segall. Em sua série Visões de Guerra (Figs. 49 e 50), um significativo conjunto de 75 desenhos aquarelados, Segall representou com intensidade a agonia e a desesperança em relação aos conflitos e seus desdobramentos na sociedade. A experiência trágica das batalhas de trincheiras da Primeira Guerra Mundial, vistas de perto por ambos na Europa, assombravam psiquicamente a percepção poética destes artistas que passaram a expressar mais frequentemente a morte em seus trabalhos, mas por formas diferentes. As criações mortíferas de Goeldi não eram macabras quanto às gravuras Disparates de Goya (Fig. 2), nem irônicas como as máscaras de Ensor (Fig. 1), caminharam para o tom satírico sobre o ridículo das vaidades e dos absurdos da própria condição humana. Segall concentrou seus desenhos no horror das perdas irrecuperáveis, na paixão pungente pelas vítimas dos massacres, imbuído pela tradição judaica de suas heranças familiares. 


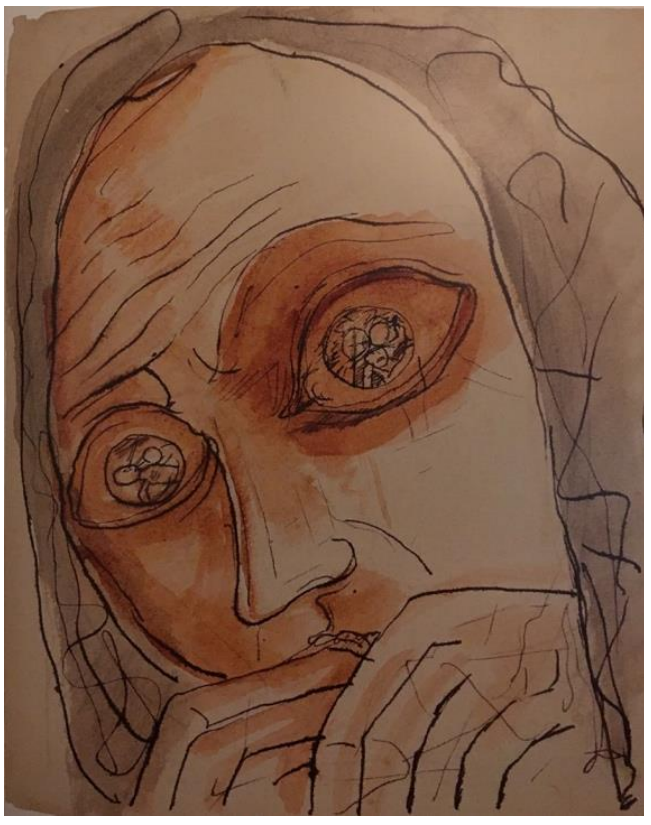

Figura 49: SEGALL, LASAR. Visões de Guerra. 1941-1943.

Tinta preta e terra de siena a pena e aguada sobre papel, 19,4 x $15,5 \mathrm{~cm}$.

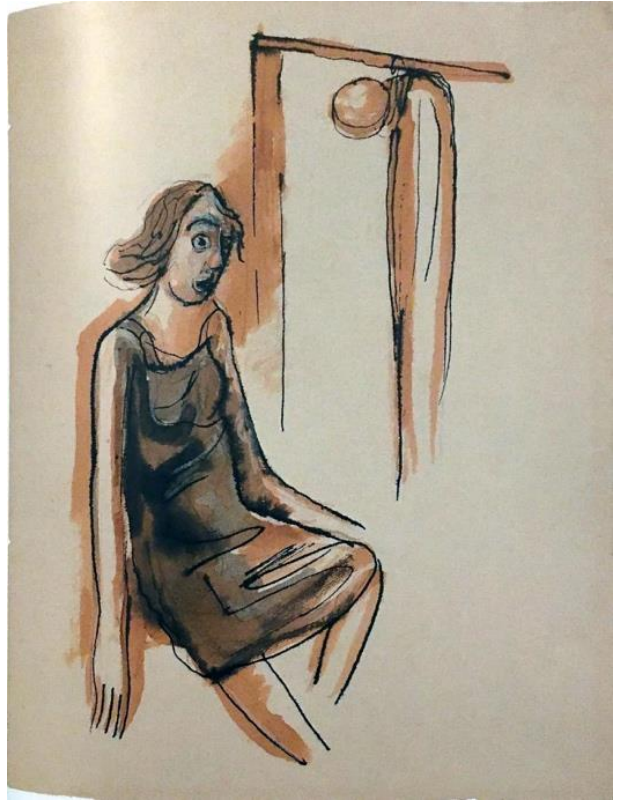

Figura 50: SEGALL, LASAR. Visões de Guerra. 1941-1943.

Tinta preta a pena e sépia a pincel sobre papel, $19,5 \times 15,6 \mathrm{~cm}$.

Goeldi se preocupava mais com a realidade estética da gravura do que com a representação mimética do mundo. Cenas e personagens poderiam ser apenas pretextos para a execução de uma obra meticulosamente calculada, tecnicamente experienciada, onde o gesto se integrava com o objeto numa proximidade com o conceito bruckeano de arte e vida. O fantástico se retroalimentava com visionarismo cotidiano da cidade, contudo, não trazia as deformações do imaginário simbolista dos artistas germânicos. A expressão goeldiana se dava por signos de uma imensidão íntima complexa, cheia de poesia satírica e obscura, relatada por fragmentos do real em um "figurativismo de extrema redução"116. A linguagem criada por Goeldi sinalizava "uma versão pessoal de minimalismo expressionista, tirando o máximo de proveito dramático de um repertório formal restrito, graças a breves distorções e desvios"117.

\footnotetext{
${ }^{116}$ MARQUES, Maria Eduarda Castro Magalhães. Goeldi e a cena urbana moderna: solidão e melancolia. Revista Gávea, vol. 6, dezembro de 1988, P.14.

${ }^{117}$ BRITO, Ronaldo. Oswaldo Goeldi, nossa sombra. P. 35
} 


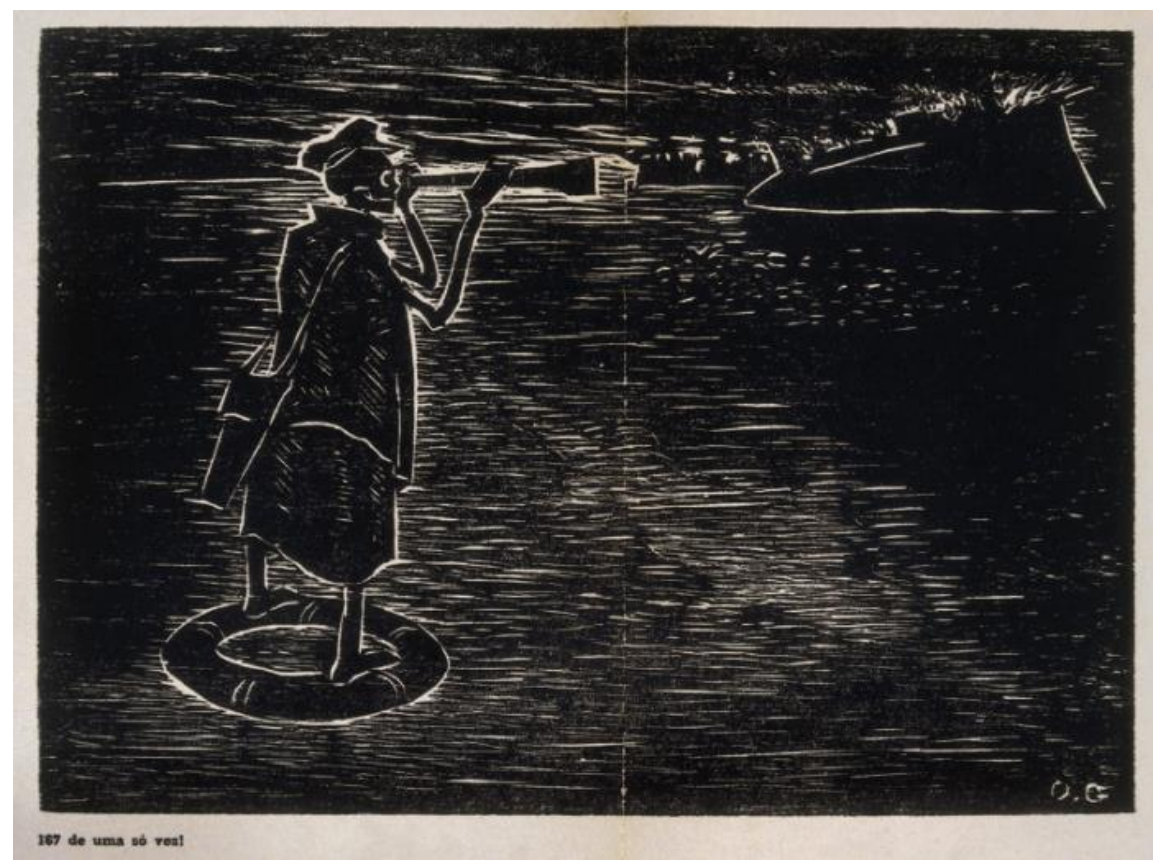

Figura 51: GOELDI, OSWALDO.167 de uma só vez.

Série Balada da Morte, 1944.

Xilogravura, 16 x $22 \mathrm{~cm}$.

A imagem poética testemunha que o devaneio pode transmitir a sensação de uma alma que descobre o seu mundo, onde gostaria de viver, onde seria digno viver. As representações imagéticas da cidade e da morte em Goeldi passavam por uma rua que João do Rio descreveu como uma velha conhecida de todos e tão eterna como o medo, a infâmia e a inveja:

"Qual de vós não quebrou, inesperadamente, o ângulo em arestas dessa rua? Se chorastes, se sofrestes a calúnia, se vos sentistes ferido pela maledicência, podereis ter a certeza de que entrastes na obscura via! Ah! Não procureis evita-la! Jamais o conseguireis. Quanto mais se procura dela sair, mas dentro dela se sofre. E não espereis nunca que o mundo melhore enquanto ela existir. Não é uma rua onde sofrem apenas alguns entes, é a rua interminável, que atravessa cidades, países, continentes, vai de polo a polo; em que se alceiam todos os ideais, em que se insultam todas as verdades, onde sofreu Epaminondas e pela qual Jesus passou. Talvez que extinto o mundo, apagados todos os astros, feito o universo treva, talvez ela ainda exista, e os seus soluços sinistramente ecoem em total ruína, rua das lágrimas, rua do desespero - interminável rua da Amargura..." 118

${ }^{118}$ RIO, João do. A alma encantadora das ruas. P.51. 


\title{
4. \\ Conclusão
}

\author{
"Não fiz da gravura uma forma mecânica, \\ ainda tenho esperanças, faço descobertas e \\ gravo com a mesma satisfação de há 40 anos". ${ }^{119}$
}

Oswaldo Goeldi

A construção de uma linguagem efetivamente moderna na arte brasileira manifesta-se na autenticidade de obras como a de Oswaldo Goeldi. Mas ao compara-la, principalmente as xilogravuras, com alguns trabalhos de seus contemporâneos brasileiros dos anos 1920 e 1930 parece que confirmamos o axioma euclidiano de que duas retas paralelas só podem se encontrar no infinito. Inserir a produção goeldiana no contexto do projeto modernista brasileiro será sempre uma conjectura problemática. Ao se conservar afastado da ideologia dominante de preocupação com uma arte nacional, de formação plástica incipiente, pré-cubista, permaneceu por toda sua caminhada artística como um expoente da estética expressionista - sem mudanças drásticas na direção de sua poética como foi o caso de Anita Malfatti, sem se envolver indiretamente com as questões da brasilidade como Lasar Segall.

Os contrastes nos trabalhos de Goeldi não ficam apenas restritos ao plano visível de suas gravuras, à dicotomia de luz e sombra. Sua produção destoava da paleta tropical em voga e, consequentemente, do meio artístico modernista. A própria escolha da técnica da xilogravura chocava-se com a visão positivistaprogressista que permeava o Modernismo, além de ser muito pouco conhecida e valorizada. "Senti-me, mais ou menos, como Gauguin na ilha"120, referia-se à nãoadaptação ao meio intelectual na volta ao Brasil. Como a inclinação nacionalista do primeiro modernismo é oposta à postura crítica expressionista em relação ao progresso, a produção de Goeldi surge como um ponto de reflexão, dada a

\footnotetext{
${ }^{119}$ Entrevista de Oswaldo Goeldi a Anna Letycia. Revista Paratodos, setembro de 1956. In: ZÍLIO, Carlos (Org.). Oswaldo Goeldi. Solar Grandjean de Montigny, PUC-Rio. Pg. 115

${ }^{120}$ Idem, ibidem.
} 
desconfiança do Expressionismo em relação à civilização industrial e mercadológica.

A influência do primitivismo e das "máquinas" na arte moderna recebeu uma adaptação particular na cultura brasileira. Na Europa, os artistas estavam inseridos numa sociedade industrial consolidada e cotidiana, o primitivo ficava no plano teórico dos etnólogos e dos museus como um tipo de elemento exótico. No Brasil, esses conceitos estavam interligados, uma vez que o primitivo sempre conviveu com a cidade. Tal familiaridade com a cultura originária ajudou na assimilação dos processos artísticos europeus que representavam ruptura profunda com o meio social e as tradições culturais. Na teoria, a valorização de aspectos culturais permitiria a libertação do olhar dos artistas, até então limitado pelo academicismo, permitindo encontrar os traços de distinção dos modelos europeus em sua própria realidade cultural. Mas, na prática, o caminho por esse processo seria árduo e problemático. Na condição de estrangeiro, Goeldi estava livre para encontrar-se com o primitivo e o exótico fora do confinamento dos museus europeus ou de viagens ao interior em busca de raízes culturais.

Na segunda fase do Modernismo, quando as questões políticas abarcam o movimento, a orientação social recrudesceria o discurso nacionalista. Neste período, a ética expressionista passa a fazer algum sentido e a posição que Goeldi ocupava na solar arte moderna brasileira, apesar de marginal, surgia como singular alternativa à brasilidade. Para os críticos brasileiros da época, Goeldi seria uma opção sombria e original ligada à excentricidade fantástica expressionista, um artista de "visões fortes e impressionantes", segundo Mario de Andrade $^{121}$. Para os críticos europeus, a expressão do exotismo e exuberância tropicais impressionavam, assim como a expressão dos costumes e das misérias da metrópole do sul.

Obstinado por uma experimentação técnica rigorosamente calculada, alimentada por uma intensa "vontade artística", 122 , integrou criação e processo

\footnotetext{
${ }^{121}$ ANDRADE, Mario de. Apud SIQUEIRA, Vera Beatriz. Olhares contaminados.P.475.

${ }^{122}$ Conceito primeiramente usado pelo historiador da arte Alois Riegl, e depois por seu discípulo Wilhelm Worringer, sobre a obra de arte como representação do impulso subjetivo que domina a razão. A teoria de Worringer sobre expressão e empatia serviu como uma das bases filosóficas da arte expressionista.
} 
artesanal da xilogravura como sistema expressivo de sua poética. $\mathrm{O}$ artista flâneur que "clicava" os instantes circunstanciais da exótica e caótica modernidade carioca, alçados à superfície a partir das distorções expressivas de sua imensidão íntima, dava "visão nova a coisas existentes"123, deflagrava momentos de explosão da claridade, por céus e mares que faziam "vibrar as coisas na terra" ${ }^{124}$, tornando eterno o que parecia transitório. Confirmaria, desse modo, a profecia baudelairiana de subsistência histórica: "para que toda a Modernidade seja digna de tornar-se Antiguidade, é necessário que dela se extraia a beleza misteriosa que a vida humana involuntariamente lhe confere." ${ }^{25}$ O primeiro grande reconhecimento crítico viria com a primeira Bienal de São Paulo, em 1951, seguido de outras importantes premiações até a sua morte. Foi inspiração de várias gerações de gravadores brasileiros, de Lívio Abramo a Marcelo Grassmann. Alguns críticos e pesquisadores pautam proximidades com os últimos trabalhos de Iberê Camargo e a pintura de Amílcar de Castro ${ }^{126}$. Mas seria principalmente graças às apropriações de artistas como Lygia Pape e Nuno Ramos, além de exposições retrospectivas, filmes, homenagens póstumas, livros, artigos, websites, dissertações e teses acadêmicas que Goeldi, considerado o único artista realmente moderno da primeira metade do século XX, seria extraído de certa obscuridade marginal para o protagonismo das revisões críticas e historiográficas de nossa modernidade. ${ }^{127}$

\footnotetext{
${ }^{123}$ MACHADO, Anibal M. Goeldi. Coleção Artistas Brasileiros. P.6.

${ }^{124}$ Idem. P.8.

${ }^{125}$ BAUDELAIRE, Charles. Sobre a modernidade. P.27.

126 Ver em: BRITO, Ronaldo, Oswaldo Goeldi, nossa Sombra; SIQUEIRA, Vera Beatriz, Cálculo da Expressão e COTRIM, Cecília, Romantismo e atualidade nas obras de Oswaldo Goeldi e Iberê Camargo.

${ }^{127}$ Em seu livro Oswaldo Goeldi, iluminação e ilustração, a filósofa Priscila Rufinoni questiona revisões críticas e historiográficas que colocam Goeldi em posição de isolamento em relação no nosso modernismo. Segundo a autora, ao trabalhar como ilustrador para jornais e revistas, "sem maiores compromissos", o artista sai da marginalidade e passa a desfrutar dos benefícios da divulgação cultural dos veículos de comunicação de massa. A ambiguidade se daria por Goeldi compartilhar "utopias estéticas", ao mesmo tempo em que mantinha contratos de ilustrações periódicas que "permitiram a carreira de desenhista-gravador antes mesmo da formação de um mercado de arte". Abordamos, anteriormente, como as ilustrações para periódicos e livros ajudaram Goeldi a romper, de certa forma, com a marginalidade completa e a mantê-lo financeiramente para que desenvolvesse, paralelamente, uma pesquisa livre do contexto da "encomenda". Entretanto, mesmo no desenvolvimento do ofício da ilustração, Goeldi conservava o mesmo padrão ético e estético, a mesma obsessão pela experimentação e pela qualidade do processo em sua totalidade, acompanhando pessoalmente, por exemplo, impressões de livros como garantia de resultado final satisfatório. Parece-nos também problemática a argumentação sobre o artista ter se aproveitado das vantagens do "mercado", o que entra em choque com a própria biografia goeldiana. Além dos recursos como ilustrador terem se apresentado, muitas vezes,
} 
$\mathrm{Na}$ década de 1950, quando integrava o grupo Frente ${ }^{128}$, Lygia Pape produziu uma série de xilogravuras que manipulavam a relação entre luz e linha, o que suscitaria desdobramentos ao longo de sua obra. Em Tecelares (Figs. 52 e 53), a passagem do preto ao branco, numa dicotomia de interior ao exterior, “equivale à passagem da matéria à luz, do plano ao espaço" ${ }^{129}$. O processo, segundo a própria artista, apresentava-se inicialmente como uma superfície negra, nela abria frestas de luz que faziam a figura começar a surgir progressivamente até encontrar o objeto da gravura: "Esta, por exemplo, é a diferença do meu trabalho com o de Lygia Clark, que rompeu com a moldura a partir da linha orgânica. Eu fui cavando o preto até chegar ao branco, que era, na verdade, o espaço externo" ${ }^{\prime 130}$.

Há um espaço externo na luz goeldiana, um todo iluminado, que sofre a obliteração do negro profundo dando forma às figuras e ao movimento das cenas. A influência de Goeldi na concepção de Tecelares (Figs. 52 e 53) é plausível, apesar de Pape ter afirmado que nessa época ainda não o conhecia ${ }^{131}$. Mais tarde, um diálogo formal entre a obra dos dois artistas não seria viável, pois o gravurista não considerava o geometrismo dos processos construtivos como forma expressiva, abominando "tudo em que houvesse um sentido de espaço estruturado e plano" ${ }^{\prime 132}$. O entusiasmo de Pape pela xilogravura era de ordem experimental: imprimia uma única vez as gravuras, o que interessava era o pleno domínio do processo desde a escolha da madeira. Preferia peças retiradas de caixas de pinho europeu, que, inusitadamente, traziam mantas de bacalhau para o Brasil e eram recolhidas em um armazém. $\mathrm{O}$ encantamento com os veios destas peças remete ao apreço de Goeldi pela apropriação dos recursos intrínsecos da matéria: "tinha uns olhos, umas texturas lindíssimas e que eu, então, incorporava no meu trabalho" ${ }^{\text {133 }}$. A gravura tornou-se uma possibilidade de pesquisa para a artista, rigorosamente

insuficientes para o próprio sustento do artista, o reconhecimento efetivo de crítica e de público ocorreria apenas na última década de sua vida.

${ }^{128}$ Segmento carioca do concretismo brasileiro, liderado por Ivan Serpa e Mario Pedrosa, cuja primeira exposição, em 1954, na Galeria Ibeu, já contava com a participação da artista Lygia Pape, além de Lygia Clark, Aluísio Carvão, Décio Vieira, Ferreira Gullar, entre outros.

${ }^{129}$ OSÓRIO, Luiz Camillo. Lygia Pape: Experimentação e resistência. Olhar à margem: caminhos da arte brasileira. P.146.

${ }^{130}$ Entrevista de Lygia Pape a Frederico Morais. O Globo. Rio de Janeiro, 22/07/1975.

${ }^{131}$ Entrevista de Lygia Pape à Paulo Venâncio Filho, Glória Ferreira e Ronald Duarte. Dossiê Lygia Pape. Revista Arte \& Ensaios da EBA-UFRJ. P. 7.

${ }^{132}$ Idem, ibidem.

${ }^{133}$ Idem. P.8. 
fiel aos conceitos do espaço construtivo - até o corte da madeira era precisamente em linha reta - com a peculiaridade de trabalhar sobre a matéria como uma pintura, com figuras "ambivalentes", a parte de cima igual a de baixo, forma única cortada com apenas uma faca. Com o tempo, os brancos foram crescendo e os efeitos de luz desprezados, as matrizes começaram a ser trabalhadas como escultura, com desdobramentos em múltiplas poéticas.

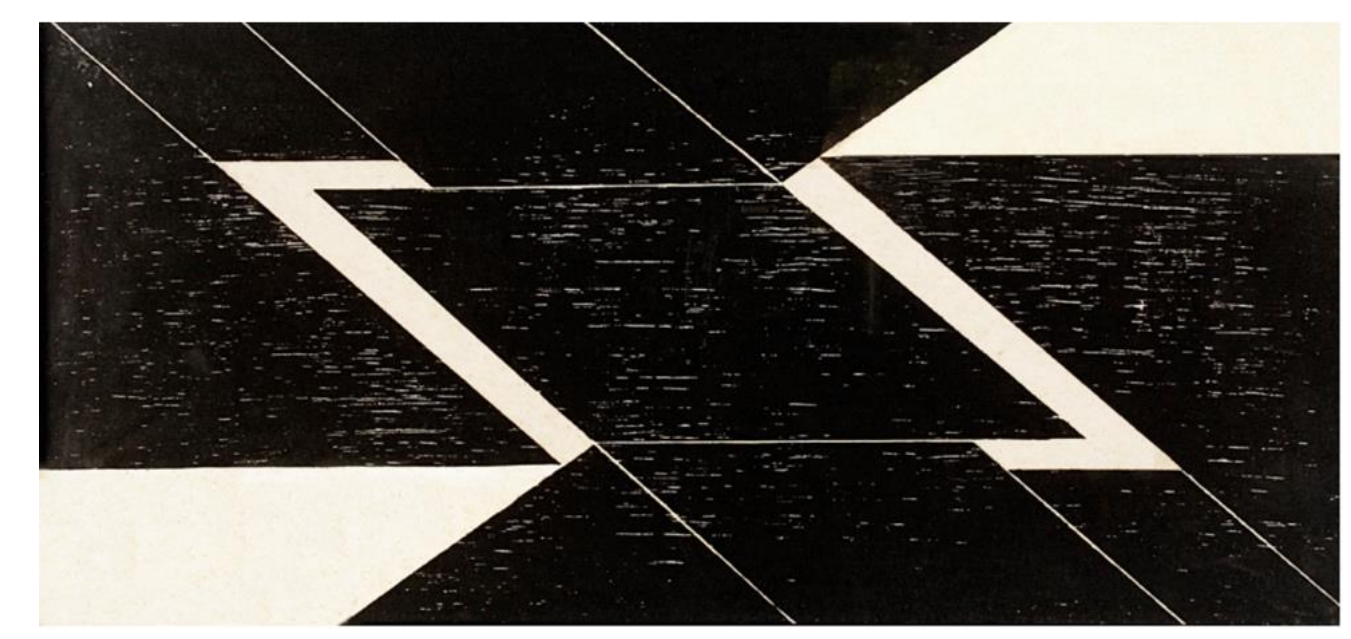

Figura 52: PAPE, LYGIA. Tecelar, 1955.

Xilogravura, 31 x 43,3 cm.

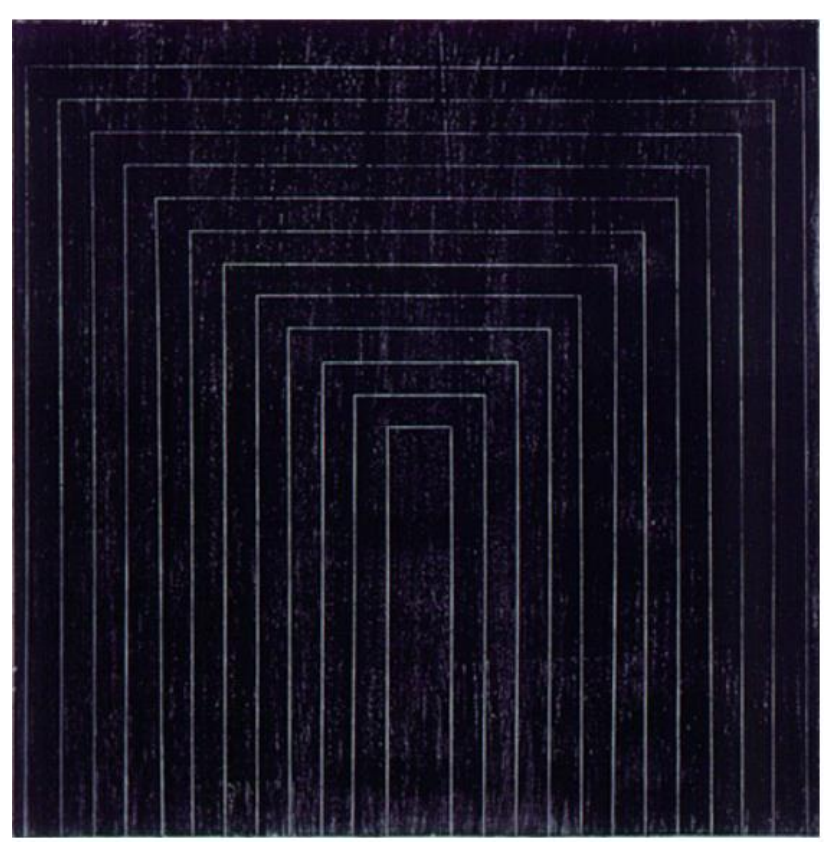

Figura 53: PAPE, LYGIA. Tecelar, 1957. Xilogravura, 50 x $50 \mathrm{~cm}$. 
Em seu filme O guarda-chuva vermelho ${ }^{134}$, de 1971, Pape relaciona gravuras de Goeldi a poemas de Manuel Bandeira e Murilo Mendes imprimindo, através da linguagem cinematográfica, a significativa referência do artista como parte integrante e fundamental da arte moderna brasileira, acompanhado de escritores que também se debruçaram na paisagem humana da modernidade como condição existencial. A identificação com as margens e com a resistência solitária aproximou a artista contemporânea do gravurista, revelando "uma simpatia por um Brasil noturno, austero, crepuscular, nada tropical, que de certo modo também compõe a personalidade multifacetada de Lygia Pape". ${ }^{135}$ A participação de Hélio Oiticica como narrador ratifica a atualidade de Goeldi nos movimentos contemporâneos dos anos 1950 e 1960, além de simbolizar uma certa legitimação do processo criativo "gestual" como impulso expressivo. No filme-homenagem, inspirado em Chuva (Fig. 34), com seleção apurada de poemas, gravuras e da seleção dos próprios artistas que integraram a produção, Pape corrobora não só a influência de Goeldi em sua obra, como o seu papel singular no cenário moderno brasileiro, dando-lhe um protagonismo até então inédito.

A exposição Noite Morta, de 1995, com curadoria de Nuno Ramos, Paulo Pasta e Fábio Miguez, mais uma vez, uniu Goeldi aos poemas de Bandeira, num sentido menos nostálgico e mais relacionado a presença da morte como símbolo do descaso quanto às misérias humanas. Apesar de haver em Bandeira um desejo por "mais vida", estranho a Goeldi, há um interessante ponto de contato entre os dois artistas que "descortinam à cultura brasileira a hipótese de um mau destino" ${ }^{136}$. Nos desenhos espectrais de Goeldi, abandono e esquecimento formam o eixo dos trabalhos onde a tristeza surge como condição e, não, atributo ${ }^{137}$. Na demasiada espacialidade que torna os lugares mais profundos e isola as criaturas entre si e em relação ao entorno, a ambiência traz sempre a impressão de

\footnotetext{
${ }^{134}$ PAPE, Lygia. O Guarda Chuva Vermelho. 35mm, 16mm, cor, 9', vídeo. Apesar de alguns artigos datarem o filme como produção de 1966, o site oficial do Projeto Lygia Pape informa o ano de 1971.

135 OSÓRIO, Luiz Camillo. Lygia Pape: Experimentação e resistência. Olhar à margem: caminhos da arte brasileira. P.159

${ }^{136}$ Catálogo da exposição Noite Morta: Manuel Bandeira e Oswaldo Goeldi, Caixa Cultural do Rio de Janeiro, 1994. Fez parte do conjunto de exposições em comemoração ao centenário de Goeldi, em 1995.

${ }^{137}$ RAMOS, Nuno. Goeldi: Agouro e Libertação. Catálogo da exposição Noite Morta: Manuel Bandeira e Oswaldo Goeldi, Caixa Cultural do Rio de Janeiro, 1994. P. 37.
} 
desolação e silêncio, associada ao próprio signo da morte, como bem descreveu Manuel Bandeira:

“(...) O demônio sutil das nevroses enterra

A sua agulha de aço em meu crânio doído.

Ouço a morte chamar-me e esse apelo me aterra...

Minha respiração se faz como um gemido.

Já não entendo a vida, e se mais a aprofundo,

Mas a descompreendo e não lhe acho sentido.

Por onde alongue o meu olhar de moribundo,

Tudo a meus olhos toma um doloroso aspecto:

E erro assim repelido e estrangeiro no mundo.

Vejo nele a feição fria de um desafeto.

Temo a monotonia e apreendo a mudança.

Sinto que a minha vida é sem fim, sem objeto...

- Ah, como dói viver quando falta a esperança! “138

Por meio de uma multiplicidade de formas, Nuno Ramos fez outras homenagens e referências à Goeldi com apropriações e, mesmo, releituras conceituais da cena urbana goeldiana. Em uma trajetória marcada pela negação dos limites da arte, Ramos reúne fragmentos de um mundo esfacelado, procura dar continuidade ao que parece descontínuo, cria diálogos entre matérias e formas díspares, como se nos convocasse à reflexão sobre a contradição empírica: afinal, os limites da contradição também devem ser superados. A dramaticidade do mundo expressivo de Ramos é da ordem do fabuloso e do superlativo, e uma investigação sobre as ações do tempo parece estar sempre presente em seus trabalhos - seja no campo físico, seja no histórico - como em suas homenagens a Goeldi.

Em Para Goeldi 1 (Figs. 54 e 55) ${ }^{139}$, de 1996, acompanhando uma série de desenhos a carvão e giz, três esculturas fundidas em bronze com vidro derretido derramado sobre elas, referenciavam objetos muito frequentes nas gravuras: mala, cesto e cadeira. Além de uma forma de urubu impressa em areia e silicato, e intervenções de fumaça sobre cópias de gravuras e desenhos, em uma alegoria

\footnotetext{
${ }^{138}$ Catálogo da exposição Noite Morta: Manuel Bandeira e Oswaldo Goeldi, Caixa Cultural do Rio de Janeiro, 1994. Fez parte do conjunto de exposições em comemoração ao centenário de Goeldi, em 1995.

${ }^{139}$ Instalação exposta na Galeria AS Studio, São Paulo.
} 
quase ritualística sobre imagens consagradas da obra goeldiana. Em Para Goeldi 2 (Fig. 56) ${ }^{140}$, de 2000, moveis usados sofrem intervenção de lâminas de granito e vidro incrustados nas peças. A gravura Tarde, reproduzida e ampliada, é cavada no chão de cimento como uma matriz xilográfica. As partes negras são preenchidas por óleo queimado e as brancas são os fragmentos do próprio cimento. A mesma técnica foi utilizada por Ramos na mostra Silêncio: Para Goeldi 4 (Fig. 58) ${ }^{141}$, de 2008, onde a gravura Silêncio foi também trabalhada no chão, mas com intervenção de placas de granito. Utilizando, nestas intervenções, materiais de maior resistência e durabilidade, encrustados no chão, o artista contemporâneo faz uma alusão à perenidade da obra goeldiana. Em Mocambos: Para Goeldi 3 (Fig. 56), de 2003, fez uma sobreposição de fotografias de São Paulo e gravuras de Goeldi, onde cenas modernas e contemporâneas passam a dividir o mesmo espaço em um efeito de espelho, como se a cidade se mantivesse com suas sombras.

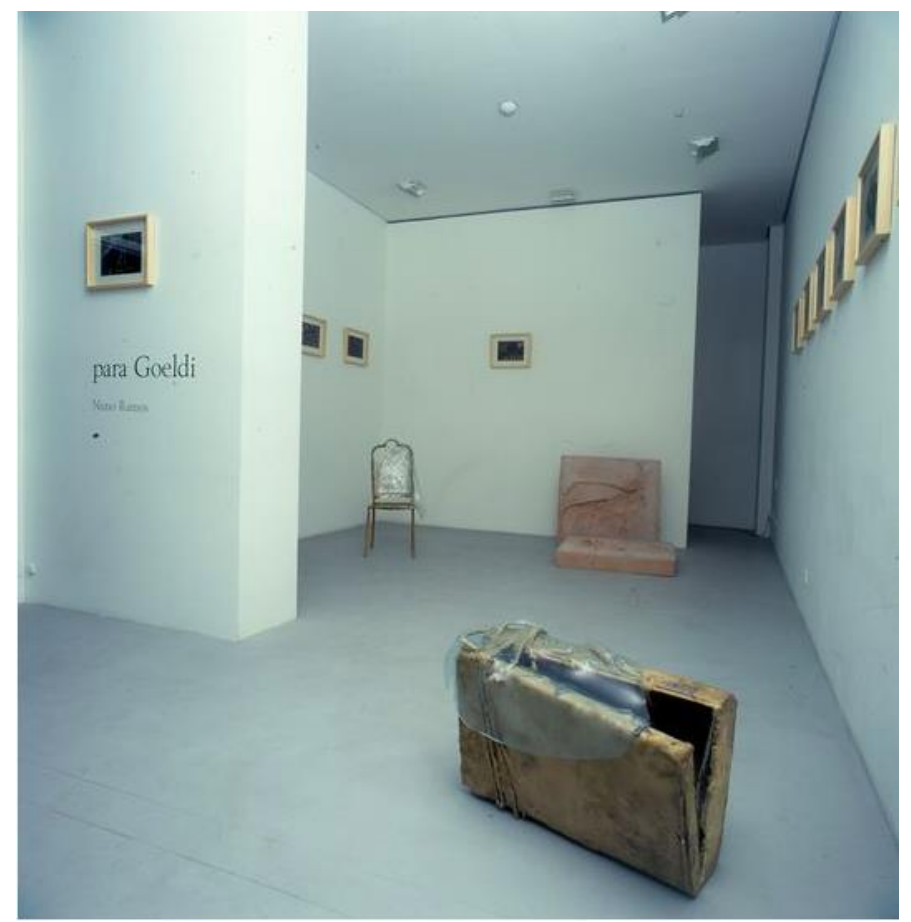

Figura 54: RAMOS, NUNO. Esculturas. Para Goeldi 1, 1996.

\footnotetext{
${ }^{140}$ Instalação exposta em Casa vermelha, Curitiba, Paraná.

${ }^{141}$ Mostra $4^{a}$ paralela, Liceu de Artes e Ofícios, São Paulo, 2008
} 

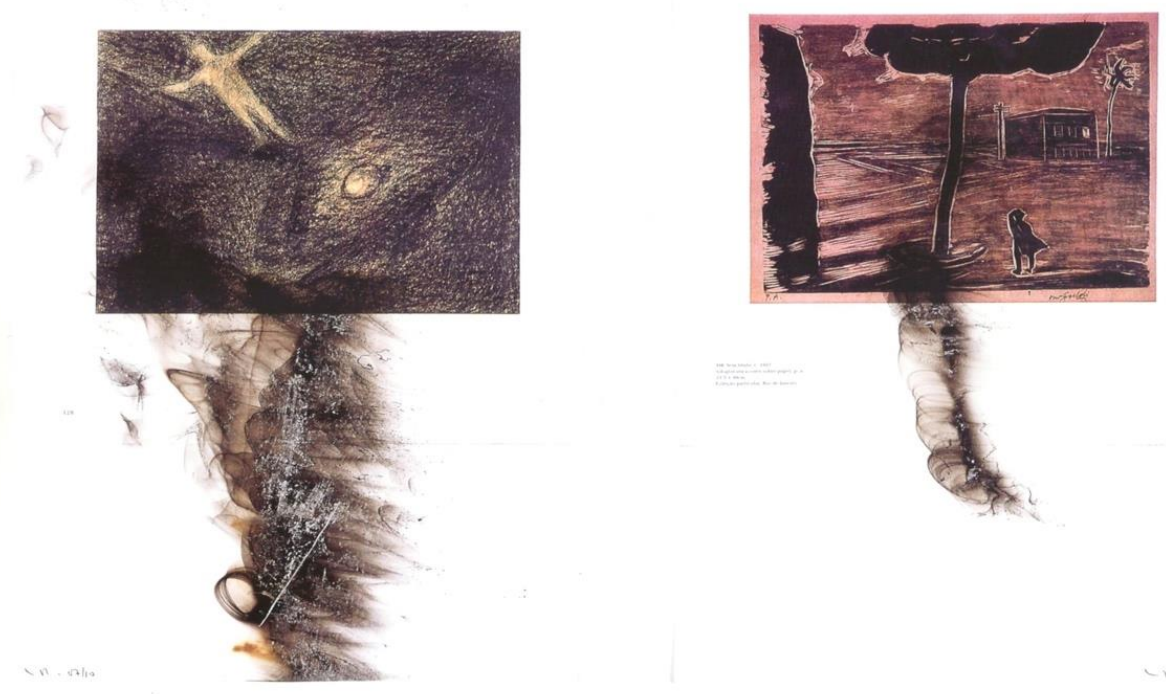

Figura 55: RAMOS, NUNO. Cópias de xilogravuras com intervenção de fumaça. Para Goeldi 1, 1996.

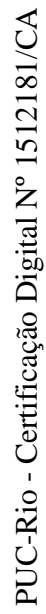

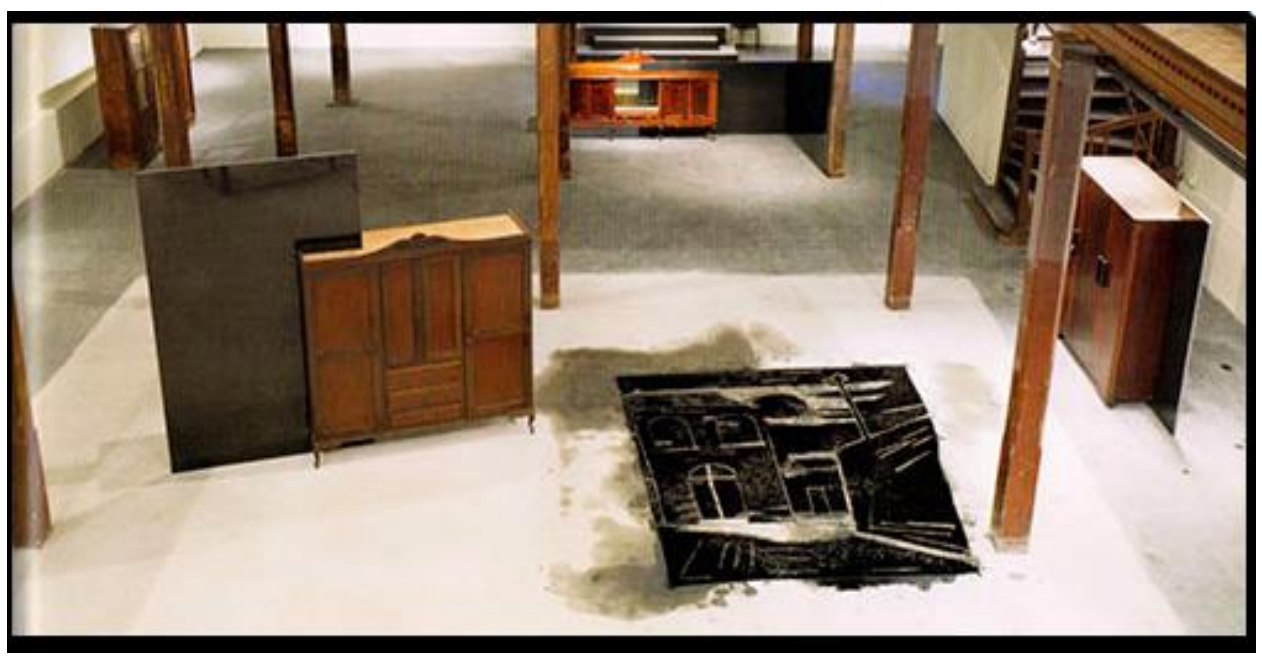

Figura 56: RAMOS, NUNO. Para Goeldi 2, 2000. 


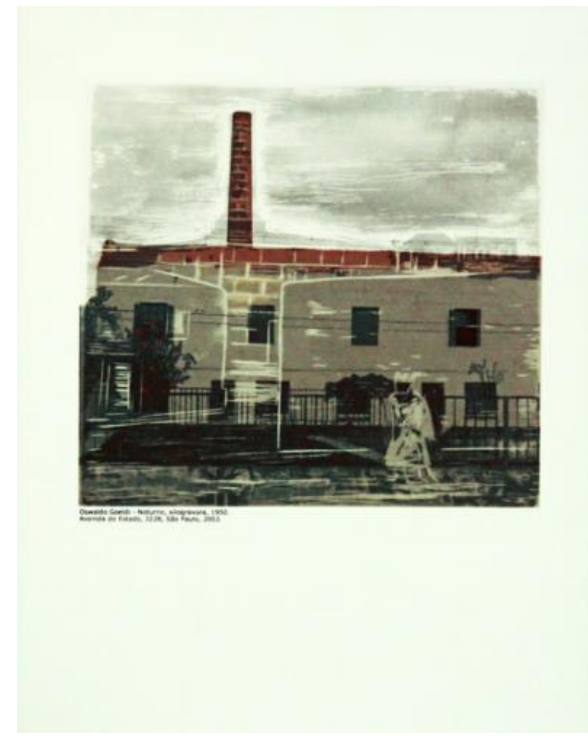

Figura 57: RAMOS, NUNO. Mocambos: Para Goeldi 3, 2003. Serigrafia sobre papel.

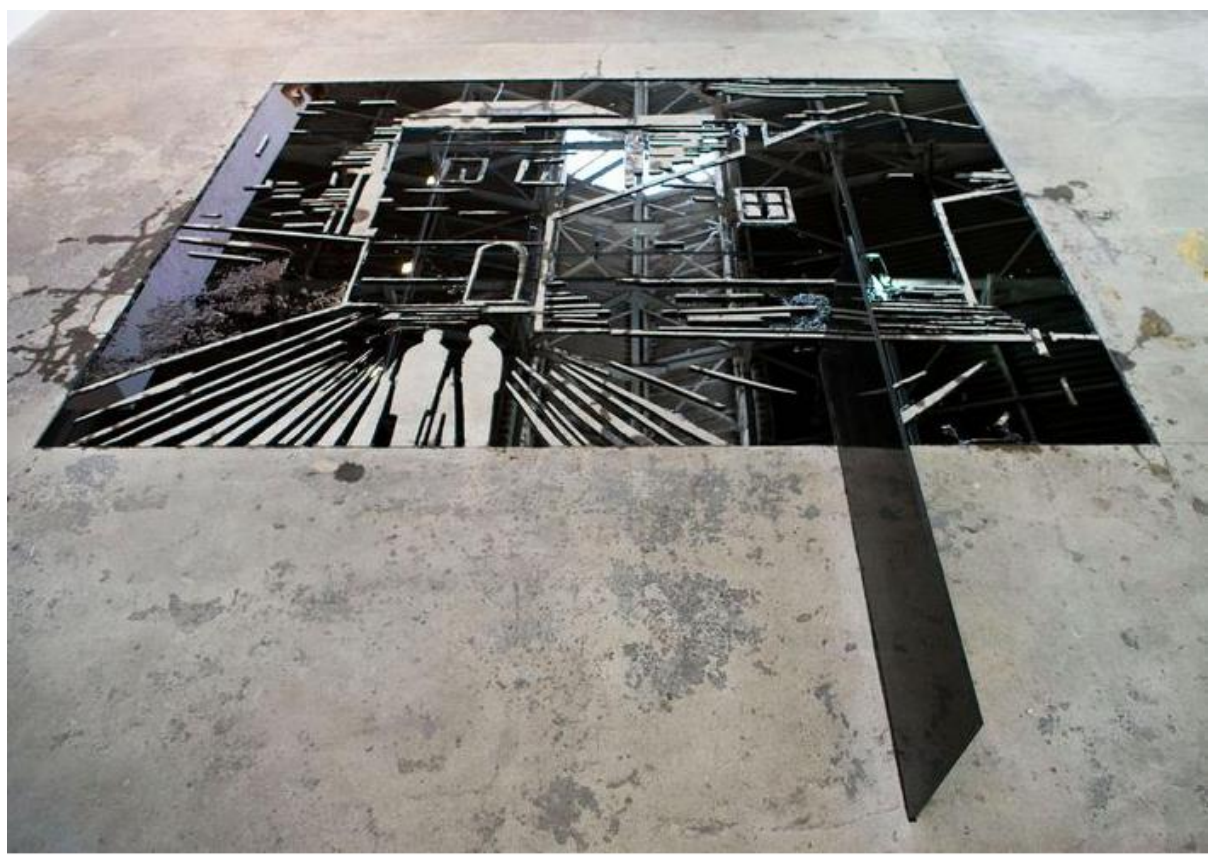

Figura 58: RAMOS, NUNO. Silêncio: Para Goeldi 4, 2008. 


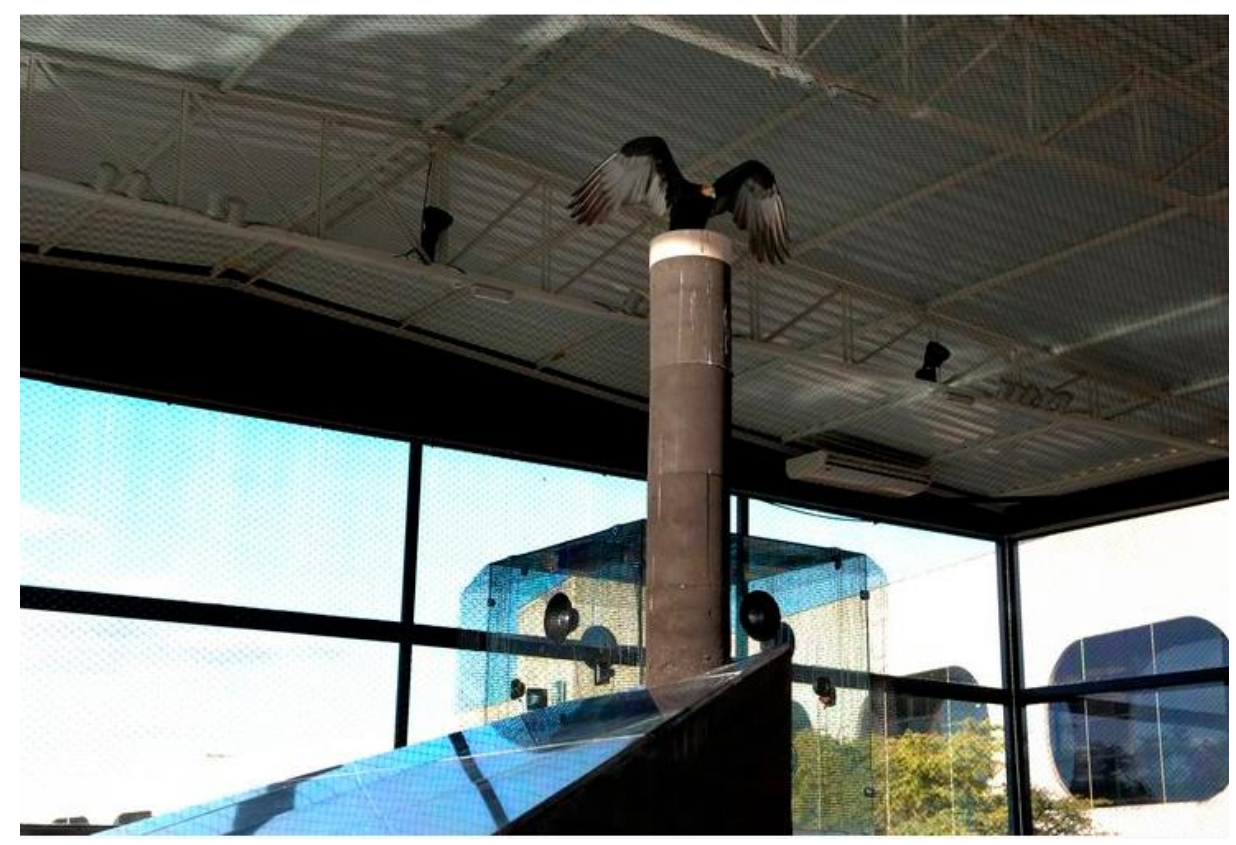

Figura 59: RAMOS, NUNO. Bandeira Branca, 2008.

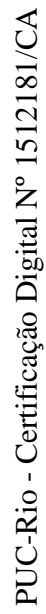

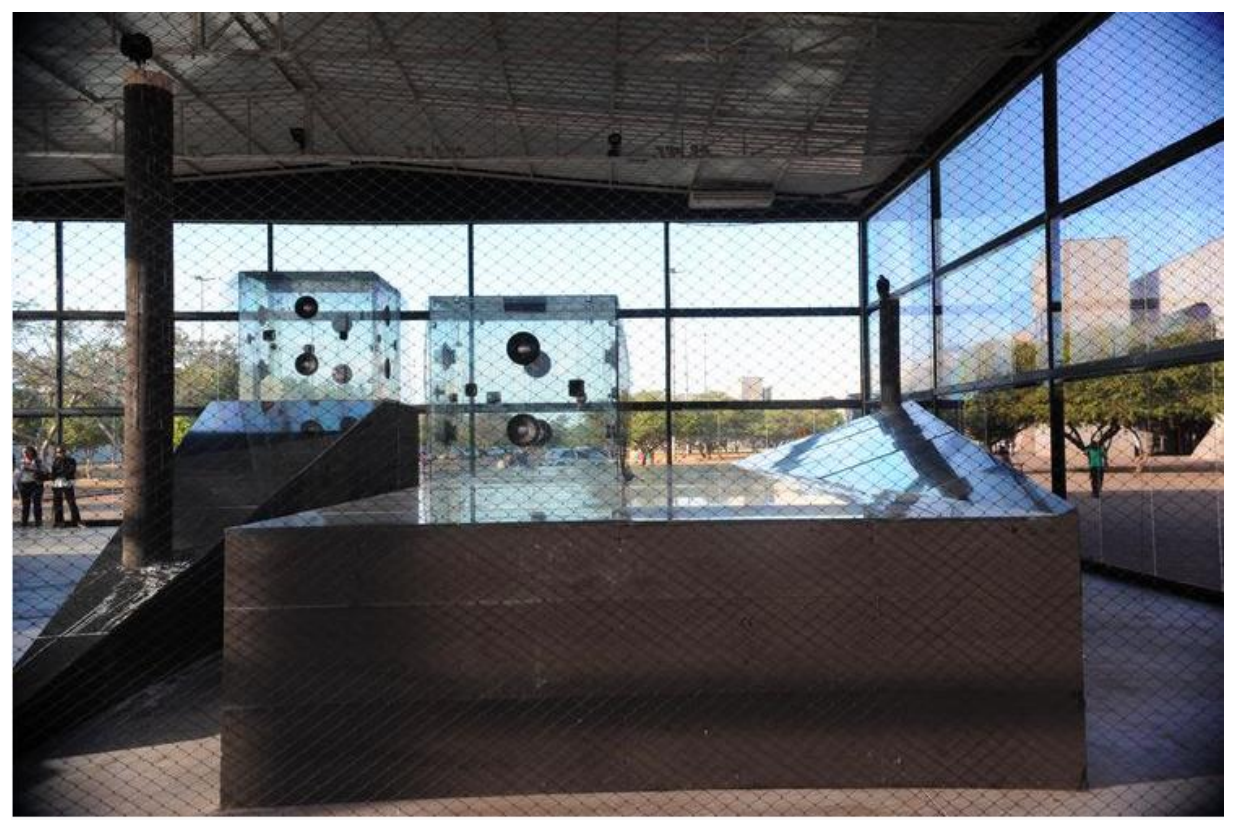

Figura 60: RAMOS, NUNO. Bandeira Branca, 2008. 


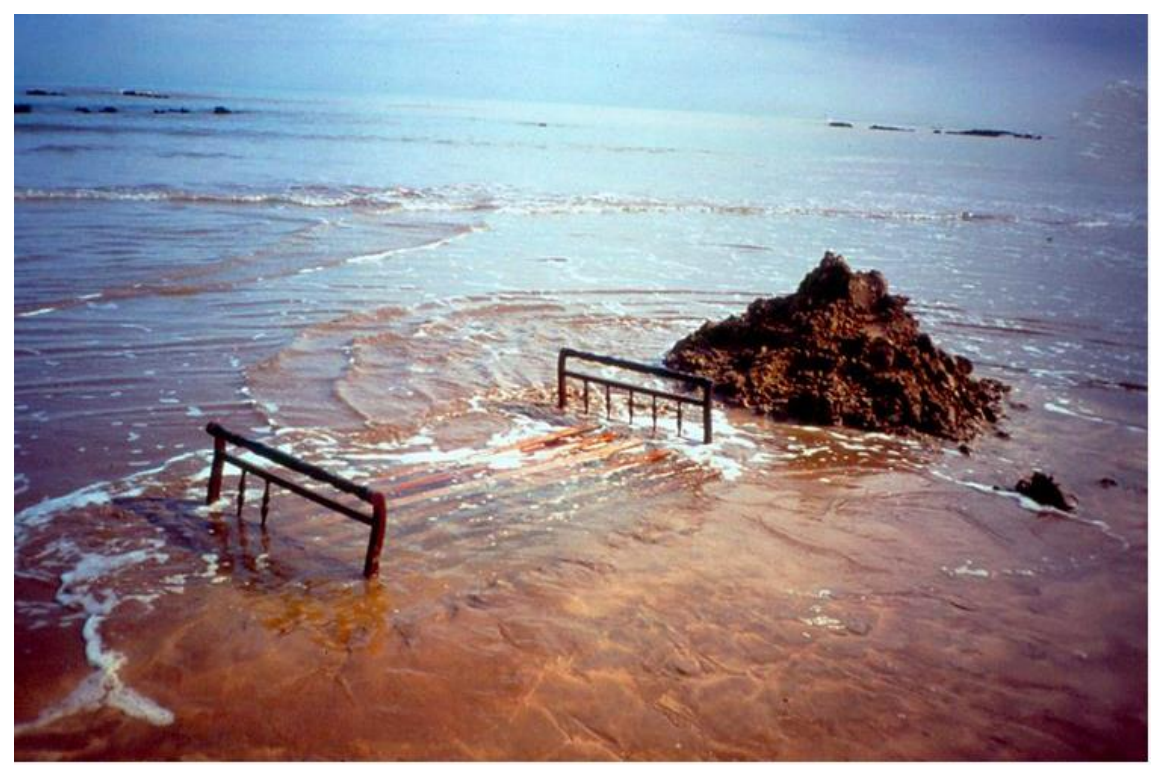

Figura 61: RAMOS, NUNO. Marémobília, 2000.

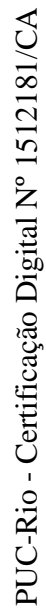

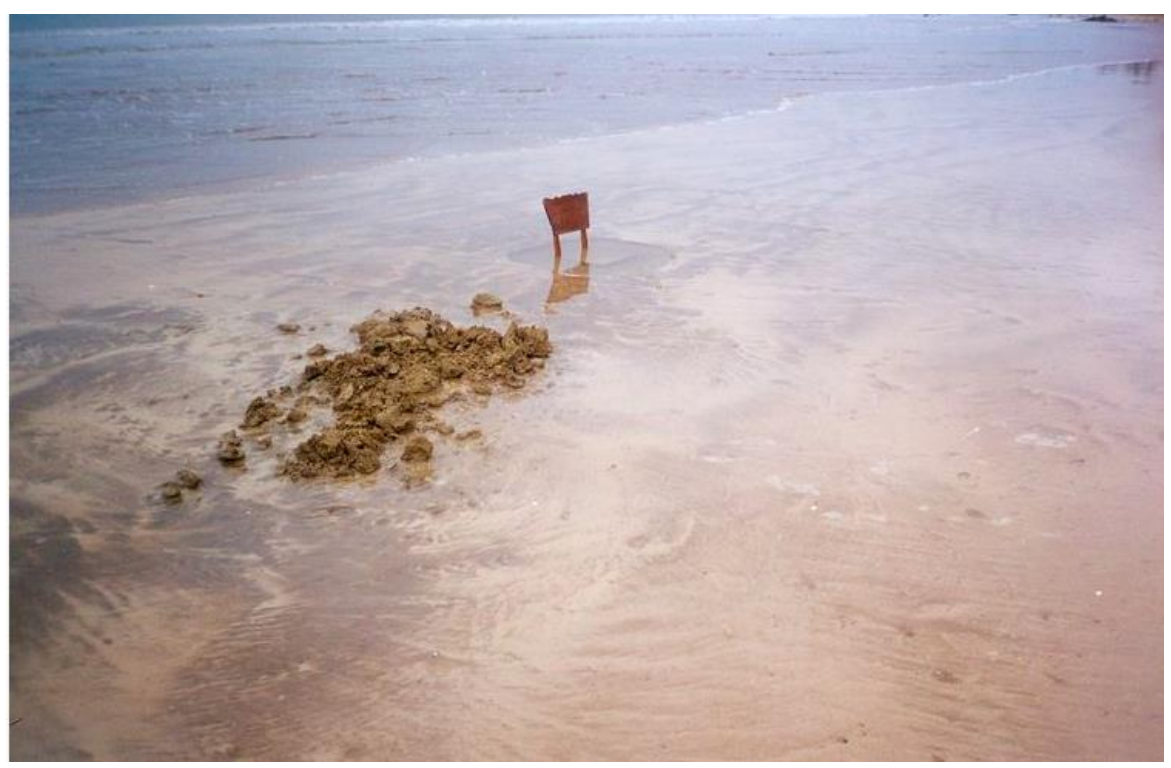

Figura 62: RAMOS, NUNO. Marémobília, 2000. 
Em uma relação mais indireta com Goeldi, em Bandeira Branca (Figs. 59 e $60)^{142}$, também de 2008, exibiu instalação com três esculturas em granito e areia queimada, três postes, três urubus vivos, três caixas de som reproduzindo três músicas que falam de temas como saudade, medo e as maldades de um carcará. A presença dos postes e dos urubus voando pelo espaço, mais uma vez, remetem a ideia da caótica cena urbana e do "agouro sistemático" a espera da morte próxima, presentes na obra do gravurista. Da mesma forma em Marémobília (Figs. 61 e $62)^{143}$, de 2000, a relação entre os dois é inevitável na instalação de nove móveis colocados em buracos com profundidades diversas, com a subida da maré as covas eram inundadas e o que sobravam acima do nível do mar eram fragmentos dos móveis, como que abandonados na praia. Assim como em Goeldi, os objetos perdem a utilidade, "vivem uma vida póstuma e alusiva" e tornam-se "personagens" 144 .

Ao se afastar do comprometimento político, Goeldi concentrou-se no questionamento existencial, optando por uma arte de síntese, na economia de meios tanto como opção estética quanto pessoal. Situou-se em um ponto de interseção emocional entre duas realidades, afastado, em parte, tanto das questões culturais brasileiras quanto das europeias. Neste lugar imaginário, desenvolveu a sua singularidade híbrida. No isolamento e na solidão de seu exílio voluntário, desviou-se da expressão simbólica de Kubin e dos artistas expressionistas reencontrando-se com a gravura romântica nos ambientes suburbanos cariocas, na simplicidade dos pescadores e na noite boêmia, na conciliação entre arte e vida. Isolou-se, permanecendo fiel a si mesmo, seguro de sua poética.

Os desenhos e gravuras de Oswaldo Goeldi representam as primeiras manifestações plásticas autônomas e universais de um Eu moderno brasileiro ${ }^{145}$. Se o projeto modernista procurou nacionalizar a cultura europeia "antropofagicamente", Goeldi concebeu no próprio ambiente vivo, local e concreto, sua dimensão universal: ${ }^{146}$

\footnotetext{
${ }^{142}$ Instalação exposta no Centro Cultural Banco do Brasil, Brasília, DF.

${ }^{143}$ Instalação montada em Nova Almeida, Espírito Santo.

${ }^{144}$ MACHADO, Anibal M. Goeldi. Coleção Artistas Brasileiros. P.13.

145 BRITO, Ronaldo. Oswaldo Goeldi, nossa sombra. Coordenação Silvia Roesler. P.14.

${ }^{146}$ ZÍLIO, Carlos. O outro do modernismo. Oswaldo Goeldi. P.9.
} 
"O que fica definitivamente marcado na produção de Goeldi, contrariamente ao "progressismo modernista", é uma retomada do passado como uma volta que, diferentemente do que será a antropofagia oswaldiana, não descarta o "fora do lugar", não tenta a superação pela negação do conflito, levando à compreensão de outra questão colocada por sua obra, qual seja a da retomada que não passa pela utopia fácil dos sonhos de um "paraíso". Há em Goeldi uma volta que, sem dúvida, aponta para o futuro, mas que passa inevitavelmente pela miserabilidade a que estamos condenados, seja pessoalmente, seja coletivamente. ${ }^{147,}$

E tal volta se reprocessa continuamente. Retornando aos conceitos de paralaxe e a posteriori, percebemos que a atualidade da obra de Goeldi reside exatamente na singularidade. Esta só se torna compreensível, em profundidade, pelo olhar contemporâneo (paralaxe), afastado das ideologias dominantes pelas quais o pensamento no campo das artes visuais se manifestava na primeira metade do século XX. E a legitimação do papel transfigurador desse nosso artista moderno se efetiva, a posteriori, quando "recodificado" a partir de retornos e releituras de seu trabalho por poéticas tão diversas como as que acabamos de analisar ao final dessa dissertação.

${ }^{147}$ CABO, Sheila. Goeldi, modernidade extraviada. P.101. 


\section{Referências bibliográficas}

ABREU, Laura Maria Neves de. Oswaldo Goeldi: desenhos, matrizes e gravuras. Acervo do Museu Nacional de Belas Artes. Rio de Janeiro: Museu Nacional de Belas Artes, 2008.

ANDRADE, Carlos Drummond de. Carlos Drummond de Andrade: poesia e prosa. $8^{\text {a }}$ edição. Rio de Janeiro: Nova Aguilar, 1992.

$04 / 10 / 1956$.

Goeldi e espanto, Correio da Manhã, Rio de Janeiro,

2012.

Sentimento do mundo. São Paulo: Companhia das Letras,

ARGAN, Giulio Carlo. A Arte Moderna na Europa: de Hogarth a Picasso. São Paulo: Companhia das Letras, 1993.

A História da Arte como história da cidade. $1^{\mathrm{a}}$ edição, $1^{\mathrm{a}}$ reimpressão. São Paulo: Martins Fontes, 1993.

1992.

Arte Moderna. $1^{a}$ edição. São Paulo: Companhia das Letras,

AVILA, Affonso (Org.). O Modernismo. $3^{\text {a }}$ edição, 1 reimpressão. São Paulo: Perspectiva, 2013.

BACHELARD, Gaston. A água e os sonhos, ensaio sobre a imaginação da matéria. São Paulo: Editora WMF Martins Fontes, 2013.

A terra e os devaneios da vontade: ensaio sobre a imaginação das forças. $4^{\mathrm{a}}$ edição. São Paulo: Editora WMF Martins Fontes, 2013.

Poética do devaneio. Campinas, SP: Versus Editora, 2010.

Poética do espaço. Rio de Janeiro: Bertrand Brasil, 1994.

BANDEIRA, Manuel. Canção do vento e da minha vida. Lira dos Cinquent'anos. São Paulo: Global Editora, 2013

BARBOSA, Elyana; BULCÃO, Marly. Bachelard: pedagogia da razão, pedagogia da imaginação. $2^{\mathrm{a}}$ edição. Petrópolis, RJ: Editora Vozes, 2011.

BAUDELAIRE, Charles. As flores do mal. $2^{a}$ edição. Edição bilíngue. Rio de Janeiro: Nova Fronteira, 2006.

Curiosités esthétiques: Salon de 1845-1859. Michael Levi Fréres, Libraires Éditeur: $1868 . \quad$ Disponível em $<$ https://archive.org/stream/curiositsesthti00baudgoog\#page/n24/mode/2up>. 
BAUDELAIRE, Charles. Sobre a modernidade. $1^{\text {a }}$ edição. Rio de Janeiro: Paz e Terra, 1996.

BELTING, Hans. O fim da história da arte: uma revisão dez anos depois. $1^{\text {a }}$ edição Cosac Naify Portátil. $1^{\mathrm{a}}$ reimpressão. São Paulo: Cosac Naify Portátil, 2014.

BENJAMIN, Walter. A obra de arte na era da sua reprodutibilidade técnica. Magia e técnica, arte e política: ensaios sobre literatura e história da Cultura, $8^{\mathrm{a}}$ Edição, $1^{\text {a }}$ reimpressão. São Paulo: Brasiliense, 2012 (Obras Escolhidas Vol.I).

Editora, 2015.

Baudelaire e a modernidade. Belo Horizonte: Autêntica

BRITO, Ronaldo. A semana de 22: o trauma moderno. Sete ensaios sobre o modernismo. Caderno de textos 3. Rio de Janeiro: Funarte, 1983.

Goeldi, o brilho da sombra. A experiência crítica. $1^{\text {a }}$ edição. São Paulo: Cosac \& Naify, 2005.

Oswaldo Goeldi, Chuva. Rio de Janeiro: IMS, 2011. https://blogdoims.com.br/oswaldo-goeldi-chuva-por-ronaldo-brito.

. Oswaldo Goeldi, nossa Sombra. Goeldi. $1^{\text {a }}$ edição. Coordenação de Silvia Roesler. Rio de Janeiro: Instituto Cultural The Axis, 2002.

CABO, Sheila. A utopia expressionista de Kandinsky. Revista Arte \& Ensaios. EBA-UFRJ, 2007. Disponível em:<http://www.ppgav.eba.ufrj.br/wpcontent/uploads/2012/01/ae15_Sheila_Geraldo.pdf>.

Goeldi, modernidade extraviada. Rio de Janeiro: Adesa, 1987.

CAPISTRANO, Tadeu. org. Benjamin e a obra de arte. Rio de Janeiro: Contraponto, 2012.

CASTRO, Felipe Süssekind Viveiros de. Cor gráfica: a experiência cromática na obra de Goeldi. Dissertação de Mestrado. Rio de Janeiro: PUC-Rio, 2000.

FOSTER, Hal. O retorno do real: a vanguarda no final do século XX. São Paulo: Cosac Naify, 2014.

GUINSBURG, J, (Org.). O Romantismo. $2^{\mathrm{a}}$ reimpressão da $4^{\mathrm{a}}$ edição de 2002. São Paulo: Perspectiva, 2011.

GULLAR, Ferreira. Goeldi e fulgor da noite. Relâmpagos (dizer o ver). $2^{\mathrm{a}}$ edição. São Paulo: Cosac \& Naify, 2007.

KANDISKY, Wassily. O efeito da cor. In: Chipp, Herschel B. (Org.), Teorias da arte moderna. $2^{a}$ Edição. Rio de Janeiro: Martins Fontes, 1996. 
LOYD, Jill. Van Gogh and Munch: a question of style. Munch: Van Gogh Exposition Catalogue. Amsterdam: Van Gogh Museum, 2015.

MACHADO, Aníbal M. Goeldi. Coleção Artistas Brasileiros. Rio de Janeiro: Ministério da Educação e Cultura (MEC).

MARQUES, Maria Eduarda Castro Magalhães. Goeldi e a cena urbana moderna: solidão e melancolia. Revista Gávea, vol. 6, dezembro de 1988.

MATTOS, Claudia Valadão de. Expressionismo alemão, arte e vida. In: Almeida, Jorge e Wolfgang, Bader (Orgs.). Pensamento Alemão no século XX: grandes protagonistas e recepção das obras no Brasil, volume III. São Paulo: Cosac \& Naify, 2013.

MELLO, Cecilia Cotrim Martins de. Goeldi e Iberê: Romantismo e Atualidade. Revista Gávea. Rio de Janeiro: Pontifícia Universidade Católica do Rio de Janeiro, 1991.

MERLEAU-PONTY, Maurice. Fenomenologia da Percepção. 4a edição. São Paulo: Editora WMF Martins Fontes, 2011.

NAVES, Rodrigo. A forma difícil: ensaios sobre a arte brasileira. São Paulo: Companhia das Letras, 2011.

Edições, 1999.

Goeldi. Espaços da arte brasileira. São Paulo: Cosac \& Naify

NOLDE, Emil. Emil Nolde, anos de luta. In: Chipp, H.B (org.). As teorias da arte moderna. Rio de Janeiro: Martins Fontes, 1988.

OSÓRIO, Luiz Camillo. Lygia Pape: Experimentação e resistência. Olhar à margem: caminhos da arte brasileira. São Paulo: Editora Sesi-SP e Cosac Naify, 2016.

PEDROSA, Mario. Arte Ensaios: Mario Pedrosa. Organização Lorenzo Mammì. São Paulo: Cosac Naify, 2015.

PEDROSA, Mario. Dos Murais de Portinari aos espaços de Brasília. Organização Aracy A. Amaral. Rio de Janeiro: Perspectiva, 1981.

QUEIROZ, Raquel de. Exposição de gravuras. Jornal Folha Carioca, Rio de Janeiro, 01/07/1944.

RAMOS, Nuno. Noite morta. Catálogo da exposição Noite Morta: Manuel Bandeira e Oswaldo Goeldi. São Paulo: Caixa Cultural, 1994.

REIS JÚNIOR, José Maria dos. Goeldi. Rio de Janeiro: Civilização Brasileira, 1966. 
RIBEIRO, Noemi. Oswaldo Goeldi na coleção Hermann Kümmerly. Rio de Janeiro: Papel \& Tinta, 2005.

Oswaldo Goeldi: mestre visionário. São Paulo: SESI, 1996.

Oswaldo Goeldi: um autorretrato. São Paulo: SESI, 1996.

RIO, João do. A alma encantadora das ruas: crônicas. Organização Raúl Antelo. São Paulo: Companhia das Letras, 2008.

RODRIGUES, Antonio Edmilson Martins. Em algum lugar do passado: cultura e história da cidade do Rio de Janeiro. In: AZEVEDO, André Nunes de (org.). Rio de Janeiro - capital e capitalidade. Rio de Janeiro: Depto. Cultural/NAPE/UERJ, 2002.

João do Rio: a cidade e o poeta - o olhar de flâneur na Belle Époque Tropical. Rio de Janeiro: Editora FGV, 2000.

RUFINONI, Priscila Rossinetti. Oswaldo Goeldi, iluminação, ilustração. São Paulo: Cosac e Naify e Fapesp, 2006.

SARDENBERG, Ricardo (ORG.). Nuno Ramos. Texto crítico de arte de Alberto Tassinari. Rio de Janeiro: Editora Cobogó, 2010.

SHAPIRO, Meyer. A Arte Moderna: Séculos XIX e XX. Ensaios escolhidos. São Paulo: Editora da Universidade de São Paulo (EDUSP), 2010.

SHINER, Larry. The Invention of Art: a cultural history. Chicago: The University of Chicago Press, 2001.

SIQUEIRA, Vera Beatriz. Cálculo da Expressão. Catálogo da exposição: Cálculo da Expressão, Goeldi, Segall e Iberê. Porto Alegre: Fundação Iberê Camargo, 2009.

Olhares contaminados: leituras de Oswaldo Goeldi. IV EHA

- Encontro de História da Arte. Unicamp, 2010. Disponível em:<http://www.unicamp.br/chaa/eha/atas/2010/vera_beatriz_siqueira.pdf >.

SYLVESTER, David. Sobre a arte moderna. São Paulo: Cosac Naify, 2006.

TODOROV, Tzvetan. Goya, à sombra das luzes. São Paulo: Companhia das Letras, 2014.

VENÂNCIO FILHO, Paulo. Goeldi: um expressionista nos trópicos. Revista Novos Estudos - CEBRAP. Edição 40, vol.III, novembro de 1994. Disponível em:<http://novosestudos.uol.com.br/produto/edicao-40/ - 59154c725707a>.

Oswaldo Goeldi: sombria luz (Shady Light). São Paulo: Museu de Arte Moderna de São Paulo, 2012. 
ZILIO, Carlos. (Org.) Oswaldo Goeldi. Catálogo Oswaldo Goeldi. Solar Grandjean de Montigny. Rio de Janeiro: PUC-Rio, 1982.

. A querela do Brasil. Rio de Janeiro: FUNARTE, 1982.

A questão política no modernismo In: Fabris, Annatereza

(Orgs.). Modernidade e modernismo no Brasil. Campinas-SP: Mercado de arte, 1994.

$O$ artista modernista enquanto intelectual. In: Kern, Maria

Lúcia Bastos; Bulhões, Maria Amélia (Orgs.). A Semana de 22 e a emergência da modernidade no Brasil. Porto Alegre: Secretaria Municipal de Cultura, 1992. http://www.carloszilio.com/textos/1992-artista-moderno-enquanto-intelectual.pdf.

\section{OUTROS CATÁLOGOS DE EXPOSIÇÕES}

A gravura de Lasar Segall. São Paulo: Museu Lasar Segall, 1988.

Goeldi e nosso tempo. São Paulo: Museu de Arte Brasileira da Fundação Armando Álvares Penteado (FAAP), 1995.

Goeldi: Luz Noturna. São Paulo: Caixa Cultural, 2009.

Impressões originais: a gravura desde o século XV. São Paulo: Art Unlimited, 2006.

Matrizes do Expressionismo no Brasil: Abramo, Goeldi e Segall. São Paulo: Museu de Arte Moderna de São Paulo, 2000.

Visões de guerra. São Paulo: Museu Lasar Segall, 1988.

\section{ENTREVISTAS}

Entrevista de Lygia Pape a Frederico Morais. O Globo. Rio de Janeiro, 22/07/1975.

Entrevista de Lygia Pape à Paulo Venâncio Filho, Glória Ferreira e Ronald Duarte. Dossiê Lygia Pape. Revista Arte \& Ensaios. EBA-UFRJ, 19/08/1998. Disponível em: <http://www.ppgav.eba.ufrj.br/wpcontent/uploads/2012/01/Dossi\%C3\%AA-Lygia-Pape-Entrevista-de-Lygia-Papea-Paulo-Venancio-Filho-Gl\%C3\%B3ria-Ferreira-e-Ronald-Duarte.pdf>. 
Entrevista de Oswaldo Goeldi a Anna Letycia. Revista Paratodos, setembro de 1956. In: ZÍLIO, CARLOS (Org.). Oswaldo Goeldi. Solar Grandjean de Montigny, PUC-Rio.

Entrevista de Oswaldo Goeldi a Ferreira Gullar. Suplemento Dominical do Jornal do Brasil, em 12/01/1957. In: BRITO, RONALDO. Oswaldo Goeldi, $1^{\text {a }}$ edição. Coordenação de Silvia Roesler. Rio de Janeiro: Instituto Cultural The Axis, 2002.

\section{OUTROS ARTIGOS ACADÊMICOS ON-LINE}

KRASSUSKI, LÍVIA. A expressão simbólica de Gauguin: o sintetismo. Abra, 2008. Disponível em: $<\mathrm{http}: / / \mathrm{www}$.abra.com.br/artigos/13-a-expressao-simbolica-degauguin-o-sintetismo>

WINCKELMANN, Johann Joachim. Préface. In Histoire de l'Art chez les Anciens, tome I. Yverdon: 1784. P.V-XXXIV. Tradução: Daniela Kern Disponível em: <https://lume-redemonstracao.ufrgs.br/fontesprimarias/pdf/winckelmann.pdf 